\title{
Influence of sward height, daily timing of concentrate supplementation and grazing time management on pasture utilization of lactating beef cows
}

\author{
Ondieki James Gekara \\ West Virginia University
}

Follow this and additional works at: https://researchrepository.wvu.edu/etd

\section{Recommended Citation}

Gekara, Ondieki James, "Influence of sward height, daily timing of concentrate supplementation and grazing time management on pasture utilization of lactating beef cows" (2003). Graduate Theses, Dissertations, and Problem Reports. 1950.

https://researchrepository.wvu.edu/etd/1950

This Dissertation is protected by copyright and/or related rights. It has been brought to you by the The Research Repository @ WVU with permission from the rights-holder(s). You are free to use this Dissertation in any way that is permitted by the copyright and related rights legislation that applies to your use. For other uses you must obtain permission from the rights-holder(s) directly, unless additional rights are indicated by a Creative Commons license in the record and/ or on the work itself. This Dissertation has been accepted for inclusion in WVU Graduate Theses, Dissertations, and Problem Reports collection by an authorized administrator of The Research Repository @ WVU.

For more information, please contact researchrepository@mail.wvu.edu. 


\title{
Influence of Sward Height, Daily Timing of Concentrate Supplementation and Grazing Time Management on Pasture Utilization of Lactating Beef Cows
}

Ondieki James Gekara

Dissertation submitted to the

Davis College of Agriculture, Forestry and Consumer Sciences

West Virginia University

In partial fulfillment of the requirements

For the degree of

\section{Doctor of Philosophy \\ In \\ Animal and Food Sciences}

\author{
Edward C. Prigge, Ph.D., Chair \\ William H. Hoover, Ph.D. \\ P. Brett Kenney, Ph.D. \\ Kenneth P. Blemings, Ph.D. \\ ${ }^{1}$ William B. Bryan, Ph.D.
}

Division of Animal and Veterinary Sciences

${ }^{1}$ Division of Plant and Soil Sciences

\author{
Morgantown, West Virginia \\ 2003
}

Keywords: Sward Height, Supplementation, Management, Cows, Intake, Digestibility

Copyright 2003 Ondieki J. Gekara 


\title{
ABSTRACT \\ Influence of Sward Height, Daily Timing of Concentrate Supplementation and Grazing Time Management on Pasture Utilization of Lactating Beef Cows
}

\author{
Ondieki J. Gekara
}

To establish the effect of sward height, concentrate feeding time and grazing time management on performance of grazing cattle, thirty-two cross-bred beef (24 Angus and 8 Hereford) cows (632 kg BW) and calves (104 kg BW) were grouped by weight and calving date. They were randomly assigned to two sward height ( $\mathrm{SH}$ ) treatments (4 to 8 or 8 to $12 \mathrm{~cm}$ ), replicated four times. The cows were fed a concentrate supplement $\left(4.1 \mathrm{~kg} \mathrm{DM} \cdot \mathrm{cow}^{-1} \cdot \mathrm{d}^{-1}\right)$ in the AM at $0700 \mathrm{~h}$ or PM at $1800 \mathrm{~h}(\mathrm{~T})$, and either restricted to $12 \mathrm{~h} / \mathrm{d}$ grazing (0700 to $1900 \mathrm{~h}$ ) or unrestricted to $24 \mathrm{~h} / \mathrm{d}$ grazing (MGT). The experiment was repeated over three 15-d periods in May, June/July and August 2000. The herbage on high SH pasture was higher $(P<.05)$ in fiber and lower $(P<.01)$ in crude protein compared to low $\mathrm{SH}$ herbage. For cows on restricted grazing, supplementing in the AM as opposed to PM resulted in greater $(P<.05)$ forage DMI $(8.6$ vs. $8.1 \mathrm{~kg} / \mathrm{d})$ while unrestricted cows had greater forage DMI ( $8.4 \mathrm{vs} .8 .2 \mathrm{~kg} / \mathrm{d})$ when supplemented in the PM as opposed to AM. Supplementing in the PM as opposed to AM resulted in greater $(P<.05)$ herbage DMD $(67.7$ vs. $65.4 \%)$ for cows on high SH; cows on low SH had greater herbage DMD (66.3 vs. 64.5\%) when supplemented in the AM. An interaction between T and MGT $(P<.10)$ for digestible DMI (DDMI) was apparent. For cows restricted to $12 \mathrm{~h} / \mathrm{d}$ grazing, supplementing in the AM as opposed to PM resulted in greater DDMI (5.0 vs. $4.7 \mathrm{~kg} / \mathrm{d}$ ) while unrestricted cows had greater DDMI (4.9 vs. $4.6 \mathrm{~kg} / \mathrm{d}$ ) when supplemented in the PM as opposed to AM. Supplementing in the PM as opposed to AM, increased the time spent grazing $(P<.10)$ to a greater extent for restricted compared to unrestricted cows. When forage availability or grazing time is limiting, supplementing in the AM may result in greater forage utilization because of increased forage DMD and DDMI. 


\section{ACKNOWLEDGEMENTS}

I would like to express my sincere thanks to the Division of Animal and Veterinary Sciences, West Virginia University for financial and material support during my graduate studies. I was very privileged to work with Dr. Edward C. Prigge who served as the chairman of my graduate committee as well as my advisor as an undergraduate student. Dr. Prigge was generous enough to help with fieldwork and every step during the development of this document. I wish to thank Dr. William H. Hoover, Dr. William B. Bryan, Dr. P. Brett Kenney, and Dr. Kenneth Blemings for their willingness to serve in my graduate committee. I thank Drs. W. V. Thayne and George Seidel for their help with experimental design and statistical analyses.

I wish to thank Eric Nestor for his help with fieldwork and lab procedures and Tammy Miller for her help with protein, fiber and $\mathrm{Yb}$ analyses. I deeply appreciate the help of Marcella Schetini and Chuck Wolfe (graduate students), Heather Clemmer, John Abersold, Adam Dobbins, Sheila Adams, Stacey Hawkins, and Pius Cheserek (work study) with fieldwork and lab. Last but not least, I would like to thank my children (Acline, Albert and Annette) and my parents for their understanding and encouragement as I completed this program. 


\section{TABLE OF CONTENTS}

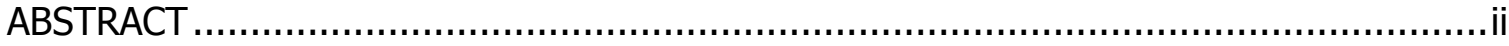

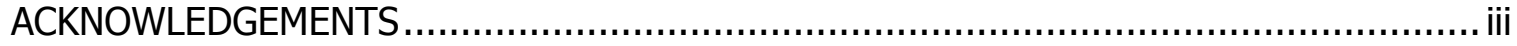

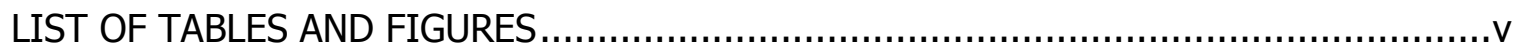

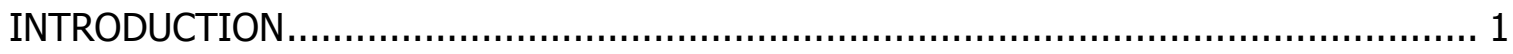

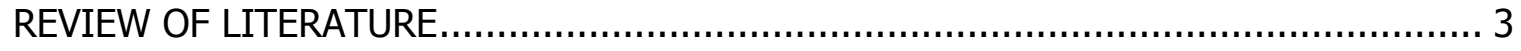

Factors Influencing Forage Utilization by Grazing Animals ...................................... 3

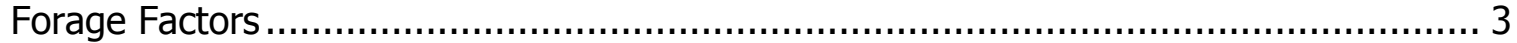

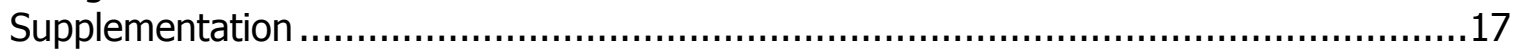

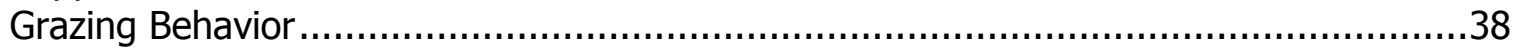

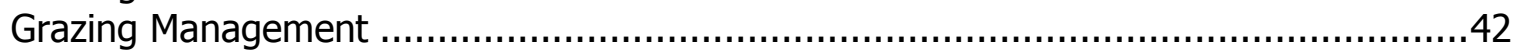

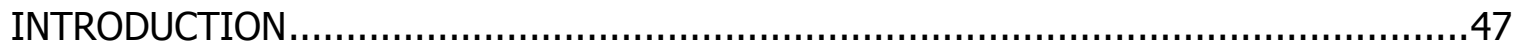

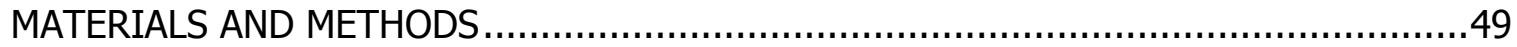

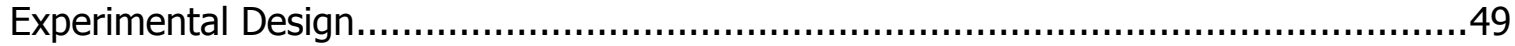

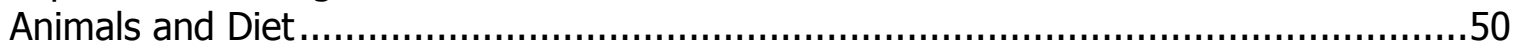

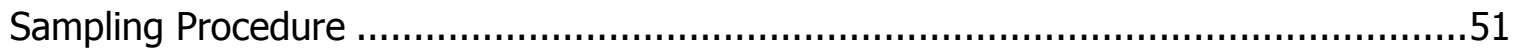

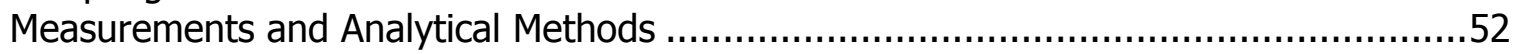

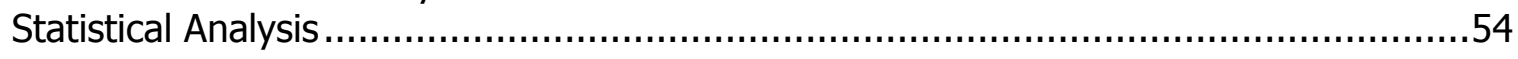

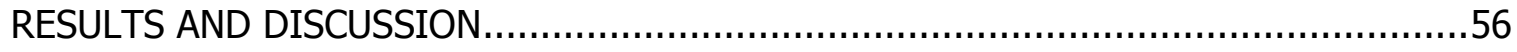

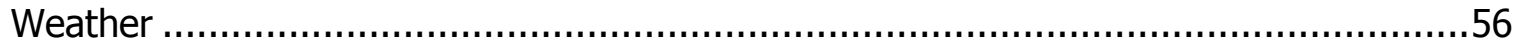

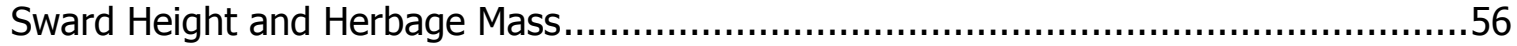

Botanical and Chemical Composition of Pasture...................................................57

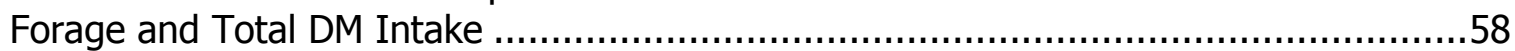

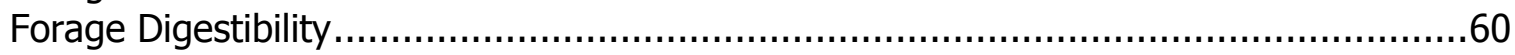

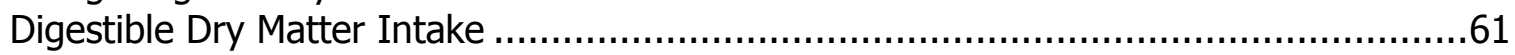

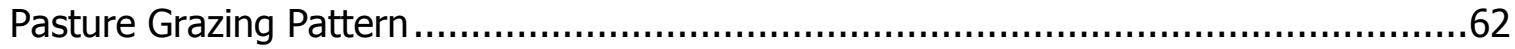

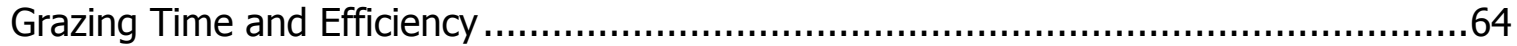

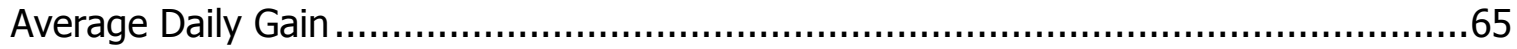

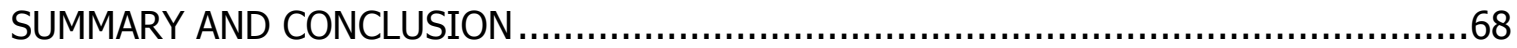

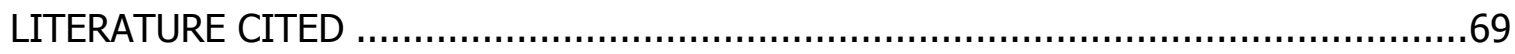

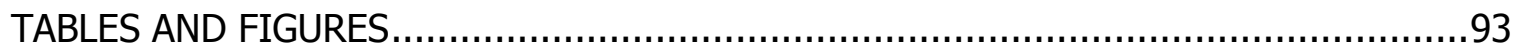

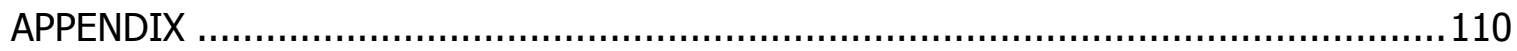

VITA 


\section{LIST OF TABLES AND FIGURES}

Table

Page

1 Composition and nutrient content of concentrate supplement.................93

2 Mean weekly maximum and minimum temperature and precipitation ........94

3 Influence of sward height on botanical composition of forage ..................95

4 Influence of period on botanical composition of forage .........................96

5 Influence of sward height on chemical composition of forage .................97

6 Influence of period on chemical composition of forage ...........................98

Figure

1 Influence of sward height and period on proportion of grass ...................99

2 Influence of sward height and period on proportion of dead material ......100

3 Influence of supp feeding time and management on forage DMI ............101

4 Influence of sward height and supp feeding time on forage DMD............102

5 Influence of supp feeding time and management on dig forage DMI ....... 103

6 Influence of supp feeding time and management on GT ......................104

7 Influence of supp feeding time and management on GE......................105

8 Influence of sward height and period on GT ....................................106

9 Influence of management and hour on grazing pattern .......................107

10 Influence of sward height and hour on grazing pattern ...................... 108

11 Influence of sward height and supp feeding time on ADG (cows) ............109 


\section{CHAPTER 1: INTRODUCTION}

In the US, lactating dairy and finishing beef cattle are fed high levels of concentrates such as corn and soybean meal because of the desire for greater levels of productivity. When cattle consume forages as their only feed source, intake of available energy may not be adequate to meet desired rates of performance (gestation, lactation, and gain). Supplementation with concentrate feeds has the potential to increase the production level of cattle on pasture. However, supplementation of grazing cattle with concentrates has not always been a viable option to increase animal performance.

Previous work (Gekara et al., 2001) has shown that forage utilization decreased as level of supplement increased (to greater than $60 \%$ of total DMI) and season progressed (spring to late summer). The decrease in forage utilization could be attributed to forage conditions, associative animal factors and/or rumen environment. Forage factors influencing forage utilization include botanical and chemical composition (Minson, 1990), physiological maturity (Hodgson, 1990), cell wall characteristics (Akin, 1989; Jung, 1989), forage allowance (Hodgson, 1975, 1984), and forage height and density (Jamieson and Hodgson, 1979). Animal factors such as bite size, biting rate, grazing time and selectivity (Hodgson, 1990; Rook et al., 1994a) also exert great influence on

forage utilization. To increase forage utilization further, an optimum environment has to be maintained in the rumen (Hoover, 1986; Mould and 
Ørskov, 1984). For efficient nutrient utilization, grazing management should minimize animal and forage factors that negatively influence animal performance and forage productivity. 


\section{CHAPTER 2: LITERATURE REVIEW}

\section{Factors influencing forage utilization by grazing animals}

Grazing ruminants derive most of their energy from forage fermented in the rumen. Forage fermentation is the work of a diverse population of anaerobic microorganisms (bacteria, protozoa and fungi) resident in the rumen (Hungate, 1966). Microbial fermentation of plant constituents (structural and non-structural carbohydrates) yields volatile fatty acids (VFA) that provide energy to ruminants. A combination of animal and plant factors interact to affect physical degradation of forages, promoting passage of plant residues through the intestinal tract, thus, influencing forage intake and consequent utilization (Akin, 1989). Protein available for digestion in the small intestine is from undigested protein and microbial protein synthesized in the rumen (Akin, 1989; Van Soest, 1994). To increase forage utilization an optimum environment in the rumen has to be maintained (Hoover, 1986).

\section{Forage factors}

Supply of adequate high quality forage throughout the grazing season and year round is a major challenge for cattle producers worldwide. Forage quality refers to the nutrient content of forage (non-structural carbohydrates, crude protein, neutral detergent fiber, acid detergent fiber, lipids, vitamins and minerals) in regard to digestibility and availability of these nutrients to the host 
animal. Forage quality is influenced by its botanical and chemical composition, and physiological maturity (Minson, 1990) while quantity of grazed forage (mass) is determined by its height and density (Jamieson and Hodgson, 1979). Forage quality and quantity influence forage intake and digestibility and subsequently productivity of grazing animals (Minson, 1990). Forage allowance (forage mass per unit area of pasture available to a population of grazing animals) also influences forage utilization (Hodgson, 1975).

\section{A. Botanical and chemical composition}

Both botanical composition (proportion of grass, legume, weeds and dead material) and chemical composition or nutrient content (dry matter, crude protein, fiber, lignin and ash) can influence forage utilization by grazing ruminants (Minson, 1990).

Botanical composition

Voluntary intake of legumes has been observed to be $28 \%$ greater than equally digestible grasses (Minson, 1971). The higher intake of alfalfa compared with grasses appears to be due to an increased rate of digestion and rate of passage from the rumen of the neutral detergent fiber (NDF) fraction of legumes (Hacker and Minson, 1981; Poppi et al., 1981). Greater intake of legume than grass is partially responsible for the superior performance of ruminants fed legumes (Reid et al., 1990). Ruminal digesta fill is usually less for legume than for grass (Thornton and Minson, 1973) probably due to differences in cell wall composition (Minson, 1990). Effects of legume on intake and animal 
performance is related to enhanced propionate production, increased rate of ruminal outflow of undigested forage (Moseley and Jones, 1979, 1984), elevated ruminal organic matter (OM) digestion rate, and postruminal digestion of protein (Beever et al., 1986a,b). To achieve the same metabolizable energy (ME) utilization, grass must be at least ten percentage units more digestible than legume (Freer and Jones, 1985). Legumes also have a lower water-soluble carbohydrate content and greater buffering capacity, which restricts rapid decline in rumen $\mathrm{pH}$, thus, stabilizing the rumen environment (Minson, 1990).

Moseley and Dellow (1985) reported that the efficiency of use of ME for maintenance or gain is typically greater for legume than grass based diets. Greater concentration of ME in legumes and less energy expended for ingesting and ruminating legumes than grasses are thought to be the reasons. High propionate production may be a major contributor to greater efficiency for legumes than for grasses (Waldo et al., 1990); a high propionate supply minimizes tissue catabolism for gluconeogenesis (Abdul-Razzaq and Bickerstaffe, 1989). Martz et al. (1999) reported that the content of crude protein (CP), net energy for lactation and in situ dry matter (DM) digestibility of cool season pasture increased for dairy cattle during the grazing season. Further, the content of NDF decreased and acid detergent fiber (ADF) tended to remain constant or decreased during the grazing season, probably because of increased legume and decreased amount of dead material in the sward in late summer. 


\section{Chemical composition}

Neutral detergent fiber (hemicellulose, cellulose, lignin, and some ash) is the most consistent fiber component associated with intake (Van Soest, 1994). The negative association of NDF with intake has usually been interpreted as a fill effect (Van Soest, 1994). Similarly, acid detergent fiber (cellulose, lignin, and some Ash) component is negatively associated $(r=-.79)$ with digestibility (Minson, 1990). In addition, acid detergent lignin (lignin and some ash) of forage is negatively correlated with DM and OM digestibility (Van Soest, 1994). When animals consume low quality roughages, protein $(<5 \% \mathrm{CP})$ not only becomes deficient relative to requirements of the host animal, but also limits the supply of degradable proteins for microbial growth and fermentation. Consequently, the rate of cell wall digestion drops dramatically and passage rate decreases as well as forage intake (Hodgson and Illius, 1996). Thus, protein deficiencies are a major limitation to intake and utilization of forages. In wellmanaged temperate grass-legume pastures animal production is rarely limited by digestible proteins, thus, output per animal can be substantially improved by supplementing with high-energy grains (Blaser et al., 1969).

B. Cell wall characteristics

Plant cell walls are the major sources of dietary fiber for animals. Energy availability from forages is limited by fiber concentration (accounts for $30-80 \%$ of OM in forages) because fiber is slowly and incompletely digested whereas cell

solubles are almost completely digested (Buxton and Brasche, 1991; Buxton, 
1996). Mammalian enzymes cannot degrade cell wall polysaccharides; instead, herbivores depend on microbial fermentation to degrade these polysaccharides (Buxton and Brasche, 1991). In the grazing ruminant, intake control is usually dominated by the effect of plant cell wall material in the digestive tract, especially the rate at which digesta can leave the rumen (Kennedy, 1990). The relative effects of mastication, rumination, ease of microbial colonization and rate of enzymatic digestion on particle outflow are mainly influenced by the cell wall characteristics which affect the rate of digesta disappearance from the rumen (Hodgson and Illius, 1996).

Rate and possibly extent of rumen microbial degradation of cell wall carbohydrates $(\mathrm{CHO})$ may vary due to degree of $\mathrm{H}$-bonding, branching patterns, and association of individual $\mathrm{CHO}$ with other cell wall constituents, mainly lignin (Hatfield, 1989). As forage plants mature, increased crystallization of cellulose and bonding between cell wall polysaccharides (cellulose and hemicellulose) and lignin, present a major problem to the ruminant (Akin, 1989). Physical resistance of mature forage to chewing and rumination increases while susceptibility to microbial colonization and digestion is reduced (Dove, 1996). Increasing stem to leaf ratio compounds the effect of maturation in that microbial access during digestion is restricted, since stem usually contains more lignin (Wilson, 1994).

Grass fiber is more digestible than that of legumes (ruminants digest 60$70 \%$ of grass fiber and $40-50 \%$ of legume fiber), but legume fiber digests at a 
faster rate (Buxton and Brasche, 1991). The generally greater rate of cell wall degradation for legume than grass is thought to be a function of more restricted or localized deposition of lignin and greater proportion of core (localized) lignin than non-core (free) lignin (Jung, 1989). Further, a lower proportion of noncore (free) lignin in legume than in grass might be associated with less inhibitory effects of free phenolic (lignin) monomers on microbial activity (Fukushima et al., 1991). Consequently, increased lignification of legume leaves with maturation depresses $\mathrm{CHO}$ digestibility less than lignification of grass leaves, in part because there is less free lignin in legume to bind with non-cellulosic polysaccharides. These factors presumably contribute to a smaller change in legume digestibility with increasing maturity compared to grass (Sharma et al., 1988; Galyean and Goetsh, 1993).

Moseley and Dellow (1985) reported that ruminants spent 40\% more time eating and $90 \%$ more time ruminating grass than legume because of greater particle breakdown by mastication of legume than grass. Lower cell wall content and cubical nature of legume particles compared to long and slender grass particles (Minson, 1990), less lignin-CHO bonding, and the localization of lignification to certain cell compartments in legume compared to grass, enhances legume susceptibility to microbial attack compared to grass (Akin, 1989). 


\section{Diurnal variation in nutrient content}

Seasonal and diurnal variations in nutrient content (mainly carbohydrate and $\mathrm{N}$ ) in forage crops are important considerations for making grazing management decisions (Wilkinson et al., 1994). Holt and Hilst (1969) reported that water soluble carbohydrate (glucose, fructose, sucrose) content in Kentucky bluegrass (Poa pratensis L.), bromegrass (Bromus inermis L.) and tall fescue (Festuca arundinacea L.) increased linearly from $0600 \mathrm{~h}$ to $1800 \mathrm{~h}$. The water soluble carbohydrate content in alfalfa followed a curvilinear diurnal trend from low at $0600 \mathrm{~h}$ to maximum levels at $1200 \mathrm{~h}$ and decreased slightly by $1800 \mathrm{~h}$. Nonstructural polysaccharide (mainly starch) content followed a nonlinear daily trend peaking in the afternoon.

The concentration of various carbohydrates and $\mathrm{N}$ in plants varies diurnally, presumably in response to changes in light intensity, temperature, and other environmental factors (Youngberg et al., 1972). Light has a direct role in carbohydrate synthesis, temperature in carbohydrate assimilation, and moisture in carbohydrate translocation (Lechtenberg et al., 1971). Lechtenberg et al. (1971) further reported that leaf starch of alfalfa increased from 10.2 to $20.3 \%$ of the DM during daylight hours, most of the increase occurring between $0900 \mathrm{~h}$ and $1500 \mathrm{~h}$. In vitro DM digestibility averaged $1.6 \%$ higher at $1800 \mathrm{~h}$ than at $0600 \mathrm{~h}$. Thus, farmers may take advantage of the diurnal variation in forage quantity, constituency and digestibility by harvesting or grazing late in the 
afternoon or evening when DM and water soluble carbohydrates are highest (Mayland et al., 1998; Orr et al., 1997).

D. Forage type

Cool season grasses are more digestible than warm season grasses because the proportion and arrangement of tissues differ as a result of differences in photosynthetic pathways and optimal growing temperatures (Akin, 1989). The $\mathrm{C}_{3}$ plants (cool season grasses and legumes) fix $\mathrm{CO}_{2}$ by the reductive pentose phosphate pathway whereas $\mathrm{C}_{4}$ plants (warm season grasses) fix $\mathrm{CO}_{2}$ by the $\mathrm{C}_{4}$ dicarboxylic acid pathway (Voet and Voet, 1995).

The main advantage of $C_{3}$ over $C_{4}$ grasses is that $C_{3}$ plants have greater proportion of highly degradable mesophyll tissue and that this tissue appears to be more loosely arranged than that in $\mathrm{C}_{4}$ plants, allowing easier microbial attack (Hanna et al., 1973). Also, the proportion of parenchyma bundle sheath is greater in $C_{4}$ than $C_{3}$ species, and this tissue is generally slowly or only partially degraded and contributes to more rigid residue (Akin, 1982, 1986). In contrast, the parenchyma bundle sheath of $C_{3}$ grasses is rapidly and extensively degraded, probably because phenolic compounds (lignin) do not limit degradation as in $\mathrm{C}_{4}$ grasses (Akin, 1982). Thus, warm season grasses have a greater proportion of the less digestible stem and reach flowering more quickly than cool season grasses (Galyean and Goetsch, 1993). In addition, lag time of ruminal cell wall digestion is longer and digestion rate slower for warm season grasses than for cool season grasses and legumes, perhaps because adherence time of bacteria 
to particles is longer and concentration of phenolic acids (lignin) is greater for warm season grasses than for cool season grasses (Mertens and Loften, 1980; Akin, 1986).

Minson and McLeod (1970) reported that temperate grasses were $12.8 \%$ more digestible than tropical grasses cut at any stage of growth mainly due to the influence of ambient temperature (accounts for about $60 \%$ of the difference) and anatomical structure differences (accounts for the remainder). High temperature reduces DM digestibility by increasing the amount of cell wall and its lignification as well as promoting stem development. Differences between tropical and temperate legumes were small since both plants are $C_{3}$ species and their leaves have similar anatomical structure (Minson and McLeod, 1970).

\section{E. Physiological maturity}

Marked physiological changes take place as forage matures. The ratio of cell walls to cell contents and degree of lignification of cell walls increase (Hodgson, 1990), and stem to leaf ratio rapidly increases (Ulyatt, 1981; Wilman et al., 1976). Leaves lose cell contents steadily with advancing senescence, thus, digestibility of dead leaf tissue declines to $40-50 \%$ (Hodgson, 1990). The $\mathrm{N}$ content of the DM of young herbage, typically in the range of 3-4\%, declines to as low as $1 \%$ in very mature forage. In addition, structural carbohydrates (digested slowly) and lignin (indigestible) increase rapidly in stems and slowly in the leaves, contributing to the decline in digestibility in mature forage (Ulyatt, 1981). 
A rapid turnover of tissue takes place as new leaves are continually produced and old ones die (Hunt, 1965). In perennial ryegrass a new leaf appears on each tiller on average every 11 days (April to September), but as only three live leaves per tiller are maintained, average longevity of leaves is just 33 days (Davies, 1977). Thus, optimum utilization of ryegrass may require more frequent defoliation to minimize the effects of old or dead material. As forage matures digestibility declines because $\mathrm{N}$ decreases, and fiber and lignin contents increase; these changes may be accompanied by decreased forage intake, ruminal $\mathrm{NH}_{3}$ concentrations, total volatile fatty acid (VFA) concentrations and increased acetate to propionate ratio (Van Soest, 1994).

Funk et al. (1987) reported that in vitro OM digestibility and dietary $\mathrm{N}$ decreased and fiber content increased $(P<0.05)$ as forage (mainly blue grama rangeland) matured through the growing season. Park et al. (1994) reported that total masticate $\mathrm{N}$, in vitro OM disappearance and OM intake of intermediate wheatgrass decreased while bound $\mathrm{N}$ increased $(P<0.05)$ with each sampling date (April through December). Cherney et al. (1993) reported that NDF increased from 40.0 to $62.7 \%$, indigestible fiber increased from 6.0 to $25.5 \%$, lignin increased from 1.7 to $5.3 \%$ whereas digestibility of fiber decreased from 79.9 to $44.2 \%$ as maturity of cool season perennial grasses increased from May to mid June. The authors also found a strong negative correlation $(r=-.78)$ between lignin and fiber digestibility as forage matured, generally agreeing with other literature (Akin, 1989; Van Soest, 1994). 
The decline in nutritive value of forages is considered to be linear with physiological maturity (Blaser et al., 1986) and has implications on forage utilization (Burns, 1981). Burns et al. (1997) reported that OM and NDF digestibility of switchgrass (Panicum virgatum L.) decreased $(P<0.05)$ while NDF, $A D F$, acid detergent insoluble $C P$, and undegradable intake $C P$ increased linearly $(P<0.01)$ with advancing season when fed to steers. Steer responses were indicative of increasingly mature forage. Cherney et al. (1993) and Johnson et al. (1998) reported similar results.

Elizalde et al. (1999) reported that the extent of ruminal DM and CP degradation by steers decreased with maturity of alfalfa and tall fescue, due to increased proportion of rumen undegradable CP as a percentage of CP. Further, a decrease in intake as forage matured could be attributed to chemical (mainly nutrient content) and physical (leaf to stem ratio and particle size) changes (Weston and Poppi, 1987). Seasonal changes in forage intake and ruminal fermentation of cool season forages suggest that animal performance might be increased if supplemental energy is provided early in the growing season; however, supplemental protein would likely be needed as these forages mature (Cherney et al., 1993).

F. Forage height and density

Forage height or sward height $(\mathrm{SH})$ is an important variable that can be used to estimate forage mass ( $\mathrm{kg} / \mathrm{ha})$ and, when measured on a regular basis, forage growth rate $(\mathrm{kg} / \mathrm{unit}$ time). Sward height can be estimated using the Hill 
Farming Research Organization (HFRO) sward stick, rising plate meter or a graduated measuring stick. Bransby et al. (1977) reported a positive correlation between forage height and DM yield; as sward height increased, forage mass also increased. Wright et al. (1990) reported that cows on high $(7-8 \mathrm{~cm})$ sward surface height (SSH) consumed more forage (10.8 vs $8.9 \mathrm{~kg} \mathrm{OM} / \mathrm{d}$ ) compared to those on low $(4-5 \mathrm{~cm}) \mathrm{SSH}$. Similarly, calves on high SSH gained more (1.40 vs $0.63 \mathrm{~kg} / \mathrm{d}$ ) compared to those on low SSH.

Forage height has an inverse relationship with quality (Minson, 1990). Consequently, forage DM intake is affected by grazing behavior (small bite size and insufficient grazing time) of animals in response to low forage height. In such circumstances, quantity of forage and not quality, should be limiting animal productivity. Reports by Mayne et al. (1987) concluded that a reasonable compromise between sward utilization (mainly perennial ryegrass) and animal performance can be achieved by grazing cows to a residual sward height of $6 \mathrm{~cm}$ (SSH of $8 \mathrm{~cm}$ ) as assessed by the rising-plate sward stick. Cool season pastures maintained at $8-10 \mathrm{~cm}$ provide the best compromise between forage quality and intake of grazing beef (Prigge et al., 1997) and dairy (Rook et al., 1994a) cattle.

In temperate grass swards, $\mathrm{SH}$ is the dominant variable influencing shortterm forage intake in grazing animals (Hodgson, 1981; Jamieson and Hodgson, 1979a, b). The dominant influence on intake of warm-season grasses is leaf density and leaf to stem ratio (Forbes, 1988). In swards with short or no flower horizons, such as Bermuda grass, bite size increases steadily with increasing 
sward height. However, in swards with tall flower canopy, such as brome grass, bite size declines markedly with the appearance of flower horizons (Forbes, 1988). Reduction in bite size after appearance of flower heads presumably occurs because animals become more selective and because the leaf density of the surface horizon is reduced greatly. In situations where forage intake is increasingly limited by bite size, the need for supplementation with concentrates becomes more appropriate.

G. Forage allowance

Forage allowance refers to forage mass (kg DM) available to an animal per day. It is usually expressed as $\mathrm{kg} \mathrm{DM} \cdot a n i m a l^{-1} \cdot \mathrm{d}^{-1}$ or $\mathrm{g} \mathrm{DM} \cdot \mathrm{kg} \mathrm{BW}^{-1} \cdot \mathrm{d}^{-1}$, the latter accounts for differences in animal BW. Forage allowance is a component of grazing ecosystems that lends itself most readily to manipulation by grazing management (Hodgson, 1984). The relation between intake and forage allowance is generally curvilinear, once the allowance of desired forage is less than twice the maximum intake, there is progressive fall in quantity of forage consumed (Combellas and Hodgson, 1979). Hodgson (1975) suggested that herbage intake and milk production of the grazing dairy cow are maximized when the daily herbage allowance is equivalent to four times the amount consumed. Mayne et al. (1987) reported that in a rotationally grazed perennial ryegrass-clover pasture, average milk yields of dairy cows maintained at low, medium and high herbage allowance (36, 53 and $63 \mathrm{~g} \mathrm{OM} / \mathrm{kg} \mathrm{BW}$, respectively) was $11.8,14,6$ and $14.5 \mathrm{~kg} / \mathrm{d}$, respectively, generally agreeing with Hodgson 
(1975). Redmon et al. (1995) reported that forage intake, OM disappearance (OMD), and estimated daily gain of steers grazing winter wheat pasture ( Triticum aestivum var. Chisholm) were related to forage allowance. As herbage allowance increased, intake, OM digestibility and estimated daily gain improved; forage intake and estimated ADG declined severely when herbage allowance fell below $0.24 \mathrm{~kg} \mathrm{DM} \cdot \mathrm{kg} \mathrm{BW}^{-1} \cdot \mathrm{day}^{-1}$.

Under ideal conditions, herbage removal by grazing should match herbage growth and herbage allowance will be considered constant (Hodgson, 1990). However, in many grazing situations, rate of sward depletion by grazing exceeds the rate of sward growth and the animal is offered gradually diminishing herbage allowance as the grazing season advances. Response to concentrate input seems to be higher when herbage allowance is low (Wilkins et al., 1995; Jennings and Holmes, 1984), or when the stocking rate is very high (Hoden et al., 1991). Reports by Meijs and Hoekstra (1984) concluded that at a low daily herbage allowance (16 kg OM/cow), approximately $4 \mathrm{~cm}$ cutting height, mean substitution rate of herbage by concentrate was 0.1 ; at a high daily herbage allowance (24 $\mathrm{kg} \mathrm{OM} / \mathrm{cow})$, substitution rate increased to 0.5 . Substitution rate refers to the amount of forage DM that is replaced for each $\mathrm{kg}$ DM of concentrate consumed. In general, substitution rate varies between 0.5 and 0.9 $\mathrm{kg}$ forage DMI for each kg of grain fed (Kellaway and Porta, 1993), depending on gut fill, supply of energy, $\mathrm{CP}$, ruminally degradable protein, stage of lactation, and pasture availability. 
Reduction in herbage intake resulting from supplementation is manifested mainly through a reduction in grazing time. Meijs and Hoekstra (1984) reported a reduction of in grazing time of 3-20 minutes/ $\mathrm{kg}$ DM concentrate fed with little effect on rate of biting or bite size. To obtain an increase in milk yield similar to that obtained with $1 \mathrm{~kg} \mathrm{DM} / \mathrm{d}$ of concentrate, it is necessary to increase the herbage allowance by $5 \mathrm{~kg} \mathrm{DM} / \mathrm{d}$ (Hoden et al., 1991).

\section{Supplementation}

The objective of feeding supplements to cattle is to increase or maintain their productive performance (growth, reproduction and lactation). Concentrate supplements, mainly energy and $\mathrm{CP}$, are fed to grazing animals to supply deficient energy and protein (NRC, 1989). Energy supply to the rumen may be most effective when there is a rapid $\mathrm{NH}_{3}$ production and loss of protein. The supplemental energy will allow for the capture of $\mathrm{NH}_{3}-\mathrm{N}$ by the rumen microbes in the form of microbial protein. Rapid ruminal $\mathrm{NH}_{3}-\mathrm{N}$ production occurs with temperate pastures especially in spring, some of the tropical legumes, and most probably with tropical grasses immediately following rain (Poppi and McLennan, 1995). To be effective, there must be synchrony between energy and $\mathrm{NH}_{3}$ release in the rumen (Galyean and Owens, 1991). However, grain supplements may decrease forage intake and utilization (Horn and McCollum, 1987), the effect depending on level and type of grain fed. Animal response to supplements may depend on type, amount and time of feeding. 


\section{A. Energy supplements}

High-energy feeds can be grouped into two main subclasses, cereal grains and by-product feeds. Cereal grains (e.g. corn, wheat, barley, and oats) contain high amounts of starch and are low in fiber whereas most by-product feeds (e.g. wheat midds, seed hulls, sugar beet pulp) are also high in fiber.

Cereal grains

Depending on quality of forage on offer, energy supplements generally increase animal performance. Elizalde et al. (1998) reported that supplemented steers grazing endophyte-infected tall fescue had higher ADG than unsupplemented steers ( 0.74 vs. $0.64 \mathrm{~kg} / \mathrm{d})$; however, total OM intake and OM digestibility did not differ $(P>0.10)$ among treatments, suggesting that supplemented animals utilized metabolizable energy more efficiently than the unsupplemented group. In this study, steers were fed either ground or whole corn with hay or $4 \mathrm{~h}$ after hay was fed. The authors concluded that starch utilization was highest for the ground corn as opposed to the whole corn treatment, regardless of time that the concentrate was fed.

Grain processing could influence animal performance. Wu et al. (2001) reported higher milk yield and milk protein, and lower milk fat for cows fed supplemental ground high moisture shelled corn (HMC) compared to dry cracked shelled corn (22.9 vs $20.5 \mathrm{~kg} / \mathrm{d}, 3.26$ vs $3.15 \%$, and 3.28 vs $3.67 \%$, respectively). The cows (in late lactation) were grazing high quality $(17.7 \% \mathrm{CP})$ pasture. The greater effect of ground HMC over cracked dry corn was likely due 
to greater ruminal fermentation and digestion of starch in the $\mathrm{HMC}$, increasing the supply of protein and ME. Reports by Reis and Combs (2000) indicated that total DMI, DM digestibility and milk yield increased as grain supplementation increased. Ruminal $\mathrm{pH}$ and total VFA concentration were not affected by supplementation, but ruminal $\mathrm{NH}_{3}$ concentration was reduced, probably because of a decrease in $\mathrm{N}$ intake and greater use of $\mathrm{NH}_{3}-\mathrm{N}$ for ruminal microbial synthesis. In contrast, Soriano et al. (2000) showed no differences in milk yield (30.3 kg/d), milk protein $(2.97 \%)$, and milk urea N (14.7 mg/dl) of Holstein cows (107 days in milk) grazing high quality pasture (>19\% CP) fed supplemental HMC, coarsely ground or finely ground corn.

Cereal grains differ in their rates and extent of fermentation. Barley and wheat are fermented more rapidly by ruminal microbes than corn and sorghum (Nordin and Campling, 1976; Cone et al., 1989). Compared to corn, barley starch is generally more rapidly fermented in the rumen and has greater concentration of rumen degradable protein (Herrera-Saldana et al., 1990b). Feeding a highly fermentable grain such as barley may have a greater detrimental effect on ruminal fiber digestion than a less fermentable grain (Ørskov and Fraser, 1975). For most grains, $90 \%$ or more of starch is normally fermented in the rumen, however, for others such as corn and milo, up to $30 \%$ or more could escape ruminal fermentation (Ørskov, 1986).

Herrera-Saldana et al. (1990b) reported that assuming a passage rate of $6 \% / h$, the calculated ruminal availability of starch from oats, wheat, barley, corn, 
and milo was 98, 95, 90, 62, and 49\%, respectively. The low ruminal availability of milo is probably due to the protein matrix associated with starch granules, type and proportion of protein found in the endosperm and proportion of the endosperm. However, when rapidly degradable carbohydrates such as oats, wheat, and barley are fed in large quantities, fiber digestion may be disrupted limiting their inclusion in diets for grazing ruminants. Effect of various grain sources on intake and digestive processes in ruminants depends on forage type, level and type of supplement. Brake et al. (1989) reported that total DMI and OM digestibility of Holstein steers supplemented with barley or corn was higher for orchardgrass than bermudagrass and higher for barley than corn.

Casper et al. (1999) reported greater milk production for cows fed cornbased diets compared to cows fed barley-based diets (26.3 vs $23.7 \mathrm{~kg} / \mathrm{d}$ ) although DMI was similar for both groups. The slightly greater starch content of corn diets that is less rapidly degraded and greater proportion escaping ruminal fermentation may have contributed to greater milk production for cows fed corn compared to barley. Ruminal $\mathrm{NH}_{3}-\mathrm{N}$ and rumen VFA concentrations were greater for cows fed corn than those fed barley (15.0 vs $9.0 \mathrm{mg} / \mathrm{dl}$ and $133 \mathrm{vs}$ $121 \mu \mathrm{mol} / \mathrm{ml}$, respectively). However, fractional passage rates of solids from the rumen were greater for cows fed barley than those fed corn (4.2 vs 3.4\%/h). Results of this study are consistent with earlier work (Casper and Schingoethe, 1989; Casper et al., 1990) which concluded that non structural carbohydrate 
solubility, but not degradability, influences milk production when lactating cows are fed diets based on corn or barley.

Contrary to previous studies, Feng et al. (1995) reported that various corn/barley mixtures provided at $30 \%$ or $35.5 \%$ of diet DM had no effect $(P>$ 0.10) on DMI, ruminal particulate passage rate, and total tract NDF digestibility of ruminally cannulated steers fed low quality grass hay-based diets $(8.2 \% \mathrm{CP})$. Ruminal and total tract DM, and starch digestibility were greater $(P<0.01$ and $P$ $<0.10$, respectively) for barley than corn containing diets. The authors concluded that ruminal and total tract digestibility, and protein flow to the small intestines could be increased more with barley than corn as energy supplement to grass hay-based diets. Vanzant et al. (1990) did not find differences in forage intake and utilization between supplemented rolled sorghum grain (upto $0.66 \%$ of BW, as fed) and unsupplemented yearling steers grazing big bluestem pastures $(6.1 \% \mathrm{CP})$ in the spring and early summer. In this study, amount of supplements fed was less than amount suggested by Horn and McCollum (1987) $(0.7 \%$ of $\mathrm{BW})$ to affect forage fermentation and consequent forage intake and may explain the lack of supplement effect.

Berzaghi et al. (1996) did not find differences in total OM intake between diets of pasture only or pasture plus $6.4 \mathrm{~kg} / \mathrm{d}$ cracked corn and mineral mix, however, forage OM intake was lower for cows fed corn supplement. Apparent ruminal and total tract digestibility of OM and NDF were lower for supplemented than for unsupplemented cows. Milk yield increased for supplemented cows 
over the unsupplemented group ( 23.7 vs $19.5 \mathrm{~kg} / \mathrm{d}$ ), probably because supplemental corn increased energy intake, reduced ruminal $\mathrm{NH}_{3}-\mathrm{N}$ concentration and increased recovery of intake $\mathrm{N}$ at the duodenum.

In a review, Moore et al. (1999) found little relationship between changes in voluntary forage intake and sources of supplemental energy and CP. The authors concluded that the lowest increases in ADG were with native forages supplemented with molasses alone or low molasses containing high levels of NPN; whereas the greatest increases in gain were with improved forages, supplements with greater than $60 \%$ TDN, and supplemented CP intake greater than $0.05 \%$ of BW. Supplements decreased voluntary forage intake when supplemental TDN intake was greater than $0.7 \%$ of $\mathrm{BW}$, or forage TDN to CP ratio was less than 7 (adequate $\mathrm{N}$ ), or when fed alone, forage intake was more than $1.75 \%$ of BW (high quality forage).

Feeding supplemental diets high in energy or protein before and after calving could influence cow weight and condition, reproductive performance, and calf weight gain. Marston et al. $(1995 a, b)$ reported that cows fed energy-based diet $(2.44 \mathrm{~kg} / \mathrm{d}, 20 \% \mathrm{CP})$ before and after gestation had greater bodyweight gain at calving $(P<0.01)$ and greater pregnancy rate $(P<0.01)$ than cows fed a protein-based diet $(1.22 \mathrm{~kg} / \mathrm{d}, 40 \% \mathrm{CP})$. Cow performance postpartum and calf-weaning weight, were not affected by supplementation $(P>0.10)$. The authors concluded that conception rates were significantly improved by feeding higher levels of supplemental energy prepartum but not postpartum. 
Supplemental energy fed to yearling cattle on pasture usually results in increased rates of gain. However, rate of gain and efficiency during subsequent finishing in the feedlot (for steers previously supplemented) have been reported (Denham, 1977) to decrease because of compensatory gains by nonsupplemented animals. Perry et al. (1971) reported daily gains greater than 0.3 $\mathrm{kg} / \mathrm{d}$ for supplemented yearling cattle on pasture; however, feedlot gains during the finishing phase were negatively correlated with pasture gains. Similarly, Coleman et al. (1976) reported that yearling cattle on pasture fed an energy supplement gained more $(0.67$ vs $0.38 \mathrm{~kg} / \mathrm{d})$ than the unsupplemented group. Feedlot gains ( $0.99 \mathrm{~kg} / \mathrm{d}$ for all groups), carcass quality grade and estimated $\%$ yield were not affected; however, dressing percentage and back fat thickness of supplemented cattle was greater than for the unsupplemented group.

By-product feeds

To prevent adverse effects of starch on ruminal fiber digestion (Gekara et al., 2001), high-fiber by product feeds (e.g. wheat midds, soybean hulls, and corn gluten feed) and lipids (mainly vegetable oils e.g. soybean oil, canola oil) offer alternatives to grain for formulating high-energy supplements. Anderson et al. (1988) reported that soy hulls and corn elicited a similar animal response; they both increased $(P<0.05)$ ADG of growing beef calves by $0.17 \mathrm{~kg} / \mathrm{d}$ over the unsupplemented group. Soy hulls have an advantage over corn in that they contain high amounts of digestible fiber (NDF and ADF) rather than starch and, 
therefore, supply supplemental energy while minimizing changes in ruminal fermentation.

Horn et al. (1995) reported that steer calves raised for feedlot finishing and fed supplemental corn-based high-starch or soybean hull/wheat middsbased high-fiber diets $(0.65 \%$ of BW) had similar ADG $(1.07 \mathrm{~kg} / \mathrm{d})$. However, supplemented steers gained more $(1.07 \mathrm{vs} 0.92 \mathrm{~kg} / \mathrm{d})$ than the unsupplemented group. The authors suggested that ADG and increased stocking density should be considered, along with costs, in selecting an energy supplement for growing cattle grazing a wheat pasture. Forster et al. (1993) suggested that rice bran supplemented at $0.38 \%$ of BW either separately or mixed with corn at $0.25 \%$ of BW, may be as great in value as corn given separately in respect to gain of Holstein steer calves grazing forage of moderate to high quality (greater than $12 \% \mathrm{CP})$.

Lipid sources can be added to grain supplements to increase energy density of the supplement without increasing the level of grain feeding. Brokow et al. (2001) reported that soybean oil ( $12.5 \%$ of supplemental DM, replaced corn on a TDN basis) inclusion in the diet had no adverse effects on animal performance; however, flow of microbial $\mathrm{N}$ was more depressed for soybean oil than for the corn treatment. The authors suggested that feeding low levels of supplemental grain with soybean oil $(0.30 \%$ of $B W)$ or without $(0.35 \%$ of $B W)$, is an effective strategy of increasing dietary energy for cattle grazing high quality forages $(19 \% \mathrm{CP})$. 


\section{B. High CP supplements}

A goal in the protein formulation of diets is to provide adequate amounts of amino acids to the animal for optimal efficiency and desired animal productivity with minimum amounts of dietary CP (NRC, 2001). Dietary CP can be classified as either ruminally degradable or ruminally by-pass fraction. The terms ruminally degradable $\mathrm{CP}$ (RDP) and degradable intake $\mathrm{CP}$ (DIP) refer to that portion of protein that is degraded by rumen microorganisms in the rumen. Ruminally undegradable CP (RUP) and undegradable intake CP (UIP) refer to that portion of $\mathrm{CP}$ that by-pass ruminal degradation. Efficient use of dietary $\mathrm{CP}$ requires selection of feed and supplement $\mathrm{N}$ that will provide adequate RDP for maximal synthesis of microbial CP and RUP that will optimize the profile and amounts of absorbed amino acids (NRC, 2001). Presumably, RDP could be complemented by supplementation (NRC, 2001) with readily available forms of energy or RUP.

For growing cattle, protein nutrition is critical because a deficiency of $1 \mathrm{~g}$ of protein per day can reduce gain by $10 \mathrm{~g} / \mathrm{d}$ (NRC, 1984). Moreover, animal responses to supplemental protein usually are observed when the CP content of forages is less than 6 to $8 \%$ (Campling, 1970). Supplemental proteins high in RDP include soybean meal (SBM), linseed meal, sunflower meal; high RUP proteins include heated/chemically treated SBM, distillers' grains, brewers' grains, blood meal, corn gluten meal (CGM), meat and bone meal, or blends of these sources (NRC, 2001; Santos et al., 1998a). Immature forages often contain an 
excess of RDP. However, as forages mature $\mathrm{CP}$, particularly RDP may become limiting; consequently, supplements containing appreciable quantities of RDP can stimulate microbial fermentation and forage utilization (Drouillard and Kuhl, 1999).

Ruminally degradable CP

Protein supply to the intestinal tract for absorption in ruminants is influenced by ruminal degradability of dietary $\mathrm{CP}$ and production of microbial protein. Supplemental RDP fed to beef cattle consuming low quality forages (6.1\% CP) increased forage DMI and digestibility (McCollum and Galyean, 1985) and improved cow BW and condition (DelCurto et al., 1990). In grazing systems utilizing low-quality winter forages, RDP is often deficient and does not meet the metabolizable protein requirements of cows. Jordon et al. (2002) suggested that feeding dried poultry waste as a cheap source of supplemental RDP could provide a more favorable rumen $\mathrm{NH}_{3}$ production, increasing efficient $\mathrm{N}$ utilization, and, may replace SBM for cows grazing low-quality winter forages.

Garrett et al. (1987) reported that the flow of bacterial non-ammonia N to the duodenum was highest when steers were fed SBM or linseed meal, intermediate for urea and lowest $(P<0.05)$ for $\operatorname{CGM}(86.8,86.1,76.3$, and 65.9 $\mathrm{g} / \mathrm{d}$, respectively). Ruminal digestion of dietary CP was greater in steers fed urea than those fed CGM, but intermediate for steers fed SBM and linseed meal (58.4, 48.8, 53.1, and 53.9\%, respectively). Thus, when CP sources high in 
RUP are fed, inclusion of sources high in RDP should be considered to maximize microbial efficiency of energy and $\mathrm{N}$ utilization.

Reports by Bodine et al. (2000) indicated that intake of hay (6\% CP) and total OM increased quadratically $(P<0.01)$ in response to added DIP with or without supplemental corn. The authors concluded that providing adequate supplemental RDP seemed to overcome negative associative effects typically seen when supplementing low-quality forages with large quantities of lowprotein, high-starch feeds. In a related study, Bodine et al. (2001) reported that feeding high-grain vs high-fiber pelleted energy supplements formulated to provide adequate RDP did not alter forage intake or OM digestibility. In this study, an adequate RDP to TDN balance decreased the negative associative effects often observed when large quantities of high-starch supplements are fed with low-quality hay. McCollum and Galyean (1985) reported that intake of low quality prairie hay $(6.1 \% \mathrm{CP})$ increased $(P<0.01)$ and digesta passage rate was faster $(P<0.01 ; 4.5$ vs $2.9 \% / h)$ when beef steers were supplemented with CSM at the rate of $800 \mathrm{~g} / \mathrm{d}$. It is not clear from this study whether the increased passage rate is a function of increased intake because of metabolic responses to protein supplementation, or to increased rate of fermentation of DM in the rumen.

In some studies, CP supplements have either elicited minimal or no response at all. McCormick et al. (2001) reported that type of CP supplement (SBM or CGM), had no effect $(P>0.10)$ on forage DMI $(12.7 \pm 1.0 \mathrm{~kg} / \mathrm{d})$, total 
DMI $(23.9 \pm 1.2 \mathrm{~kg} / \mathrm{d})$ or milk yield $(30.3 \mathrm{vs} 28.9 \mathrm{~kg} / \mathrm{d})$ of grazing dairy cows. In grazing systems utilizing high quality forage (25.6\% CP), CP is rapidly degraded in the rumen (Hongerholt and Muller, 1998) and $\mathrm{NH}_{3}-\mathrm{N}$ surplus and extensive ruminal N losses may occur (Beever and Siddons, 1986). The lack of response to supplemental RDP when dairy cows are grazing pastures containing more than $15 \%$ CP may be due to high $\mathrm{N}$ losses in the rumen (Hamilton et al., 1992). In such cases, supplemental CP high in RUP can elicit the desired animal response. In addition, diets high in RDP (in excess of NRC recommendations) have been shown to be detrimental to cow reproductive performance (Canfield et al., 1990; Blanchard et al., 1990).

Ruminally undegradable CP

Studies from the 1960s (Virtanen, 1966) showed that the rumen is capable of supplying the required protein of cows producing up to $4500 \mathrm{~kg} / \mathrm{cow}$ per lactation. However, milk yield per cow in the US has more than doubled during the last 30 years, approaching $14000 \mathrm{~kg}$ per lactation. Thus, microbial protein synthesis increasingly cannot meet the high protein requirements, and significant amounts of dietary protein must escape ruminal degradation (Santos et al., 1998) to supply these needs.

In a review, Santos et al. (1998b) concluded that increasing RUP per se in dairy cow diets, which often results in decreased RDP and change in absorbed amino acid (AA) profiles, does not consistently improve lactation performance. Possible reasons for lack of response include decreased microbial synthesis in the 
rumen, RUP source with a poor essential AA profile, RUP source with low digestibility in the small intestine (Schingoethe, 1991), and control diets already sufficiently high in RUP (NRC, 2001).

Feeding proteins that are resistant to microbial degradation in the rumen has been proposed to increase the amount of dietary protein reaching the small intestine (Stern et al., 1983). For a RUP source to elicit a positive response, the AA profile (mainly Lys and Met, first and second limiting AA, respectively) should complement that of microbial protein (Schingoethe, 1991; Clark et al., 1992). Schwab (1994) suggested that the amount of Lys and Met in duodenal digesta for maximizing milk and milk protein yields should be 15 and $5 \%$ of total essential AA, respectively. Hence, RUP sources low in Lys and Met might result in no increase or a decrease in milk yield and composition.

Shroeder and Gagliostro (2000) reported that milk and milk protein yields were increased by fishmeal compared to sunflower meal ( 26.8 vs 25.6 , and 0.90 vs $0.81 \mathrm{~kg} / \mathrm{d}$, respectively). The authors attributed the higher milk yield observed to the quality of absorbed protein and higher glucose availability to the mammary gland because fishmeal has a higher concentration of RUP. Schor and Gagliostro (2001) reported that early-lactation dairy cows grazing moderate quality pastures $(13.7 \% \mathrm{CP})$ supplemented with fishmeal consumed more forage DM (17.2 vs $13.2 \mathrm{~kg} / \mathrm{d})$, produced more milk (29.3 vs $24.9 \mathrm{~kg} / \mathrm{d}$ ) and reduced ruminal $\mathrm{NH}_{3}-\mathrm{N}$ levels compared to the SBM-supplemented group. The authors 
attributed the higher milk yield to increased DMI rather than enhanced body lipid mobilization.

In contrast, replacing a RDP source for RUP source resulted in no effect on DMI and $\mathrm{N}$ intake in several studies (Armentano et al., 1986; Chan et al., 1997; Mabjeesh et al., 1996). Microbial $\mathrm{N}$ flow to the small intestine was decreased $(P<.05)$ by high RUP sources ( 275 vs $240 \mathrm{~g} / \mathrm{d})$, suggesting that when high RUP sources replaced SBM, a RDP shortage probably limited microbial synthesis. Reports of Bargo et al. (2001) indicated that level and source of supplemental protein (low/high sunflower meal or high protein feather meal) did not affect forage DMI $(13.2 \mathrm{~kg} / \mathrm{d})$, total DMI $(19.6 \mathrm{~kg} / \mathrm{d})$ and milk yield $(20.5$ $\mathrm{kg} / \mathrm{d}$ ) of cows grazing oats (Avena sativa L.) in the winter. The authors concluded that higher RUP intake (feather meal) did not increase animal performance, suggesting that RUP was not limiting for cows on pasture producing less than $22 \mathrm{~kg}$ of milk/d. Hongerholt and Muller (1998) reported that supplemental grain mixture (high in RUP) content did not alter DMI or milk yield of high yielding cows rotationally grazing high quality pasture $(25 \% \mathrm{CP})$, however, milk protein tended to be higher for cows on RUP supplement. McCormick et al. (2001) made similar observations for Holstein cows grazing immature winter annual pastures $(25 \% \mathrm{CP})$, indicating that energy, and not protein, may have been the major nutritional constraint limiting milk yield.

Supplements high in RUP have been shown to improve reproduction when fed in excess of NRC recommendations (Wiley et al., 1991). However, feeding 
excess CP has also been reported to increase days to first ovulation (Carroll et al., 1988) or lower fertility (Jordan and Swanson, 1979). Although the exact mechanism on how excess $\mathrm{CP}$ affects reproduction is not known, high protein diets probably elevate plasma urea N (Carroll et al., 1988) and urea is thought to decrease bovine sperm viability (Duby and Trischler, II, 1986).

Crude protein content

Animal responses (intake and digestibility) to supplements may depend on the CP level of the supplement and forage offered. Marston and Lusby (1995) reported that gestating and lactating beef cows fed SBM-based protein diet (40\% $\mathrm{CP}$ ) consumed $1 \mathrm{~kg} \mathrm{DM} / \mathrm{d}$ more prairie hay $(<5 \% \mathrm{CP})$ and hay digestibility was greater $(P<0.001)$ than for cows fed soybean hull-based energy diet $(20 \% \mathrm{CP})$. However, total metabolizable energy intake was similar $(P=0.35)$ for both treatments. The authors concluded that increasing total energy intake of cows consuming low-quality forage by feeding energy supplements is difficult after meeting protein requirements. Reports of DelCurto et al. (1990) concluded that beef cow body condition and bodyweight losses during winter grazing period were minimized with increasing supplemental CP concentration (13, 25 and 39\% $\mathrm{CP})$. However, intake and utilization of dormant forage $(8.7 \% \mathrm{CP})$, mainly bluestem (Andropogon gerardii L.), by steers were improved with moderate ( $25 \%$ CP) levels of supplemental protein.

In contrast, Karges et al. (1992) reported that steers grazing summer native range grass species $(<14 \% \mathrm{CP})$ and fed supplemental RDP or RUP 
showed no response to RDP supplement; however, a linear gain response $(P<$ 0.01) was observed in steers fed RUP. Results of this study suggested that microbial protein synthesis may be insufficient to satisfy the metabolizable protein requirement, probably limiting steer gains. Wheeler et al. (2001) reported that supplemental protein concentration did not alter forage DMI, total OMI, apparent digestibility of OM or NDF, cumulative cow weight change or cumulative body condition score. However, protein supplemented cows (at 0.2 , 0.4 and $0.6 \mathrm{~g}$ of supplemental protein/ $\mathrm{kg}$ of BW) lost less weight and condition compared to unsupplemented animals.

C. Time of supplementation

For supplements to be effectively utilized on pasture there should be synchronous availability of carbohydrate $(\mathrm{CHO})$ and $\mathrm{NH}_{3}$ release in the rumen to maximize microbial protein synthesis and minimize the negative effects of carbohydrate fermentation on fiber digestion. Thus, the time of day when supplemental energy or protein is fed is critical and could influence the synchronous availability of $\mathrm{CHO}$ and $\mathrm{NH}_{3}$. Providing a more stable ruminal $\mathrm{NH}_{3}^{-}$ $\mathrm{N}$ concentration through synchronous availability of $\mathrm{NH}_{3}$ and $\mathrm{CHO}$ usually increases fiber utilization (Hoover, 1986; Mould and Ørskov, 1984).

Grazing behavior (Adams, 1985) and ruminal effects (Judkins et al., 1991) of frequency and time that supplements are fed have been evaluated with a limited number of forage types. Adams (1985) reported that yearling steers supplemented in the PM $(1330 \mathrm{~h})$ had greater digestible energy intake $(P<0.10)$ 
and ADG $(P<0.01)$ than the AM-supplemented $(0730 \mathrm{~h})$ group. The steers were grazing Russian wild ryegrass (Elymus junceus L.) only $(6.6 \% \mathrm{CP})$ or supplemented with corn $(0.3 \%$ of $\mathrm{BW})$ either in the AM or PM. Although supplemented steers did not graze for two to four $\mathrm{h}$ after supplementation, animal performance was not affected. Leonard et al. (1989) reported that form $(P<0.08)$ and not time $(P>0.10)$ of feeding corn grain influenced animal performance, ADG and passage characteristics of beef steers offered fescue hay. Wiley et al. (1991) reported that in situ NDF disappearance rates of supplements containing DL-methionine fed to cows at 1200 or $1500 \mathrm{~h}$ were greater $(P<0.01)$ than those supplemented at 0800 h. In this study, cows were fed hay only $(8.6 \% \mathrm{CP})$ or supplemented with DL-methionine at 0800 , 1200 , or $1500 \mathrm{~h}$. The increased rate and extent of DM and NDF disappearance occurred possibly through increased microbial fermentation because of the synchronous availability of $\mathrm{N}$ and $\mathrm{CHO}$ for rumen microbes at 1200 or $1500 \mathrm{~h}$, as opposed to $0800 \mathrm{~h}$. The authors concluded that the favorable ruminal responses to supplemental DL-methionine depended on time of supplementation. In contrast, McCracken et al. (1993) reported that daily supplemental methionine $(11.4 \mathrm{~g} /$ steer $)$ increased $(P<0.05)$ the rate of NDF digestion of steers grazing low quality fescue (Festuca arundinacea L.) fed at $0700 \mathrm{~h}$ but not at $1200 \mathrm{~h}$. However, forage intake and ruminal fermentation kinetics were not altered $(P>$ 0.10 ) by time of supplementation. The disparity in results between this study and that of Wiley et al. (1991) may be that carbohydrates were more readily 
available with the actively growing forage compared to the low quality hay used in the study of Wiley et al. (1991).

Robinson et al. (1997) reported that lactating dairy cows fed a protein supplement (47.4\% CP) during the night (0030 h, $7.5 \mathrm{~h}$ after the evening meal) had greater apparent fore-stomach digestion $(P<0.05)$ of OM (42.5 vs $36.6 \%)$ and $\mathrm{CP}(11.8$ vs $-2.3 \%)$ than cows fed the supplement during the day (0830 $\mathrm{h}$, $0.5 \mathrm{~h}$ after the morning meal). The meal was a mixture alfalfa silage, whole crop oat silage, and concentrate consisting of primarily barley grain $(12.8 \% \mathrm{CP})$. Volatile fatty acid (except isobutyrate) concentration was greater whereas flow of nonbacterial NAN (as a proportion of $\mathrm{N}$ intake) to the duodenum was lower $(P<$ 0.05) for cows fed protein supplement during the night compared to cows fed the supplement during the day. These results support the view (Robinson et al., 1987; Ulyatt et al., 1984) that protein fed during the night stimulates ruminal fermentation (at night), resulting in greater fore-stomach OM digestion and less escape of dietary protein from the fore stomach. Shabi et al. (1998) reported that mean daily ruminal $\mathrm{NH}_{3}-\mathrm{N}$ concentration was reduced by high ruminally degradable $\mathrm{OM}$, low ruminally degradable $\mathrm{CP}$, and twice daily feeding (at 0600 and $1800 \mathrm{~h}$ ). In addition, a high concentration of ruminally degradable OM at a high feeding frequency (four times daily at $0600,1200,1800$, and $2400 \mathrm{~h}$ ) resulted in lower fluctuation of ruminal $\mathrm{NH}_{3}-\mathrm{N}$.

In contrast, several reports indicate either minimal or no animal response to time of energy or CP supplementation. Reports of Barton et al. (1992) found 
minimal differences in intake and digestibility between steers supplemented with cottonseed meal (CSM) at the rate of $0.25 \%$ of BW at 0600 or $1200 \mathrm{~h}$; however, supplementation enhanced intake and digestibility of dormant intermediate wheat grass. The authors concluded that morning supplementation created greater spikes of ruminal $\mathrm{NH}_{3}$ concentration than afternoon supplementation did, albeit with little influence on ruminal fermentation. Judkins et al. (1991) reported similar observations in that forage DMI, bacterial synthesis, ruminal kinetics and ADG were not influenced $(P>0.05)$ by time of protein supplementation. In this study, four ruminally cannulated steers were fed low quality fescue hay $(6.1 \% \mathrm{CP})$ only or hay supplemented with CSM at $1.6 \mathrm{~g} / \mathrm{kg}$ BW once daily at 0600,1000 or $1400 \mathrm{~h}$. However, steers supplemented with CSM had greater ADG $(P<0.05)$ over the unsupplemented group.

Hunt et al. (1989) reported that DM and NDF intake of low-quality grass hay $(6.6 \% \mathrm{CP})$, NDF and ADF in situ disappearance and ruminal VFA concentrations were greater $(P<0.05)$ when CSM was fed as opposed to control (no CSM); however, time of feeding CSM (at $12 \mathrm{~h}, 24 \mathrm{~h}$ or $48 \mathrm{~h}$ ) did not affect ( $P$ $>0.10$ ) these variables. Cottonseed meal was fed to provide $3 \mathrm{~g} \mathrm{CP} / \mathrm{kg} \mathrm{BW}^{0.75}$ daily. The authors suggested that the time interval of feeding supplemental protein is not critical for steers consuming forage high in DIP. It appears that the time of feeding a protein supplement has minimal associative effects compared to type and quantity of supplement. 


\section{Synchronization of ruminal energy and $\mathrm{N}$}

Synchronization refers to the combination of carbohydrate and CP sources with similar ruminal degradation resulting in a more efficient utilization of energy and $\mathrm{N}$ in ruminant diets. Synchronous supply of $\mathrm{N}$ and energy substrates is one way to achieve a stable ruminal environment (Sinclair et al., 1993). Microbial growth and protein synthesis can be stimulated by stable ruminal kinetics (Khorasani et al., 1994; Sniffen and Robinson, 1987) and by reducing feedrelated associative effects in the rumen (Robinson, 1989).

Synchronization of the rate of carbohydrate fermentation and protein degradation has been suggested as a means to optimize microbial growth in the rumen (Hoover and Stokes, 1991) and improve the capture of rumen degradable CP (Johnson, 1976; Nocek and Russell, 1988). Despite the efficient synthesis of microbial protein from diets consisting of high quality pasture, pre-duodenal losses of $\mathrm{N}$ can account for up to $30 \%$ of ingested $\mathrm{N}$ (Beever and Siddons, 1986). This loss of $\mathrm{N}$ occurs when concentrations of ruminal $\mathrm{NH}_{3}$ are high because of the rapid and extensive ruminal degradation of pasture $\mathrm{N}$ (Beever and Siddons, 1986; van Vuuren et al., 1991). Rook et al. (1994a) attributed increased $\mathrm{N}$ loss observed to inconsistent diurnal pattern of DMI by intensively grazed dairy cows. Van Vuuren et al. (1990) suggested that, for optimal utilization of pasture $\mathrm{N}$, supplemental carbohydrate should theoretically have a degradation rate similar to that of pasture $\mathrm{N}$ ( 8 to $14 \% / \mathrm{h}$ ) or ratio of $25 \mathrm{~g}$ of $\mathrm{N} / \mathrm{kg}$ of OM fermented. 
Sinclair et al. (1993; 1995) reported improved efficiency of ruminal microbial synthesis by maintaining proper hourly amounts and ratios of the available carbohydrate and $\mathrm{N}$ supplies in the rumen. When dietary concentrations of ruminally degradable carbohydrate and protein were matched, concentration of ruminal metabolites (Stokes et al., 1991) or milk yield and composition (Aldrich et al., 1993; Casper and Shingoethe, 1989; Herrera-Saldana et al., 1990a) were altered. Synchronous ruminal release of supplemental carbohydrate with pasture $\mathrm{N}$ appeared to improve the capture of ruminal $\mathrm{N}$ (Kolver et al., 1998). However, $\mathrm{N}$ retained for milk production and growth, milk yield, composition or efficiency, was not influenced by treatment. Increased capture of excess $\mathrm{N}$ may have other physiological effects. The energy cost associated with metabolic disposal of excess $\mathrm{N}$ has been proposed to be $0.2 \mathrm{Mcal}$ of net energy for lactation per $100 \mathrm{~g}$ of CP consumed (Twigg and Gils, 1998). In addition, adverse effects of excess $\mathrm{N}$ on reproductive performance (decreased fertility, increased embryonic mortality and increased number of days open) are well documented (NRC, 2001).

In other reports, attempts to synchronize ruminal nonstructural carbohydrates and CP degradability have produced minimal benefits for dairy cows in mid lactation. Henning et al. (1993) reported that the degree of energy and $\mathrm{N}$ synchronization affected neither microbial flow nor efficiency of growth, thus suggesting that merely improving degree of synchronization between energy and $\mathrm{N}$ release rates in the rumen does not always increase microbial 
yield. Robinson and McQueen (1994) reported that synchronization of ruminal fermentation of dietary carbohydrate and $\mathrm{N}$ had no effect on ruminal VFA concentration or overall milk yield of dairy cows. Despite synchronized availability of OM and CP, Robinson (1989) observed large fluctuations in ruminal metabolite concentrations when large amounts of rapidly fermentable supplements were fed, resulting in a lower ruminal $\mathrm{pH}$ and reduced microbial synthesis. Dietary manipulation priority should aim to obtain an even ruminal energy supply and provide the appropriate amount of ruminally available N (NRC, 2001). An even ruminal $N$ supply, avoiding too rapid a ruminal $N$ release, should also be considered in the formulation of supplements.

\section{Grazing behavior}

The grazing process is a complex set of events initiated by the grazing animal in response to hunger (Forbes, 1988). The animal responds to hunger by searching an appropriate feeding station and allocating time to the ingestion process (prehension, biting, manipulation/chewing and swallowing). This process is repeated over in several bouts until the animal receives a satiety signal to stop eating or fatigue limits further grazing activity (Forbes, 1988; Hodgson, 1990; Stobbs, 1973). Other activities associated with grazing include rumination process (regurgitation, re-chewing, and swallowing of feed bolus) and idling/resting. The behavior of grazing animals on pasture is generally responsive to forage conditions, mainly allowance and quality (Hodgson, 1990). 


\section{A. Behavior characteristics}

Bite size, biting rate, grazing time and rumination time generally characterize grazing behavior. According to Hodgson (1990), bite size is the dominant animal variable affecting forage intake. A small bite size is indicative of limiting forage conditions. Bite size rapidly declines once sward height falls below certain threshold height, $4 \mathrm{~cm}$ for cattle (Rook et al., 1994a) and $3 \mathrm{~cm}$ for sheep (Hodgson, 1990). Bite size varies widely with type and stage of growth of the forage being grazed. For temperate grasses, bite size linearly increases with sward height until leaf density begins to decline as flower horizons appear (Forbes, 1988). Stobbs (1973) suggested that forage intake by cows grazing tropical grass swards might be restricted if mean bite size fell below $0.30 \mathrm{~g} \mathrm{OM}$. Leaver (1986) reported that at a bite size of $0.65,0.45$ and $0.25 \mathrm{~g} \mathrm{DM}$, depression from maximum herbage DM intake decreased by $0.8,3.4$ and $8.1 \mathrm{~kg}$ DM/d, respectively. On average, most cows take 36,000-40,000 bites/d and 3575 bites/minute (Chacon et al., 1978), depending on height and density of pasture.

Animals generally tend to compensate for reduced bite size by increasing the biting rate or grazing time (Chacon et al., 1978; Henricksen and Minson, 1980; Forbes and Coleman, 1987) or both (Philips and Leaver, 1985). However, fatigue on the part of the grazing animal may limit the extent to which biting rate and/or grazing time can be increased (Rook et al., 1994a). Grazing time is one of the limiting factors controlling intake when forage availability is low (Rook et 
al., 1994a). An animal that needs less forage to meet its energy requirements will require less time to consume its desired level of DM from pasture. Consequently, the forage height necessary to maximize performance would be lower for concentrate-supplemented cows than for unsupplemented cows (Gekara et al., 2001).

Philips and Leaver (1985) reported that rumination time tended to be lower in early spring and late summer $(6.5 \mathrm{~h} / \mathrm{d})$ compared to mid summer $(7.8$ $\mathrm{h} / \mathrm{d}$ ), indicative of seasonal variation in forage fiber content. The authors suggested that low forage fiber content and low herbage intake may have contributed to the rumination times observed for early spring and late summer, and mid summer, respectively. The authors further reported that rumination activity was concentrated in the night hours and also interspersed between the major grazing bouts in the daytime.

B. Selective grazing

Ruminants are selective grazers, thus, the nutrient content of the pasture consumed is usually greater than that of the pasture offered (Minson, 1990). Selective grazing strategy is employed by animals to discriminate against forage parts or plants deemed unsavory, dead, mature or poor in quality. Leaves and leafy stems devoid of dead material are selected over mature and flowery stems as well as legume over grass (Minson, 1990). However, animals grazing more selectively travel longer distances as they spend more time search grazing (Krysl and Hess, 1993). In addition, animals grazing selectively generally allocate 
more time to grazing activity at the expense of other productive activities such as rumination and resting (Rook et al., 1994a).

Depending on animal species, differences in grazing behavior and diet selection can influence the structure of a sward. The composition and structure of a grazed sward is a result of the competitive interactions between the plant species (for light and nutrients) and degree of defoliation. Thus, forage composition and structure is determined by the degree of animal selectivity and grazing pressure (Schwinning and Parsons, 1996). Higher white clover content tended to develop in grass/white clover swards when grazed by cattle compared with sheep (Briseño de la Hoz and Wilman, 1981), or goats compared with sheep (Penning et al., 1996). The observed response was probably a function of the mechanics of animal grazing behavior in relation to sward canopy structure. Active selection may have played a role in reducing the proportion of clover in pastures grazed by sheep as opposed to cattle. Studies of Milne et al. (1982) showed a higher proportion of clover in the diet selected by sheep compared with cattle and goats. Wright et al. (2001) reported that grazing grass/clover swards by cattle followed by sheep resulted in a higher proportion of white clover in the diet of both species, thus, herbage intake for both species tended to be higher. 


\section{Grazing management}

Seasonal variation in pasture conditions, mainly quality and quantity, is an important consideration for undertaking a system of managing pastures and grazing animals to ensure animals have access to an ample supply of good quality forage year round.

A. Grazing system

Rotational and continuous stocking are common management systems for grazing dairy and beef cattle. In rotational grazing, animals are rotated between grazing and resting of pastures, subdivided into at least two paddocks. In continuous stocking, animals remain on the same pasture throughout the grazing season. Williams and Hammond (1999) reported that animal performance as determined by ADG, body condition score, pregnancy rate, and adjusted 205-d weaning weight of calves, was not affected when continuous or rotational grazing management were compared. For both systems, herbage mass and quality of forage (in vitro OM digestibility and CP concentrations) did not change $(P>0.10)$. The authors concluded that the main advantages of continuous over rotational grazing management are less labor and fencing costs, and reserving an area for production of winter feeds.

In either rotational or continuous grazing systems, optimal stocking rate (number of animals per unit area of pasture) is important from the standpoint of animal and pasture production (Hodgson, 1990). Baker et al. (1981) reported that milk yield and ADG of cow/calf units was affected by the severity of grazing 
induced in set-stocking pastures. Increasing the stocking rate from low $(3.33 / \mathrm{ha})$ to medium $(3.81 / \mathrm{ha})$ reduced daily milk yield, cow and calf gain by $1.1,0.14$ and $0.09 \mathrm{~kg} / \mathrm{d}$, respectively, and from medium to high ( $4.44 / \mathrm{ha})$ by 1.3 , 0.24 and $0.03 \mathrm{~kg} / \mathrm{d}$. The authors concluded that pasture management decisions should be based on the cow rather than calf performance since the calf is buffered against the effects of herbage allowance by cow milk.

Frame and Dickson (1985) reported that herbage digestibility increased and dilution of re-growths by residual aging herbage was reduced as stocking rate increased. However, the benefits that farmers can expect from more intensive grazing management are more evident in a year of good pasture growth (Bryan et al., 2000).

B. Sward management

The primary goal of a producer in forage management is to maintain forage quality at a level that will support desired levels of gain or milk production. Thus, sward management should aim to optimize herbage utilization and at the same time provide a sward able to withstand repeated defoliation throughout the season. Sward management such as rest-period interval, stubble height, and other factors that affect forage quality may depend on type of forage. Jones (1985) reported that warm season grasses are generally lower in quality (CP and digestibility) than temperate genera due to a relatively low leaf to stem ratio, rapid rates of maturation, and chemical and physical characteristics associated with $\mathrm{C}_{4}$ photosynthetic pathway. 
Re-growth of a sward following defoliation may depend on frequency, intensity, and timing of defoliation. Two aspects of defoliation management that can be readily varied in a rotational stocking system are frequency and intensity, and both can have an effect on pasture production (Bryan et al., 2000). Frequency refers to time intervals between successive defoliations while intensity refers to the severity of defoliation. Frequency of defoliation could be considered in relation to developmental phases of plants and season of the year (Harris, 1978). Severe defoliation which may involve removal of growing points and treading of a sward requires a longer recovery period especially late in the grazing season when growth rate is slow (Harris, 1978). Re-growth period may also depend on the growth habit of the sward (Pearson and Ison, 1997). For instance, stoloniferous plants could require longer recovery periods following defoliation since their growing points are more prone to the effects of treading (Harris, 1978).

Time required for re-growth to attain a sward height that provides optimal herbage mass, quality, and animal performance, varies. Prevailing weather conditions, canopy tissue demography (leaf, stem, and senescence tissue), nutrient availability, residual height after defoliation, and developmental stage may influence recovery from defoliation (Belesky and Fedders, 1994). Mayne et al. (1987) showed that grazing intensely early in the season (to $6 \mathrm{~cm}$ sward height) resulted in better sward structure late in the season and improved grassland utilization. The authors concluded that in a rotational grazing system, 
a reasonable compromise between sward utilization and animal performance could be achieved by grazing spring-calving dairy cows to a residual sward height of $6 \mathrm{~cm}$. Bryan and Mills (1988) reported that more herbage was produced from a Kentucky bluegrass/white clover sward cut to simulate rotational re-growth (4-wk re-growth interval) than from a sward managed for hay. Repeated defoliation ( $50 \%$ and $70 \%$ removal) of orchardgrass (Dactylis glomerata L.), tall fescue (Festuca arundinacea L.) x perennial ryegrass hybrid and prairie grass (Bromus unioloides L.) resulted in more stable distribution of herbage within a season although herbage mass was smaller compared with canopies managed as hay (Belesky and Fedders, 1994). Grazing management strategies including optimal stocking rate and sward management are crucial if optimum animal and pasture productivity is to be achieved.

Agronomic practices such as grazing management, application of fertilizer and improvement of pastures are a prelude to an ample supply of high quality forage (Pearson and Ison, 1997). Use of fertilizer, mainly N, P and K, is a management practice often used to increase forage productivity (quality and quantity) particularly when soils are deficient in these essential nutrients (Pearson and Ison, 1997). Nitrogenous fertilizer can improve the CP content of some forages resulting in increased intake of up to $70 \%$, however, this effect may be related to stage of forage maturity (Minson, 1990). Similarly, grass/legume mixtures can increase the $\mathrm{N}$ content of forage (Marshall et al., 
1998) because legumes fix atmospheric $N$ that grasses readily utilize, enhancing their $\mathrm{N}$ content. 


\section{CHAPTER 3: INTRODUCTION}

When cattle consume forages as their only energy source, intake of available energy may be inadequate to meet desired production demands. To increase milk production, supplementation (with concentrates) of lactating dairy cows under grazing situations is a viable option (Kolver and Muller, 1998). Gekara et al. (2001) reported that concentrate supplementation of cows grazing lower sward height $(6.6 \mathrm{~cm})$ pasture resulted in greater forage DMI compared to cows on higher sward height $(8.8 \mathrm{~cm})$ pasture. This suggests that pasture management could be an important variable influencing the effectiveness of supplementation.

Gekara et al. (2001) further reported that forage intake and digestibility of grazing cows decreased as the level of supplement increased from 0 to $1.2 \%$ of BW. Declining forage intake and digestibility could be attributed to disruption of the rumen environment via fluctuations in $\mathrm{pH}$, microbial types and/or population (Hoover, 1986; Mould and Ørskov, 1984). Moreover, the grazing intensity of cattle varies throughout the day partly in response to environmental temperature, demand for other activities such as rumination and resting (Rook et al., 1994a) or to diurnal changes in nutrient composition of pasture (Orr et al., 1997) and/or rumen metabolites (Van Vuuren et al., 1986). Because of diurnal changes in the ruminal environment brought about by the grazing pattern of cattle, the effectiveness of concentrate supplements on pasture could be influenced by time of concentrate feeding via effecting fiber digestion and other 
variables associated with ruminal fermentation. Consequently, the objective of this study was to determine the effect of sward height, timing of concentrate supplementation and grazing time management on pasture utilization of lactating beef cows as a model for dairy cattle. 


\section{CHAPTER 4: MATERIALS AND METHODS}

\section{Experimental Design}

The experiment was conducted at the West Virginia University Animal Science Farm, Morgantown, during the 2000 grazing season on naturalized coolseason grass pastures. The experimental area has a slope of $15-20 \%$ and soil types were: Clarksburg (fine-loamy, mixed, mesic Typic Fragiudalfs); Dormont (fine-loamy, mixed, mesic ultic Hapludalfs) and Holly (fine-loamy, mixed, non acid, mesic Typic Fluvaquents). No lime or fertilizer was applied. Thirty-two multiparous crossbred (24 Angus and 8 Hereford) beef cows (632 $\pm 14 \mathrm{~kg} \mathrm{BW}$ )

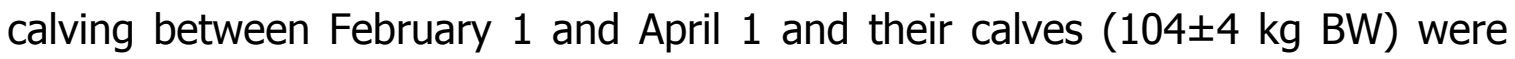
grouped according to calving date and body weight. They were randomly assigned two sward height (SH) treatments (4 to 8 or 8 to $12 \mathrm{~cm}$ ), replicated four times. Each cow received a concentrate supplement $(4.1 \mathrm{~kg} \mathrm{DM} / \mathrm{d})$ fed at one of two different times (T), either at $0700 \mathrm{~h}(\mathrm{AM})$ or $1800 \mathrm{~h}(\mathrm{PM})$, and either restricted (R) to grazing $12 \mathrm{~h} / \mathrm{d}(0700$ to $1900 \mathrm{~h}$ ) or unrestricted $(\mathrm{U})$ to $24 \mathrm{~h} / \mathrm{d}$ grazing management (MGT). The R grazing management was incorporated to simulate a dairy system where cows would be allowed to graze one period daily between milking. The experiment was conducted over three periods, each lasting 15 days: May 5 - May 26 (period 1), June 29 - July 13 (period 2) and August 15 - August 29 (period 3). The experimental cow/calf units grazed on the same plots during all three experimental periods, but were re-randomized within the T or grazing management treatments during each period. 


\section{Animals and Diet}

Before the start of period 1, all animals were fitted with fly control ear tags (Cutter blue, Bayer Corp., Shawnee, KS) and treated for internal parasites using Safe-Guard (Hoechst Roussel Vet, Summersville, NJ). Protocol approved by the University Animal Care and Use Committee was applied in the management of animals and experimental procedures. Animals were weighed at the beginning and end of each experimental period. Cows were fed the supplements individually in $2.5 \mathrm{~m} \times 0.8 \mathrm{~m}$ stalls located within each plot. Stalls were also used for placement and removal of vibracorders, feeding of a fecal output marker and collection of fecal samples. Animals were usually in the stalls for less than fifteen minutes twice daily for these procedures.

The concentrate supplement was offered in one portion at the prescribed feeding time throughout the $15-\mathrm{d}$ experimental period. To ensure uniform distribution of the marker $(\mathrm{Yb})$ in the feces, $\mathrm{Yb}$-labeled oats were fed twice daily. The labeled oats were mixed with the supplement at the prescribed supplementation time or mixed with a portion of the supplement $(100 \mathrm{~g})$ and fed to cows not receiving supplement at that particular time to encourage consumption. The supplement was comprised of mainly corn and soybean meal, and its composition and nutritive value are reported in (Table 1). All animals were allowed free access to a trace mineralized salt block ${ }^{1}$ (Morton International, Inc. Chicago, IL) and water.

${ }^{1} 95-98 \% \mathrm{NaCl}, 0.35 \% \mathrm{Zn}, 0.28 \% \mathrm{Mn}, 0.175 \% \mathrm{Fe}, 0.035 \% \mathrm{Cu}$, and $0.007 \% \mathrm{Co}$ 
Cattle on restricted grazing management were removed from the plots at $1900 \mathrm{~h}$ and confined in nearby holding pens (supplied with drinking water only) where they remained overnight and were returned to their specific plots for grazing at $0700 \mathrm{~h}$.

The naturalized pasture was comprised of grasses, predominantly Kentucky bluegrass (Poa pratensis L.) and some orchardgrass (Dactylis glomerata L.); legumes, predominantly white clover (Trifolium repens L.) and some red clover (Trifolium pratense L.); weeds were mainly broad-leaved. Nonexperimental yearling cattle of similar breeding as the cows were used on a put and take basis throughout the grazing season to maintain the swards at the desired heights. Appropriate adjustments in yearling cattle numbers were made weekly. Between periods, the experimental cow-calf units were moved to nonexperimental pastures of similar type.

\section{Sampling Procedure}

Pasture conditions were monitored weekly throughout the grazing season by taking sward height (SH) measurements (50 readings/plot) using an acrylic plastic meter as described by Rayburn and Rayburn (1998). Only measurements collected during the experimental period are reported in this experiment. Clip samples to determine botanical composition and growth rate of pasture, pluck samples of forage representing the grazed horizon and fecal grab samples to determine fecal output were collected twice daily at the same time as feeding and analyzed as described by Gekara et al. (2001). Clip 
samples were collected once every two weeks for the entire grazing season; pluck samples were taken every two days starting d 9 through d 13 and fecal grab samples were collected twice daily at the time the supplement was fed starting d 10 until d 14 of each $15 \mathrm{~d}$ experimental period. Dried samples were ground in a Wiley mill (Thomas Scientific, Swedensboro, NJ) to pass through a 1$\mathrm{mm}$ screen. The samples were subsequently analyzed for dry matter (DM), crude protein (CP), neutral detergent fiber (NDF), acid detergent fiber (ADF), and alkaline peroxide lignin (APL).

\section{Measurements and Analytical Methods}

To allow comparison with other investigations, sward surface height (SSH) using the Hill Farming Research Organization (HFRO) sward stick (Barthram, 1986) was calculated from the SH obtained using the acrylic plate disc meter. The following prediction equation, developed from paired samples ( $\mathrm{SH}$ and $\mathrm{SSH}$ ) taken on experimental pastures in 2001 using the method of Bryan et al. (1990), was used:

$\mathrm{SSH}(\mathrm{cm})=1.1851 \times \mathrm{SH}(\mathrm{cm})-0.6011, \mathrm{R}^{2}=0.90$

The relationship between sward height and herbage mass was estimated from the equation developed from paired samples (plate height and herbage DM) taken on experimental pastures in 2001 using the method of Bryan et al (1990).

Herbage mass $(\mathrm{kg} / \mathrm{ha})=229.14 \times \mathrm{SH}(\mathrm{cm})+348.38, \mathrm{R}^{2}=0.60$

Herbage growth rate was determined using exclusion cages (four per paddock) as described by Gekara et al. (2001). 
Dry matter and $\mathrm{CP}$ of the pluck samples were analyzed according to procedures described by AOAC (1990). Neutral detergent fiber and ADF were analyzed following procedures described by Van Soest et al. (1991) and Robertson and Van Soest (1981), respectively. In vitro dry matter digestibility (IVDMD) of the supplement was determined as described by Goering and Van Soest (1970), using a ruminal fluid inoculum obtained from a ruminally cannulated dry dairy cow grazing a similar type of pasture.

Ytterbium (Yb) was used as an external indicator to estimate fecal output. Ytterbium labled oats were prepared by spraying $\mathrm{YbCl}_{3}$ solution on whole oats according to procedures described by Baker et al. (1988). Each cow received $100 \mathrm{~g}$ of Yb-labeled oats/d (as fed) starting day 1 until d 14 of each period (50 g at each feeding). Samples of the composited feces and labeled oats were analyzed for $\mathrm{Yb}$ concentration according to procedures of Baker et al. (1988). Fecal output (DM basis) was calculated from indicator concentrations using the following formula:

$$
\text { Fecal output }(\mathrm{g} / \text { day })=\frac{\text { Indicator dose, } \mathrm{mg} / \text { day }}{\text { Indicator concentration in feces, } \mathrm{mg} / \mathrm{g} \text { feces }}
$$

The contribution of pasture to fecal output was estimated by subtracting the IVDMD indigestible fraction of supplement (0.08) from the total fecal output as described by Gekara et al. (2001) using the following formulae:

Supp fecal output, $\mathrm{kg} /$ day $=($ Supp intake, $\mathrm{kg} /$ day $) \times(1-$ Supp IVDMD $) ;$ IVDMD $=0.92$

Forage fecal output, kg/day $=($ Fecal output, $\mathrm{kg} /$ day $)-($ Supp fecal output, $\mathrm{kg} / \mathrm{day})$ 
To estimate forage intake, alkaline peroxide lignin (APL) content of pasture and feces was used as a marker as described by Sunvold and Cochran (1991). The following formula was then applied:

$$
\text { Forage DMI }(\mathrm{kg} / \text { day })=\frac{(A P L \text { in feces, } \mathrm{kg} / \mathrm{d})-(\mathrm{APL} \text { in suppl., } \mathrm{kg} / \mathrm{d})}{\mathrm{APL} \text { content in forage }(\mathrm{kg} / \mathrm{kg} \text { forage DM })}
$$

Forage digestibility was calculated using the following formula:

$$
\text { Forage digestibility }(\%)=
$$$$
\text { (Forage DMI, kg/d) - (Forage fecal output, } \mathrm{kg} / \mathrm{d} \text { ) }
$$

$$
\text { Forage DMI }(\mathrm{kg} / \mathrm{d})
$$

Grazing time (GT) was measured as described by Gekara et al. (2001) using the vibracorder equipment (Kienzle Apparate Gmbh, Villingen, Germany) fitted around the neck of each cow during each experimental period. The vibracorder remained on the animal for a period of $48 \mathrm{~h}$. An animal was considered either grazing or ruminating/idling if it spent at least 5 continuous minutes doing this activity.

\section{Statistical Analysis}

Forage botanical and chemical composition variables for each paddock were averaged within period and analyzed using the GLM procedure of SAS (SAS Inst. Inc., Cary, NC) using a split plot in time design and replicate $x$ treatment as the error term. Animal variables were analyzed using least squares procedure of SAS and ANOVA based on a split-split plot design with $\mathrm{SH}$ as main plot, supplement feeding time and grazing management in combination as sub-plot treatments and period as sub-sub-plot. Paddock within height and block was 
the error term used to test SH. Cow within height, plot and block tested supplement feeding time and grazing management whereas residual error tested all other independent variables. Fisher's test (LSD) was used to do multiple comparisons among periods. The $F-$ test $(\alpha<0.10)$ was used to determine the effect of $\mathrm{SH}$, supplement feeding time and grazing time management on forage DMI, DM digestibility, digestible DMI, pasture grazing pattern, grazing time and efficiency, and ADG. 


\section{CHAPTER 5: RESULTS AND DISCUSSION}

Weather

Weather data (temperature and precipitation) as reported by the National weather station, Hart Field Airport, Morgantown, WV, was summarized over the grazing season (Table 2). The mean weekly temperature and precipitation during the experimental periods were within normal range for this area. The ambient temperatures were lower for period 1 compared to period 2 and 3, and this was considered normal seasonal variation.

\section{Sward height and herbage mass}

Mean sward height (SH) and sward surface height (SSH) for the low and high swards as well as herbage growth rate and the corresponding herbage mass are shown in Table 3. The SSH difference was $5.6 \mathrm{~cm}$ between the low and high $\mathrm{SH}$ pastures and was what we expected to achieve by varying the grazing pressure. The two measurements for sward height were included to allow for comparison with other literature on the subject. The $\mathrm{SSH}$ is measured without disturbing the canopy of a pasture, whereas to measure SH pressure exerted by the plate disturbs the canopy of a pasture as the height is being taken.

Sward height was found to influence $(P<.05)$ herbage growth rate (Table 3), which was greater for the low compared to the high sward. In a previous study on the same pasture, carrying capacity per ha or stocking density increased as $\mathrm{SH}$ decreased from 12 to $4 \mathrm{~cm}$ as measured by the Hill Farming Research Organization sward stick (Prigge et al., 1997). The results of these 
experiments suggest that a low sward height was needed to optimize forage growth rate for those types of pasture. In the present study, herbage growth rate decreased $(P<.05)$ as the season progressed (Table 4$)$, which was considered to be a normal response due to temperature and moisture limitations (Pearson and Ison, 1997).

\section{Botanical and chemical composition of pasture}

There was no interaction $(P>.10)$ between sward height $(\mathrm{SH})$ and period (P) for the proportion of legume and weeds in the pasture. A SH $\times \mathrm{P}$ interaction $(P<.10)$ for the proportion of grass and dead material was observed. For the high sward height pasture, the proportion of grass decreased (Figure 1) whereas dead material increased (Figure 2) as the season progressed. For the low sward height pasture, the proportion of grass was greater (Figure 1) and the proportion of dead material was lower during P2 (Figure 2) compared to other periods. Forage maturity and the resulting senescence (Hodgson, 1990) probably contributed to these results. During $\mathrm{P} 1$, the high proportion of dead material (for both swards) may have been due to carryover material from the fall (Prigge et al., 1999). During P3, increased maturity and reduced growth rate (Table 4) probably contributed to senescence, especially for the high sward. Sward height influenced $(P<0.10)$ the proportion of legume and weeds (Table 3). Legume proportion was greater for low compared to high SH (6.9 vs 3.9\%). Similarly, the proportion of weeds was greater for the low compared to the high SH (12.7 vs $9.1 \%$ ). Sward height may have influenced the competition between grass 
and legume and/or weeds for resources such as light and soil nutrients (Bullock, 1996). Period had no influence $(P>.10)$ on the proportion of legume and weeds in the sward.

Sward height influenced $(P<.05)$ the concentrations of fiber and $\mathrm{CP}$ in pasture (Table 5). Crude protein decreased whereas NDF and ADF increased as $\mathrm{SH}$ increased, as would be expected with more mature swards (Minson, 1990; Van Soest, 1994). Period influenced the concentration of ADF $(P<.001)$ and $\mathrm{CP}(P<.01) . \quad$ The ADF content of pasture increased (Table 6$)$ as season progressed, as would be expected, again, indicative of increasingly mature forage (Van Soest, 1994). Crude protein concentration was lower in P2 compared to other periods probably because of a proportional increase in fiber content (ADF) over the same period.

Forage and total dry matter intake

There were no three or four-way interactions $(P>.10)$ involving $\mathrm{SH}$, supplement-feeding time, grazing time management and period for forage DMI. An interaction between T and MGT $(P<.05)$ for forage DMI was evident. For cows restricted to $12 \mathrm{~h} / \mathrm{d}$ grazing, supplementing in the AM as opposed to PM (Figure 3) resulted in greater forage DMI ( $8.6 \mathrm{vs} 8.1 \mathrm{~kg} / \mathrm{d}$ ). Cows that were allowed to graze for $24 \mathrm{~h} / \mathrm{d}$ had greater forage DMI when supplemented in the PM as opposed to AM (8.4 vs $8.2 \mathrm{~kg} / \mathrm{d}$ ). A possible explanation for these findings is that cows on restricted management, having been withheld from grazing during the night, perhaps exhibited a compensatory forage intake in the 
AM when most grazing activity occurred. Satiety or rumen fill (Forbes, 1988) may have limited forage DMI for unrestricted cows fed in the AM as opposed to PM. In addition, supplemental nutrients may have influenced forage DM digestibility (Figure 4) of unrestricted cows resulting in increased forage DMI for the PM group compared to AM.

In a study reported by Adams (1985), AM supplemented steers (with corn at $0.3 \%$ of BW $)$ had greater $(P<.05)$ forage DMI than the PM group. The author suggested that steers fed a supplement in the PM probably substituted corn for forage more than the AM supplemented group did. In fact, the PM steers had greater $(P<.10)$ digestible energy intake $(8.4$ vs 7.7 Mcal/100 kg BW) and ADG $(P<.01)$ compared to the AM group probably because of increased intake of total DM. Differences in animal response to feeding time between this study and that of Adams (1985) probably lie in the quality of forages available to animals or perhaps the density of the sward. The ADF and $\mathrm{CP}$ content of forage used in our study was $33 \%$ and greater than $12 \%$, respectively, while in Adams (1985) study it was $48 \%$ and less than $7 \%$, respectively. Adams (1985) did not report forage availability estimate.

Fiber utilization usually increases when ruminal availability of $\mathrm{CHO}$ and $\mathrm{N}$ is synchronous (Hoover, 1986). Studies by Sinclair et al. (1993) concluded that a synchronized supply of $\mathrm{N}$ and energy substrates could achieve a stable ruminal environment (less $\mathrm{pH}$ fluctuation and optimal microbial protein synthesis). Supplying one $(\mathrm{N})$ or both of these nutrients in the PM when amount available 
from forage was probably diminishing or availability in the rumen was limited, may have elicited the animal response (increased intake) observed in this study. Forage digestibility

There was no three or four-way interaction $(P>.10)$ involving $S H, T, M G T$ and period for forage DM digestibility. An interaction between $\mathrm{SH}$ and $\mathrm{T}$ ( $P<$ .05) for herbage DM digestibility was detected. Supplementing in the PM as opposed to AM resulted in greater herbage DM digestibility (67.7 vs $65.4 \%$ ) for cows on high sward height (Figure 4). Cows on low sward height had greater herbage DM digestibility (66.3 vs $64.5 \%$ ) when supplemented in the AM, as opposed to PM. Because the CP content of high sward height forage was lower and fiber content higher than that of low sward height (Table 3), ruminal $\mathrm{NH}_{3}$ levels may have been limiting for optimal fiber digestion at certain times of the day. Supplementing cows on high sward height in the PM, as opposed to AM, may have provided additional ruminal $\mathrm{NH}_{3}-\mathrm{N}$ at times when needed resulting in greater microbial digestion of the forage fiber. Similarly, cows on low sward height and supplemented in the AM, as opposed to PM, had greater DM digestibility compared to cows on high sward height. The lower fiber levels of the low $\mathrm{SH}$ pasture in conjunction with a slower rate of fiber consumption as one would expect on a pasture of lower SH (Rook et al., 1994a) may have resulted in the AM supplement having less of a $\mathrm{pH}$ related inhibition of ruminal fiber digestion (Hoover, 1986). In addition, diurnal fluctuations of forage nutrients 
(Younberg et al., 1972) could have also contributed to the digestibility response observed in this study by influencing the ruminal environment.

Microbial growth and protein synthesis can be stimulated by stable ruminal fermentation with a constant supply of fermentation substrate and nutrients (Khorasani et al., 1994; Sniffen and Robinson, 1987). In our study, it is possible that $\mathrm{N}$ and energy synchronization may have been achieved at different times for each forage height, AM for low sward height and PM for high sward height. Measurements of ruminal fermentation variables (mainly $\mathrm{NH}_{3}-\mathrm{N}$ concentration) collected over time on pastures of this type (Hess et al., 1996) support these explanations.

Digestible dry matter intake

There were no three or four-way interaction $(P>.10)$ involving sward height, supplement feeding time, grazing time management and period for forage digestible DMI (DDMI). An interaction, supplement feeding time $\mathrm{x}$ grazing time management $(P<.10)$, for forage DDMI was apparent. Cows restricted to $12 \mathrm{~h} / \mathrm{d}$ grazing consumed a greater amount of forage digestible DM (Figure 5) when supplemented in the AM as opposed to PM (5.0 vs $4.7 \mathrm{~kg} / \mathrm{d}$ ) mainly due to increased forage DMI (Figure 3). Cows that were unrestricted had greater forage DDMI (4.9 vs $4.6 \mathrm{~kg} / \mathrm{d}$ ) when supplemented in the PM as opposed to AM. Unrestricted cows had greater forage DDMI when supplemented in the PM compared to AM most likely because of enhanced or 
less inhibition of forage digestibility (Figure 4) whereas satiety or rumen fill (Forbes, 1988) probably limited forage DDMI for the AM supplemented cows.

Insufficient intake of digestible nutrients, mainly because of increased consumption of slowly degradable fiber, could restrict the productivity of grazing ruminants (Minson, 1982). Forage DMI is limited by mainly fill with slowly digestible feeds, thus, animals with high energy requirements consuming relatively low energy, high fill diets are affected to the greatest extent (Allen, 1996). The characteristics that contribute most to intake of forage include solubility or cell content of pasture, insoluble but potentially fermentable fraction, degradation rate, rumen outflow rate and rate of particle size reduction (Ørskov and Fraser, 1975). These factors may have contributed to the animal responses in forage DDMI observed in this study.

\section{Pasture grazing pattern}

In this study, grazing intensity of cows was mainly concentrated in the mid morning (0700 to $1000 \mathrm{~h}$ ) and early evening between 1800 and $2000 \mathrm{~h}$ (Figure 9 and 10) generally agreeing with other reports (Stobbs, 1970; Rook et

al., 1994a). For ruminants grazing cool season pastures, two main grazing bouts (meals) lasting 2 to $4 \mathrm{~h}$ occur in the mid morning (0700 to $1000 \mathrm{~h}$ ) and early evening between 1800 and 2000 h (Rook et al., 1994a). Most grazing activities of cattle take place during the daytime ( $>87 \%$ ) and the rest at nighttime (Stobbs, 1970; Rook et al., 1994a). Penning et al. (1991b) suggested that the large evening meal could be an optimal foraging response to build up of 
readily digestible products of photosynthesis in plant leaves at this time. The large mid morning meal could be attributed to animal response to reduced gut fill (Forbes, 1988) and low ambient temperature (Seath and Miller, 1946), especially during the summer months.

In examining the diurnal nutrient variation in pasture, Holt and Hilst (1969) found that water-soluble carbohydrates of cool season forages increased linearly from $0600 \mathrm{~h}$ to $1800 \mathrm{~h}$ and nonstructural polysaccharides (mainly starch) followed a non-linear trend peaking in the afternoon. Youngberg et al. (1972) reported that total $\mathrm{N}$, water soluble $\mathrm{N}$ and amino acid $\mathrm{N}$ in alfalfa leaves and stems were highest between 0300 and $0600 \mathrm{~h}$ and declined throughout the day. Time of supplementation of grazing cattle in relation to the daily pasture consumption pattern as well as the diurnal change in pasture composition could influence the intake and digestibility variables reported in this study, by providing substrates that could inhibit (i.e. decrease ruminal $\mathrm{pH}$ ) or enhance (i.e. $\mathrm{NH}_{3}-\mathrm{N}$ ) fiber digestibility or metabolites that could influence voluntary intake (i.e. VFA's).

Sward height did not influence $(P>.10)$ the grazing pattern of cows (Figure 10). This observation was somewhat surprising as cows on low sward height were expected to allocate more time to grazing activity compared to those on high sward height to make up for the smaller bite size. This usually is the case with ruminants grazing low swards (Rook et al., 1994a; Penning et al., 1991a). The grazing pattern was not disrupted following supplementation (Figure 9 and 10) contrasting with other reports (Adams, 1985). In the study 
reported by Adams (1985), steers grazing native pasture and supplemented with concentrates (at 0730 and $1330 \mathrm{~h}$ ) did not graze for about two to four hours following supplementation. Disparity in forage quality may be responsible for the differences in results observed between the two studies.

Grazing time management influenced $(P<.05)$ the grazing pattern of cows. Cows restricted to $12 \mathrm{~h} / \mathrm{d}$ grazing grazed with greater intensity throughout the day compared to unrestricted cows (Figure 9) probably because the stimulus for intake was more intensive. Cows restricted to $12 \mathrm{~h} / \mathrm{d}$ consumed greater $(P<.05)$ amounts of forage DM (Figure 3$)$ and digestible DM (Figure 5) when supplemented in the AM as opposed to PM. Unrestricted cows consumed greater amounts of forage DM and digestible DM when supplemented in the PM as opposed to AM. Increased forage DMI observed in the AM for restricted cows and PM for unrestricted cows (Figure 3) was possibly related to diurnal changes in forage DMI and/or nutrient composition in pasture, mainly energy and $\mathrm{N}$.

\section{Grazing time and efficiency}

Three or four-way interactions involving $\mathrm{SH}, \mathrm{T}, \mathrm{MGT}$ and period for grazing time ( $\mathrm{h} / \mathrm{d}$ ) and grazing efficiency ( $\mathrm{kg}$ forage DMI/h of grazing time) were not evident $(P>.10)$. However, an interaction between T and MGT for grazing time was apparent $(P<.10)$. Supplementing in the PM as opposed to AM, increased the actual time spent grazing to a greater extent for cows restricted to $12 \mathrm{~h} / \mathrm{d}$ grazing than for unrestricted cows (Figure 6). Supplementing in the AM, 
as opposed to PM, had greater grazing efficiency (DM intake/h of grazing time) for cows restricted to $12 \mathrm{~h} / \mathrm{d}$ grazing (Figure 7) compared to unrestricted cows (1.3 vs. $1.2 \mathrm{~kg} \mathrm{DM} / \mathrm{h}$ of grazing time). Therefore, the decrease in grazing time for restricted cows was compensated by an increase in grazing efficiency (Figure 7). Cows restricted to $12 \mathrm{~h} / \mathrm{d}$ probably grazed with greater intensity (Figure 9) compared to unrestricted cows, in response to a stimulus initiated by low rumen fill following a 12-h lapse of no grazing activity. This would suggest that less selectivity occurred for higher quality components of the pasture (Minson, 1990) by the restricted compared to unrestricted cows. However, the methodology of using pluck samples to represent quality of herbage consumed in this study would not be sensitive enough to detect these differences.

An interaction between $\mathrm{SH}$ and period $(P<.05)$ for grazing time was evident. Cows grazing low sward height pasture allocated more time to grazing activity during P1 compared to P2 and P3 (Figure 8). Cows grazing high sward height pasture spent more time grazing during P1 and P2 compared to P3. The decreased grazing time observed for the later periods (for both groups) was possibly related to the high ambient temperatures at this time of the year and a decline in nutrient requirements for the cows in the later stages of lactation.

\section{Average daily gain}

Although average daily gain (ADG) was measured over short durations, the results can perhaps relate to the differences observed in intake and digestibility. There were no three or four-way interactions $(P>.10)$ involving 
$\mathrm{SH}, \mathrm{T}, \mathrm{MGT}$ and period for ADG of both cows and calves. There were no twoway interactions $(P>.10)$ involving $\mathrm{SH}, \mathrm{T}, \mathrm{MGT}$ and period for the ADG of calves. An interaction between $\mathrm{SH}$ and $\mathrm{T}(P<.10)$ for ADG of cows was apparent. Supplementing in the PM as opposed to AM increased ADG (Figure 10) of cows on high sward height when compared to those on low sward height, probably because of increased forage DM digestibility (Figure 4) and possibly DMI (Figure 3). In addition, supplemental nutrients fed at this time (PM) may have enhanced animal performance. However, time of supplementation did not influence $(P>.10)$ cow gain for either SH treatment. The greater forage DMI and DDMI for cows restricted to $12 \mathrm{~h} / \mathrm{d}$ grazing and supplemented in the AM as opposed to PM (Figure 3) was not reflected in ADG perhaps due to the short duration of the experiment and gut fill differences at the AM weighing time.

Adams (1985) reported that ADG was greater $(P<.01)$ for PM supplemented steers than for the AM supplemented steers ( 0.82 vs. $0.62 \mathrm{~kg} / \mathrm{d}$ ). The greater ADG for PM supplemented steers compared to AM supplemented steers may have been due to higher digestible energy intake ( 8.4 vs. 7.7 Mcal/100 kg BW). In our study, ADG of calves was not influenced $(P>.10)$ by sward height and supplement feeding time probably because performance was buffered by milk. However, the sensitivity of weight change measurements was limited by the length of the experimental period in this study. This probably explains the lack of response to treatments observed with calves. Further 
research is needed to quantify the animal response (ADG) with experiments designed to last longer than $15 \mathrm{~d}$. 


\section{CHAPTER 6: SUMMARY AND CONCLUSION}

Results of this study suggest that cows allowed limited access $(12 \mathrm{~h} / \mathrm{d})$ to pasture consumed greater amounts of forage DM when supplemented in the AM as opposed to PM. Similarly, cows supplemented in the AM consumed a greater amount of forage digestible DM compared to cows fed in the PM. Cows on an unlimited grazing regimen consumed a greater amount of forage DM as well as digestible DM when supplemented in the PM. Increased forage DMI and digestibility resulted in greater intake of forage digestible DM, thus, additional substrates supplied by the supplement probably had less inhibitive effects on ruminal fermentation of fiber. When forage or grazing time is limiting, supplementing in the AM, as opposed to PM, may result in greater forage utilization because of compensatory intake of forage DM and digestible DM. However, when forage or grazing time is not limiting, supplementing in the PM, as opposed to AM, may result in greater pasture utilization because of greater forage digestibility. 


\section{CHAPTER 7: LITERATURE CITED}

Abdul-Razzaq, H. A., and R. Bickerstaffe. 1989. The influence of rumen volatile fatty acids on protein metabolism in growing lambs. Br. J. Nutr. 89:297310

Adams, D. C. 1985. Effect of time of supplementation on performance, forage intake and grazing behavior of yearling beef steers grazing Russian wild ryegrass in the fall. J. Anim. Sci. 61:1037-1042

Akin, D. E. 1982. Microbial breakdown of feed in the digestive tract. In: J. B. Hacker (ed.) Nutritional Limits to Animal Production from Pastures. Commonwealth Agricutlural Bureaux, Slough, UK, pp. 201-223

Akin, D. E. 1986. Interaction of ruminal bacteria and fungi with southern forages. J. Anim. Sci. 63:962-967

Akin, D. E. 1989. Histological and physical factors affecting digestibility of forages. Agron. J. 81:17-25

Aldrich, J. M., L. D. Muller, G. A. Varga, and L. C. Griel. 1993. Nonstructural carbohydrate and protein effects on rumen fermentation, nutrient flow, and performance of dairy cows. J. Dairy Sci. 76:1091-1105

Allen, M. S. 1996. Physical constraints on voluntary intake of forages by ruminants. J. Anim. Sci. 74:3063-3075

Anderson, S. J., J. K. Merrill, and T. J. Klopfenstein. 1988. Soybean hulls as an energy supplement for the grazing ruminant. J. Anim. Sci. 66:2959-2964

AOAC. 1990. Official Methods of Analysis. $15^{\text {th }}$ ed. Assoc. Offic. Anal. Chem., Arlington, VA

Armentano, L.E., T. A. Herrington, C. E. Polan, A. J. Moe, J. H. Herbein, and P. Umstadt. 1986. Ruminal degradation of dried brewers grains, wet brewers grains, and soybean meal. J. Dairy Sci. 69:2124-2133

Baker, R. D., Y. L. P. Le Du and F. Alvarez. 1981. The herbage intake and performance of set-stocked suckler cows and calves. Grass and Forage Sci. 36:201-210.

Baker, M. J., E. C. Prigge and W. B. Bryan. 1988. Herbage Production from Hay fields Grazed by Cattle in Fall and Spring. J. Prod. Agric. 31:275-279 
Bargo, F., D. H. Rearte, F. J. Santini, and L. D. Muller. 2001. Ruminal digestion by dairy cows grazing winter oats pasture supplemented with different levels and sources of protein. J. Dairy Sci. 84:2260-2272

Barthram, G. T. 1986. Experimental techniques: The HFRO sward stick. Biennial Report, Hill Framing Research Organization, 1984/85, pp. 29-30

Barton, R. K., L. J. Krysl, M. B. Judkins. D. W. Holcombe, J. T. Broesder, S. A. Gunter, and S. W. Beam. 1992. Time of daily supplementation for steers grazing dormant intermediate wheatgrass pasture. J. Anim. Sci. 70:547558

Beever, D. E., M. S. Dhanoa, H. R. Losada, R. T. Evans, S. B. Cammell, and J. France. 1986a. The effect of forage species and stage of harvest on the process of digestion occurring in the rumen of cattle. Br. J. Nutr. 56:439454

Beever, D. E., H. R. Losada, S. B. Cammell, R. T. Evans, and M.J. Haines. 1986b. Effect of forage species and season on nutrient digestion and supply in grazing cattle. Br. J. Nutr. 56:209-225

Beever, D. E., and R. C. Siddons. 1986. Digestion and metabolism in the grazing ruminant. In: L. P. Milligan, W. L. Grovum, and A. Dobson (ed.) Control of Digestion and Metabolism in Ruminants. Prentice-Hall, Englewood Cliffs, New Jersey, pp. 479-497

Belesky, D. P and J. M. Fedders. 1994. Defoliation effects on seasonal production and growth rate of cool-season grasses. Agron. J. 86:38-45

Berzaghi, P., J. H. Herbein, and C. E. Polan. 1996. Intake, site, and extent of nutrient digestion of lactating cows grazing pasture. J. Dairy Sci. 79:1581-1589

Blanchard, T., J. Ferguson, L. Love, T. Takeda, B. Henderson, J. Hasler, and W. Chalupa. 1990. Effect of dietary crude-protein type on fertilization and embryo quality of dairy cattle. Am. J. Vet. Res. 51:905-908

Blaser, R. E., H. T. Bryant, R. C. Hammes, Jr., R. L. Boman, J. P. Fontenot, and C. E. Polan. 1969. Managing forages for animal production. Virginia Poly. Inst., Bulletin No. 45, pp. 29-86 
Blaser, R. E., R. C. Hammes, Jr., J. P. Fontenot, H. T. Bryant, C. E. Polan et al. 1986. Growth stages of plants, forage quality and animal production. In: M. C. Holliman (ed.) Forage-Animal Management Systems. Virginia Agric. Exp. Sta. Bull. 86-7, pp. 9

Bodine, T. N., H. T. Purvis, II, C. J. Ackerman, and C. L. Goad. 2000. Effects of supplementing prairie hay with corn and soybean meal on intake, digestion, and ruminal measurements by beef steers. J. Anim. Sci. 78:3144-3154

Bodine, T. N., H. T. Purvis, II, and D. L. Lalman. 2001. Effects of supplement type on animal performance, forage intake, digestion, and ruminal measurements of growing beef cattle. J. Anim. Sci. 79:1041-1051

Brake, A. C., A. L. Goetsch, L. A. Forster, Jr., and K. M. Landis. 1989. Feed intake, digestion and digesta characteristics of cattle fed bermudagrass or orchardgrass alone or with ground barley or corn. J. Anim. Sci. 67:34253436

Bransby, D. I., A. G. Matches, and G. F. Krause. 1977. Disk meter for rapid estimation of herbage yield in grazing trials. Agron. J. 69:393-396

Briseño de la Hoz, V. M., and D. Wilman. 1981. Effects of cattle grazing, sheep grazing, cutting and sward height on a grass-white clover sward. J. Agric. Sci. 97:699-706

Brokow, L., B. W. Hess, and D. C. Rule. 2001. Supplemental soybean oil or corn for beef heifers grazing summer pasture: Effects on forage intake, ruminal fermentation, and site and extent of digestion. J. Anim. Sci. 79:27042712

Bryan, W. B and T. A. Mills. 1988. Seasonality of pasture growth in West Virginia. Proc. $12^{\text {th }}$ Gen. Meeting European Grassland Fed, 4-7 July 1988, Dublin, Ireland, pp. 382-386

Bryan, W. B., W. V. Thayne, and E. C. Prigge. 1990. Sward height and capacitance probe for estimating herbage mass. J. Agron. Crop Sci. $164: 208-212$

Bryan, W. B., E. C. Prigge, M. Lasat, T. Pasha, D. J. Flaherty, and J. Lozier. 2000. Productivity of Kentucky bluegrass pasture grazed at three heights and two intensities. Agronomy, J. 42:30-35 
Bullock, J. M. 1996. Plant competition and population dynamics. In: J. Hodgson and A. W. Illius (ed.) The Ecology and Management of Grazing Systems. CAB International, Wallingford, Oxon, UK. Pp. 69-100

Burns, J. C. 1981. Integration of grazing with other feed resources. In: J. B. Hacker (ed.) Nutritional Limits to Animal Production from Pastures. Proc. Intl. Symp. St. Lucia, Queensland, Australia. Commonwealth Agric. Bureaux, Slough, UK, pp. 455

Burns, J. C., K. R. Pond, D. S. Fischer, and J. M. Luginbuhl. 1997. Changes in forage quality, ingestive mastication, and digesta kinetics resulting from switchgrass maturity. J. Anim. Sci. 75:1368-1379

Buxton, D. R., and M. R. Brasche. 1991. Digestibility of structural carbohydrates in cool-season grass and legume forages. Crop Sci. 31:1338-1345

Buxton, D. R., D. R. Mertens, and K. J. Moore. 1995. Forage quality for ruminants: plant and animal considerations. Prof. Anim. Sci. 11:121-131

Buxton, D. R. 1996. Quality-related characteristics of forages as influenced by plant environment and agronomic factors. Anim. Feed Sci. Technol. 59:37-49

Campling, R. C. 1970. Physical regulation of voluntary intake. In: A. T. Phillipson (ed.) Physiology of Digestion and Metabolism in the Ruminant. Oriel Press, Ltd, Newcastle, UK, pp. 226-234

Canfield, R. W., C. J. Sniffen, and W. R. Butler. 1990. Effects of excess degradable protein on postpartum reproduction and energy balance in dairy cattle. J. Dairy Sci. 73:2342-2349

Carroll, D. J., B. A. Barton, G. W. Anderson, and R. D. Smith. 1988. Influence of protein intake and feeding strategy on reproductive performance of dairy cows. J. Dairy Sci. 71:3476-3481

Casper, D. P., and D. J. Shingoethe. 1989. Lactational responses of early lactation dairy cows to diets varying in ruminal solubilities of carbohydrate and crude protein. J. Dairy Sci. 72:928-941

Casper, D. P., D. J. Shingoethe, and W. A. Eisenbeisz. 1990. Response of early lactation dairy cows fed diets varying in source of nonstructural carbohydrate and crude protein. J. Dairy Sci. 73:1039-1050 
Casper, D. P., H. A. Maiga, M. J. Brouk, and D. J. Schingoethe. 1999. Synchronization of carbohydrate and protein sources on fermentation and passage rates in dairy cows. J. Dairy Sci. 82:1779-1790

Chacon, E. A., T. H. Stobbs, and M. B. Dale. 1978. Influence of sward characteristics on grazing behavior and growth of Hereford steers grazing tropical grass pasture. Aust. J. Agr. Res. 29:89-102

Chan, S. C., J. T. Huber, C. B. Theurer, Z. Wu, K. H. Chen, and J. M. Simas. 1997. Effects of supplemental fat and protein sources on ruminal fermentation and nutrient flow to the duodenum in dairy cows. J. Dairy Sci. 80:152-159

Cherney, D. J. R., J. H. Cherney, and R. F. Lucey. 1993. In vitro digestion kinetics and quality of perennial grasses as influenced by forage maturity. J. Dairy Sci. 76:790-797

Clark, J. H., T. H. Klusmeyer, and M. A. Cameron. 1992. Microbial protein synthesis and flows of nitrogen fractions to the duodenum of dairy cows. J. Dairy Sci. 75:2304-2323

Coleman, S. W., F. M. Pate and D. W. Beardsley. 1976. Effects of level of supplemental energy fed grazing steers on performance during the pasture and subsequent dry lot period. J. Anim. Sci. 42:27-35

Combellas, J., and J. Hodgson. 1979. Herbage intake and milk production by grazing dairy cows. I. The effects of variation in herbage mass and daily herbage allowance in a short-term trial. Grass and Forage Sci. 34:209214

Cone, J. W., W. Cline-Theil, A. Malestein, and A. th van't Klooster. 1989. Degradation of starch by incubation with rumen fluid. A comparison of different starch sources. J. Sci. Food Agric. 49:173-183

Connell, W. E., S. S. Wheeler, and R. C. Tom. 1948. The effect of winter supplementation on subsequent gains of beef steers on grass and in the fattening lot. J. Anim. Sci. 7:430-433

Davies, A. 1977. Structure of the grass sward. Proc. Intl. Meeting Anim. Prod. from Temperate Grassland, Dublin, pp. 36-44 
Dealby, L., J. L. Peyrand, and R. Delagarde. 2001. Effect of the level of concentrate supplementation, herbage allowance and milk yield at turnout on the performance of dairy cows in mid lactation at grazing. Anim. Sci. 73:171-181

DelCurto, T. R., R. C. Cochran, L. R. Corah, A. A. Beharka, E. S. Vanzant, and D. E. Jordan. 1990. Supplementation of dormant tallgrass-prairie forage: II. Performance and forage utilization characteristics in grazing beef receiving supplements of different concentrations. J. Anim. Sci. 68:532-542

Delpozo, M., I. A. Wright, and T. K. Whyte. 1997. Diet selection by sheep and goats and sward composition changes in a ryegrass/white clover sward previously grazed by cattle, sheep or goats. Grass and Forage Sci. $52: 278-290$

Demment, M. W., and P. J. Van Soest. 1985. A nutritional explanation for bodysize patterns of ruminant and non-ruminant herbivores. Am. Nat. 125:641-672

Denham, A. H. 1977. Influence of energy supplements on grazing and feedlot performance of steers. J. Anim. Sci. 45:1-7

Donaldson, R. S., M. A. McCann, H. E. Amos, and C. S. Hoveland. 1991. Protein and fiber digestion by steers grazing winter annuals and supplemented with ruminal escape protein. J. Anim. Sci. 69:3067-3071

Dove, H. 1996. The ruminant, the rumen and the pasture resource: Nutrient interactions in the grazing animal. In: Hodgson, J. and A. W. Illius (ed.). The Ecology and Management of Grazing Systems. CAB Intl., Wallingford, Oxon, UK, pp. 219-246

Drouillard, J. S., and G. L. Kuhl. 1999. Effects of previous nutrition and management on feedlot performance of cattle. J. Anim. Sci. 77 (supp 2): 136-146

Duby, R. T., and J. P. Trischler, II. 1986. Effect of dietary protein on reproduction in the ewe and dairy cow. New England Dairy Feed Conf., Concord, $\mathrm{NH}$

Elizalde, J. C., J. D. Cremin, Jr., D. B Faulkner, and N. R. Merchen. 1998. Performance and digestion by steers grazing tall fescue and supplemented with energy and protein. J. Anim. Sci. 76:1691-1701 
Elizalde, J. C., N. R. Merchen, and D. B. Faulkner. 1999. In situ dry matter and crude protein degradation of fresh forages during the spring growth. J. Dairy Sci. 82:1978-1990

El-Shazly, K., B. A. Dehority, and R. R. Johnson. 1961. Effect of starch on the digestion of cellulose in vitro and in vivo by rumen micro-organisms. J. Anim. Sci. 20:268-273

Feng, P., C. W. Hunt, G. T. Pritchard, and S. M. Parish. 1995. Effect of barley variety and dietary barley content on digestive function in beef steers fed grass hay-based diets. J. Anim. Sci. 73:3476-3484

Ferguson, J. D., D. T. Galligan, T. Blanchard, and M. Reeves. 1993. Serum urea nitrogen and conception rate: The usefulness of test information. J. Dairy Sci. 76:3742-3746

Forbes, T. D. A., and S. W. Coleman. 1987. Herbage intake and ingestive behavior of grazing cattle as influenced by variation in sward characteristics. In: F. W. Horn, J. Hodgson, J. J. Mott and R. R. Brougham (ed.), Proc. Special Session Grazing-land Res., Plant-Animal Interface. Winrock Intl., Morrilton, Arkansas, pp. 141-152

Forbes, T. D. A. 1988. Researching the plant-animal interface: the investigation of ingestive behavior in grazing animals. J. Anim. Sci. 66:2369-2379

Forbes, J. M. 1995. Voluntary Food Intake and Diet Selection in Farm Animals. CAB Intl., Wallingford, UK

Forster, L. A; Jr., A. L. Goetsch, D. L. Galloway, Sr., and Z. B. Johnson. 1993. Feed intake, digestibility, and live weight gain by cattle consuming forage supplemented with rice bran and (or) corn. J. Anim. Sci. 71:3105-3114

Frame, J. and I. A. Dickson. 1985. The digestibility of rotationally grazed perennial ryegrass swards. In: J. Frame (ed.) Grazing. Occasional Symp. No. 19 British Grassl. Soc., pp 206-209

Freer, M. and D. B. Jones. 1985. Feeding values of subterranean clover, lucerne, phalaris and wimmera ryegrass for lambs. Austr J Exp Agr Anim Husb. 24:156-164

Fukushima, R. S., B. A. Dehority, and S. C. Loerch. 1991. Modification of a colorimetric analysis for lignin and its use in studying the inhibitory effects of lignin on forage digestion by ruminal microorganisms. J. Anim. Sci. 69:295-304 
Funk, M. A., M. L. Galyean, M. E. Branine, and L. J. Krysl. 1987. Steers grazing blue grama rangeland throughout the growing season. I. Dietary composition, intake, digesta kinetics and ruminal fermentation. J. Anim. Sci. 65:1342-1353

Galyean, M. L., and F. N. Owens. 1991. Effect of diet composition and level of feed intake on site and extent of digestion in ruminants. In: T. Tsuda, Y. Ssaki, and R. Kawashima (ed.) Physiological Aspects of Digestion and Metabolism in Ruminants. Academic Press, New York, pp. 483

Galyean, M. L., and A. L. Goetsh. 1993. Utilization of forage fiber by ruminants. In: H. G. Jung, D. R. Buxton, R. D. Hatfield, and J. Ralph (ed.). Forage Cell Wall Structure and Digestibility. ASA-CSSA-SSSA, 677 S. Segoe Rd., Madison, Wisconsin, pp. 33-71

Garrett, J. E., R. D. Goodrich, J. C. Meiske, and M. D. Stern. 1987. Influence of supplemental nitrogen source on digestion of nitrogen, dry matter and organic matter and on in vivo rate of ruminal protein degradation. J. Anim. Sci. 64:1801-1812

Gekara, O. J., E. C. Prigge, W. B. Bryan, M. Schettini, E. L. Nestor, and E. C. Townsend. 2001. Influence of pasture sward height and concentrate supplementation on intake, digestibility, and grazing time of lactating beef cows. J. Anim. Sci. 79:745-752

Gibb, M. J., R. D. Rainer, and A. M. E. Sayer. 1989. The impact of grazing severity on perennial ryegrass/white clover swards stocked continuously with beef cattle. Grass and Forage Sci. 44:315-328

Goering, H. K., and P. J. Van Soest. 1970. Forage Fiber Analysis (Apparatus, Reagents, Procedures and Some Applications). Agric. Handbook No. 379. ARS-USDA, Washington, DC

Greenhalgh, J. F. D., G. W. Reid, J. N. Aitken and E. Florence. 1966a. The effect of grazing intensity on herbage consumption and animal production. I. Short-term effects in strip-grazed dairy cows. J. Agric. Sci. Camb. 67:1323

Greenhalgh, J. F. D., G. W. Reid and J. N. Aitken. 1966b. The effect of grazing intensity on herbage consumption and animal production. II. Longer-term effects in strip-grazed dairy cows. J. Agric. Sci. Camb. 69:217-223 
Hacker, J. B., and D. J. Minson. 1981. The digestibility of plant parts. Herb. Abstr. 51:460-482

Hamilton, B. A., J. R. Ashes, and W. Carmichael. 1992. Effect of formaldehyde treated sunflower meal on milk production of grazing dairy cows. Aust. J. Agric. Res. 43:379-387

Hanna, W. W., W. G. Monson, and G. W. Burton. 1973. Histological examination of fresh forage leaves after in vitro digestion. Crop Sci. 13:98-102

Harris, W. 1978. Defoliation as a determinant of the growth, persistence, and composition of pasture. In: J. R. Wilson (ed.) Plant Relations in Pastures. CSIRO, Canberra, Australia, pp. 67-85

Hart, R. H. 1991. Developing strategies for integrating forage parameters to meet the nutritional needs of grazing livestock. Proc. $2^{\text {nd }}$ Grazing Livest. Nutr. Conf. Okla. Agric. Exp. Stn. Misc. Publ. 133:64-69

Hatfield, R. D. 1989. Structural polysaccharides in forages and their degradability. Agron. J. 81:39-46

Heldt, J. S., R. C. Cochran, C. P. Mathis, B. C. Woods, K. C. Olson, E. C. Titgemeyer, et al. 1999. Effects of level and source of carbohydrate and level of degradable intake protein on intake and digestion of low-quality tallgrass-prairie hay by beef steers. J. Anim. Sci. 77:2846-2854

Henning, P. H., D. G. Steyn, and H. H. Meissner. 1993. Effect of synchronization of energy and nitrogen supply on ruminal characteristics and microbial growth. J. Anim. Sci. 71:2516-2528

Henricksen, R., and D. J. Minson. 1980. The feed intake and grazing behavior of cattle grazing a crop of Lablab purpureus cv. Rongai. J. Agr. Sci. 95:547-554

Herrera-Saldana, R., and J. T. Huber. 1989. Influence of varying protein and starch degradabilities on performance of lactating cows. J. Dairy Sci. 72:1477-1483

Herrera-Saldana, R., R. Gomez-Alarcon, M. Torabi, and J. T. Huber. 1990a. Influence of synchronizing protein and starch degradation in the rumen on nutrient utilization and microbial protein synthesis. J. Dairy Sci. 73:142148 
Herrera-Saldana, R., J. T. Huber, and M. H. Poore. 1990b. Dry matter, crude protein and starch degradability of five cereal grains. J. Dairy Sci. 73:2386-2393

Hess, R. W., L. J. Krysl, M. B. Judkins, D. W. Holcombe, J. D. Hess, D. R. Hanks, and S. A. Huber. 1996. Supplemental cracked corn or wheat bran for steers grazing endophyte-free fescue pasture: effects on live weight gain, nutrient quality, forage intake, particulate and fluid kinetics, ruminal fermentation, and digestion. J. Anim. Sci. 74:1116-1125

Hoden, A., J. L. Peyrand, A. Muller, L. Delaby, and P. Faverdin. 1991. Simplified rotational grazing management of dairy cows: effects of rates of stocking and concentrate. J. Agric. Sci. 116:417-428

Hodgson, J. 1975. The influence of grazing pressure and stocking rate on herbage intake and animal performance. In: Hodgson, J. and Jackson, D. K. (ed.). Pasture utilization by the Grazing Animal. Occasional Symp. British Grassl. Soc., No. 8, pp. 93-103

Hodgson, J. 1981. Variations in the surface characteristics of the sward and short-term rate of herbage intake by calves and lambs. Grass and Forage Sci. 36:49-57

Hodgson, J. 1984. Sward conditions, herbage allowance and animal production: an evaluation of research results. Proc. New Zealand Soc. Anim. Prod. 44:99-104

Hodgson, J. 1990. Grazing Management: science into practice. Longman group UK.

Hodgson, J. and A. W. Illius. 1996. The Ecology and Management of Grazing Systems. CAB Intl., Wallingford, Oxon, UK, pp. 165-195

Holden, L. A., L. D. Muller, T. Lykos, and T. W. Cassidy. 1995. Effect of corn silage supplementation on intake and milk production in cows grazing grass pasture. J. Dairy Sci. 78:154-160

Holden, L. A., L. D. Muller, and S. L. Fales. 1994. Estimation of intake in high producing Holstein cows grazing grass pasture. J. Dairy Sci. 77:23322340

Holt, D. A., and A. R. Hilst. 1969. Daily variation in carbohydrate content of selected forage crops. Agron. J. 61:239-242 
Hongerholt, D. D., and L. D. Muller. 1998. Supplementation of rumen undegradable protein to the diets of early lactation Holstein cows on grass pasture. J. Dairy Sci. 81:2204-2214

Hoover, W. H. 1986. Chemical factors involved in ruminant fiber digestion. J. Dairy Sci. 69:2755-2766

Hoover, W. H., and S. R. Stokes. 1991. Balancing carbohydrates and protein for optimum rumen microbial yield. J. Dairy Sci. 74:3630-3644

Horn, G. W., and F. T. McCollum. 1987. Energy supplementation of grazing ruminants. In: Proc. of the Grazing Livestock Nutr. Conf., Univ. of Wyoming, Leramie, pp. 125-136

Horn, G. W., M. D. Cravey, F. T. McCollum, C. A. Strasia, E. G. Krenzer, Jr., and P. L. Claypool. 1995. Influence of high-starch vs high-fiber energy supplements on performance of stocker cattle grazing wheat pasture and subsequent feedlot performance. J. Anim. Sci. 73:45-54

Hungate, R. E. 1966. The rumen and its microbes. Academic Press, New York

Hunt, L. A. 1965. Some implications of death and decay in pasture production. J. Br. Grassl. Soc. 20:27-31

Hunt, C. W., J. F. Parkinson, R. A. Roeder, and D. G. Falk. 1989. The delivery of cottonseed meal at three different time intervals to steers fed low-quality grass hay: Effects on digestion and performance. J. Anim. Sci. 67:13601366

Jameison, W. S and J. Hodgson. 1979a. The effect of daily herbage allowance and sward characteristics upon the ingestive behavior and herbage intake of calves under strip-grazing management. Grass and Forage Sci. 34:261-271

Jameison, W. S and J. Hodgson. 1979b. The effect of variation in sward characteristics upon ingestive behavior and herbage intake of calves and lambs under a continuous stocking management. Grass and Forage Sci. 34:273-282

Jennings, P. G., and W. Holmes. 1984. Supplementary feeding of dairy cows on continuously stocked pasture. J. Agric. Sci. 103:161-170

Johnson, R. R. 1976. Influence of carbohydrate solubility on non-protein nitrogen utilization in the ruminant. J. Anim. Sci. 43:184-191 
Johnson, J. A., J. S. Caton, W. Poland. D. R. Kirby, and D. V. Dhuyvetter. 1998. Influence of season on dietary composition, intake, and digestion by beef steers grazing mixed-grass prairie in the Northern Great Plains. J. Anim. Sci. 76:1682-1690

Jones, C. A. 1985. C 4 grasses and cereals. John Wiley \& Sons, New York

Jones-Endsley, J. M., M. J. Cecava, and T. R. Johnson. 1997. Effects of dietary supplementation on nutrient digestion and the milk yield of intensively grazed lactating dairy cows. J. Dairy Sci. 80:3283-3292

Jordan, E. R., and L. V. Swanson. 1979. Serum progesterone and luteinizing hormone in dairy cattle fed varying levels of crude protein. J. Anim. Sci. 48:1154-1158

Jordon, D. J., T. J. Klopfenstein, and D. C. Adams. 2002. Dried poultry waste for cows grazing low-quality winter forage. J. Anim. Sci. 80:818-824

Judkins, M. B., L. J. Krysl, R. K. Barton, D. W. Holcombe, S. A. Gunter, and J. T. Broesder. 1991. Effects of cottonseed meal supplementation time on ruminal fermentation and forage intake by Holstein steers fed fescue hay. J. Anim. Sci. 69:3789-3797

Jung, H. G. 1989. Forage lignins and their effects on fiber digestibility. Agron. J. $81: 33-38$

Karges, K. K., T. J. Klopfenstein, V. A. Wilkerson, and D. C. Clanton. 1992. Effects of ruminally degradable and escape protein supplements on steers grazing summer native range. J. Anim. Sci. 70:1957-1964

Kellaway, R., and S. Porta. 1993. Feed concentrate supplements for dairy cows. Dairy Research and Development Corp., Victoria, Australia

Kennedy, P. M. 1990. Constraints to rumen dynamics on lignocellulose digestion. In: Akin D. E., L. G. Ljungdahl, J. R. Wilson, and P. R. Harris (ed.), Microbial and Plant Opportunities to Improve Lignocellulose Utilization by Ruminants. Elsevier, New York, pp. 3-15

Khorasani, G. R., G. De Boer, B. Robinson, and J. J. Kennelly. 1994. Influence of dietary protein and starch on production and metabolic responses of dairy cows. J. Dairy Sci. 77:813-824

Kolver, E., L. D. Muller, G. A. Varga, and T. W. Cassidy. 1998. Synchronization of ruminal degradation of supplemental carbohydrates with pasture nitrogen in lactating dairy cows. J. Dairy Sci. 81:2017-2028 
Krysl, L. J., and B. W. Hess. 1993. Influence of supplementation on behavior of grazing cattle. J. Anim. Sci. 71:2546-2555

Leaver, J. D., R. C. Campling, and W. Holmes. 1968. Use of supplementary feeds for grazing dairy cows. Dairy Sci. 355-361 (Abstr.)

Leaver, J. D. 1986. Effects of supplements on herbage intake and performance. In: J. Frame (ed.) Grazing. Occassional Symp. No. 19 British Grassl. Soc., pp. $79-88$

Lechtenberg, V. L., D. A. Holt, and H. W. Youngberg. 1971. Diurnal variation in nonstructural carbohydrate, in vitro digestibility, and leaf to stem ratio of alfalfa. Agron. J. 63:719-724

Le Du, Y. L. P., R. D. Baker and R. D. Newberry. 1979. Supplementary feed in the diet of dairy cows offered fresh herbage. Anim. Prod. 28:413

Leonard, E. S., K. R. Pond, R. W. Harvey, and R. G. Crickenberger. 1989. Effects of corn grinding and time of corn feeding on growth, starch utilization and digesta passage characteristics of growing steers fed hay-based diets. J. Anim. Sci. 67:1603-1611

Mabjeesh, S. J., A. Arieli, I. Bruckental, S. Zamwell, and H. Tagari. 1996. Effects of type of protein supplementation on duodenal amino acid flow and absorption in lactating dairy cows. J. Dairy Sci. 79:1792-1801

Marshall, S. A., C. P. Campbell, and J. G. Buchanan-Smith. 1998. Herbage biomass and intake of beef cows with calves grazing a grass-legume pasture in Southern Ontario. Can. J. Anim. Sci. 78:211-218

Marston, T. T., and K. S. Lusby. 1995. Effects of energy or protein supplements and stage of production on intake and digestibility of hay by beef cows. J. Anim. Sci. 73:651-656

Marston, T. T., K. S. Lusby, R. P. Wettermann, and H. T. Purvis. 1995. Effects of feeding energy or protein supplement before or after calving on performance of spring-calving cows grazing native range. J. Anim. Sci. 73:657-664

Martz, F. A., J. Gerrish, R. Belyea, and V. Tate. 1999. Nutrient content, dry matter yield, and species composition of cool-season pasture with management-intensive grazing. J. Dairy Sci. 82:1538-1544 
Mayland, H. F., G. E. Shewmaker, J. C. Burns, and D. S. Fisher. 1998. Morning and evening harvest effects on animal performance. In: Proc California/Nevada Alfalfa Symp., Reno, Nevada. December 1998, pp. 2630

Mayne, C. S., R. D. Newberry, S C. F. Woodcock, and R. J. Wilkins. 1987. Effect of grazing severity on grass utilization and milk production of rotationally grazed dairy cows. Grass and Forage Sci. 42:59-72

McCollum, F. T., and M. L. Galyean. 1985. Influence of cottonseed meal supplementation on voluntary intake, rumen fermentation and rate of passage of prairie hay in beef steers. J. Anim. Sci. 60:570-577

McCormick, J. D. Ward, D. D. Redfearn, D. D. French, D. C. Blouin, A. M. Chapa, and J. M. Fernandez. 2001. Supplemental dietary protein for grazing dairy cows: effect on pasture intake and lactation performance. J. Dairy Sci. 84:896-907

McCracken, B. A., M. B. Judkins, L. J. Krysl, D. W. Holcombe, and K. K. Park. 1993. Supplemental methionine and time of supplementation effects on ruminal fermentation, digesta kinetics, and in situ dry matter and neutral detergent fiber disappearance in cattle. J. Anim. Sci. 71:1932-1939

Meijs, J. A. C., and J. A. Hoekstra. 1984. Concentrate supplementation of grazing dairy cows. I. Effects of concentrate intake and herbage allowance on herbage intake. Grass and Forage Sci. 39:59-66

Mertens, D. R., and J. R. Loften. 1980. The effect of starch on forage fiber digestion kinetics in vitro. J. Dairy Sci. 63:1427-1446

Milne, J. A., J. Hodgson, R. Thompson, W. G. Souter, and G. T. Barthram. 1982. The diet ingested by sheep grazing sward differing in white clover and perennial ryegrass content. Grass and Forage Sci. 37:209-218

Minson, D. J., and M. N. McLeod. 1970. The digestibility of temperate and tropical grasses. Proc. Intl. Grassl. Congr., Surfers Paradise, Queensland, pp. 719-722

Minson, D. J. 1971. The digestibility and voluntary intake of six varieties of panicum. Austr. J. Exp. Agric. Anim. Husb. 11:18-25

Minson, D. J., and J. R. Wilson. 1980. Comparative digestibility of tropical and temperate forage - a contrast between grasses and legumes. J. Aus. Inst. Agric. Sci. 46:247-249 
Minson, D. J. 1982. Effects of chemical and physical composition of herbage upon intake. In: J. B. Hacker (ed.) Nutritional Limits to Animal Production from Pastures. Commonwealth Agri. Bureaux, Farnham Royal, U. K, pp. 167-182

Minson, D. J. 1990. Forage in Ruminant Nutrition. Academic Press Inc., San Diego, California

Moore, J. E., M. H. Brant, W. E. Kunkle, and D. I. Hopkins. 1999. Effects of supplementation on voluntary forage intake, diet digestibility, and animal performance. J. Anim. Sci. 77 (supp 2): 122-135

Moseley, G., and J. R. Jones. 1979. Some factors associated with the difference in nutritive value of artificially dried red clover and perennial ryegrass for sheep. Br. J. Nutr. 42:139-147

Moseley, G., and J. R. Jones. 1984. The physical digestion of perennial ryegrass (L. perenne) and white clover ( T. repens) in the foregut of sheep. Br. J. Nutr. 52:381-390

Moseley, G., and D. W. Dellow. 1985. Particle breakdown and chewing activity in sheep fed on fresh perennial ryegrass and white clover. Proc. Nutr. Soc. 44:52A (Abstr.)

Mould, F. L., and E. R. Ørskov. 1984. Manipulation of rumen fluid $\mathrm{pH}$ and its influence on cellulolysis in sacco, dry matter degradation and the rumen microflora of sheep offered either hay or concentrate. Anim. Feed Sci. Technol. 10:1-15

Murphy, B. 1990. Pasture Management. In: C. A. Francis, C. B. Flora, and L. D. King (ed.) Sustainable Agriculture in Temperate Zones. John Wiley and Sons, Inc., New York, pp. 231-261

National Research Council. 1984. Nutrient Requirements of Beef Cattle

National Research Council. 1989. Nutrient Requirements of Dairy Cattle

National Research Council. 2001. Nutrient Requirements of Dairy Cattle

Nocek, J. E., and J. B. Russell. 1988. Protein and energy as an integrated system: relationship of ruminal protein and carbohydrate availability to microbial synthesis and milk production. J. Dairy Sci. 71:2070-2107 
Nocek, J. E., and S. Tamminga. 1991. Site of digestion of starch in the gastrointestinal tract of dairy cows and its effect on milk yield and composition. J. Dairy Sci. 74:3598-3629

Nordin, M., and R. C. Campling. 1976. Digestibility studies with cows given whole and rolled cereal grains. Anim. Prod. 23:305-315

Orr, R. J., P. D. Penning, A. Harvey, and R. A. Chapman. 1997. Diurnal patterns of intake rate by sheep grazing monocultures of ryegrass or white clover. Appl Anim Behav Sci. 52:65-77

Ørskov, E. R., and C. Fraser. 1975. The effects of processing of barley based supplements on rumen $\mathrm{pH}$, rate of digestion and voluntary intake in sheep. Br. J. Nutr. 34:493-500

Ørskov, E. R. 1986. Starch digestion and utilization in ruminants. J. Anim. Sci. 63:1624-1633

Park, K. K., L. J. Krysl, B. A. McCracken, M. B. Judkins, and D. W. Holcombe. 1994. Steers grazing intermediate wheatgrass at various stages of maturity: Effects on nutrient quality, forage intake, digesta kinetics, ruminal fermentation, and serum hormones and metabolites. J. Agric. Sci. 72:476-486

Pearson, C. J. and R. L. Ison. 1997. Agronomy of Grassland Systems, $2^{\text {nd }}$ edition, Cambridge University Press, pp. 74-95

Penning, P. D., A. J. Parsons, R. J. Orr, and T. T. Treacher. 1991a. Intake and behavior responses by sheep to changes in sward characteristics under continuous stocking. Grass and Forage Sci. 46:15-28

Penning, P. D., A. J. Rook, and R. J. Orr. 1991b. Patterns of ingestive behavior of sheep continuously stocked on monocultures of ryegrass or white clover. Appl. Anim. Behav. Sci. 31:237-250

Penning, P. D., R. H. Johnson, and R. J. Orr. 1996. Effects of continuous stocking with sheep or goats on sward composition and animal production from a grass and white clover pasture. Small Rum. Res. 21:19-29

Perry, T. W., D. A. Huber, G. O. Mott, C. L. Rhykerd, and R. W. Taylor. 1971. Effect of level of pasture supplementation on pasture, dry lot and total performance of beef cattle. J. Anim. Sci. 32:744-748 
Philips, C.J.C. and J. D. Leaver. 1985. Seasonal and diurnal variation in the grazing behavior of dairy cows. In: J. Frame (ed.) Grazing. Occasional Symp No. 19 British Grassl Soc., pp 98-104

Playne, M. J. 1978. Differences between cattle and sheep in their digestion and relative intake of a mature tropical grass hay. Anim. Feed Sci. Technol. 3:41-49

Poppi, D. P., D. J. Minson, and J. H. Ternouth. 1980. Studies of cattle and sheep eating leaf and stem fractions of grasses. I. The voluntary intake, digestibility and retention time in the reticulo-rumen. Aust. J. Agric. Res. 32:99-108

Poppi, D. P., D. J. Minson, and J. H. Ternouth. 1981. Studies of cattle and sheep eating leaf and stem fractions of grasses. III. The retention time in the rumen of large feed particles. Aust. J. Agric. Res. 32:123-137

Poppi, D. P., and S. R. McLennan. 1995. Protein and energy utilization by ruminants at pasture. J. Anim. Sci. 73:278-290

Prigge, E. C., M. J. Baker, and G. A. Varga. 1984. Comparative digestion, rumen fermentation and kinetics of forage diets by steers and wethers. J. Anim. Sci. 59:237-245

Prigge, E. C., W. B. Bryan, and E. L. Nestor. 1997. Sward height on performance of cow-calf units and yearling steers grazing cool season pasture. Proc. $18^{\text {th }}$ Intl. Grassl. Congr., Winnigpeg/Saskatoon, Canada. 29:97-98

Prigge, E. C., W. B. Bryan, and E. S. Goldman-Innis. 1999. Early- and lateseason grazing of orchardgrass and fescue hay fields over seeded with red clover. Agron J. 91:690-696

Rayburn, E. B., and S. B. Rayburn. 1998. A standardized plate meter for estimating mass in on-farm research trials. Agron J. 90:238-241

Redmon, L.A., F. T. McCollum, III, G. W. Horn, M. D. Cravey, P. A. Beck, J. M. Mieres, and R. San-Julian. 1995. Forage intake by beef steers grazing winter wheat with varied herbage allowances. J. Range Manage. 48:198201

Reid, R. L., G. A. Jung, and W. V. Thayne. 1988. Relationships between nutritive quality and fiber components of cool season and warm season forages: A retospective study. J. Anim. Sci. 66:1275-1291 
Reid, R. L., G. A. Jung, J. M. Cox-Ganser, B. F. Rybeck, and E. C. Townsend. 1990. Comparative utilization of warm- and cool-season forages by cattle, sheep and goats. J. Anim. Sci. 68:2986-2994

Reis, R. B., and D. K. Combs. 2000. Effects of increasing levels of grain supplementation on rumen environment and lactation performance of dairy cows grazing grass-legume pasture. J. Dairy Sci. 83:2888-2898

Robertson, J. B and P. J. Van Soest. 1981. The detergent system of analysis and its application to human foods. In: W. P. T. James and O. Theander (Ed.) The Analysis of Dietary Fiber. Marcell Dekker, New York, pp. 123158

Robinson, P. H., S. Tamminga, and A. M. van Vuuren. 1987. Influence of declining level of feed intake and proportion of starch in the concentrate on rumen ingestion quality, composition and kinetics of ingesta turnover in dairy cows. Livest. Prod. Sci. 17:37-62

Robinson, P. H. 1989. Dynamic aspects of feeding management for dairy cows. J. Dairy Sci. 72:1197-1209

Robinson, P. H., and R. E. McQueen. 1994. Influence of supplemental protein source and feeding frequency on rumen fermentation and performance in dairy cows. J. Dairy Sci. 77:1340-1353

Robinson, P. H., M. Gill, and J. J. Kennelly. 1997. Influence of time of feeding a protein meal on ruminal fermentation and fore stomach digestion in dairy cows. J. Dairy Sci. 80:1366-1373

Rook, A. J., C. A. Huckle and P. D. Penning. 1994a. Effects of sward height and concentrate supplementation on ingestive behavior of spring-calving dairy cows grazing grass-clover swards. Appl. Anim. Behav. Sci. 40:101-112

Rook, A. J., C. A. Huckle and R. J. Wilkins. 1994b. The effects of sward height and concentrate supplementation on the performance of spring calving dairy cows grazing perennial ryegrass-white clover sward. Anim. Prod. 58:167-172

Santos, F. A. B., J. T. Huber, R. S. Swingle, J. M. Simas, K. H. Chen, and P. Yu. 1998a. Milk yield and composition of lactating cows fed steam-flaked sorghum and graded levels of ruminally degradable protein. J. Dairy Sci. $81: 215-220$ 
Santos, F. A. B., J. E. P. Santos, C. B. Theurer, and J. T. Huber. 1998b. Effects of rumen undegradable protein on dairy cow performance: A 12-year literature review. J. Dairy Sci. 81:3182-3213

SAS Institute, Inc. 1985. SAS Users' Guide: Statistics (Version 5 ed.). SAS Inst. Inc., Cary, NC

Schingoethe, D. J. 1991. Protein quality and amino acid supplementation in dairy cattle. Proc. South-West Nutr. Manage. Conf., Phoenix, AZ. Dep. Anim. Sci., Univ. of Arizona, Tuscon, Arizona, pp. 101-106

Schor, A., and G. A. Gagliostro. 2001. Undegradable protein supplementation to early-lactation dairy cows in grazing conditions. J. Dairy Sci. 84:15971606

Schwab, C. G. 1994. Optimizing amino acid nutrition for optimum yields of milk and milk ptotein. Proc. South-West Nutr. Manage. Conf., Tempe, AZ. Dep. Anim. Sci., Univ. of Arizona, Tuscon, Arizona, pp. 114-129

Schwinning, S., and A. J. Parsons. 1996. A spatially explicit grazing population model of stoloniferous $\mathrm{N}$-fixing legumes in mixed pasture with grass. J. Ecology 84:815-826

Seath, D. M., and G. D. Miller. 1946. Effects of warm weather on grazing performance of milking cows. J. Dairy Sci. 29:199-206

Shabi, Z., A. Arieli, I. Bruckental, Y. Aharoni, S. Zamwel, A. Bor, and H. Tagari. 1998. Effect of synchronization of the degradation of dietary crude protein and organic matter and feeding frequency on ruminal fermentation and flow of digesta into the abomasum of dairy cows. J. Dairy Sci. 81:1991-2000

Sharma, B. K., R. A. Erdman, and J. B. Reeves, III. 1988. Rate and extent of in situ digestion of medium and high quality alfalfa and orchardgrass neutral detergent fiber as determined by extended periods in incubation time. J. Dairy Sci. 71:3509-3513

Shroeder, G. F., and G. A. Gagliostro. 2000. Fishmeal supplementation to grazing dairy cattle in early lactation. J. Dairy Sci. 83:2899-2906

Siebert, B. D., and P. M. Kennedy. 1972. The utilization of speargrass (Heteropogon contortus L.). I. Factors limiting intake and utilization by cattle and sheep. Aust. J. Agric. Res. 23:35-44 
Sinclair, L. A., P. C. Garnsworthy, J. R. Newbold, and P. J. Buttery. 1993. Effect of synchronizing the rate of dietary energy and nitrogen release on rumen fermentation and microbial protein synthesis in sheep. J. Agric. Sci. (Camb.) 120:251-262

Sinclair, L. A., P. C. Garnsworthy, J. R. Newbold, and P. J. Buttery. 1995. Effects of synchronizing the rate of dietary energy and nitrogen release in diets with a similar carbohydrate composition on rumen fermentation and microbial protein synthesis. J. Agric. Sci. (Camb.) 124:463-472

Sniffen, C. J., and P. H. Robinson. 1987. Microbial growth and flow as influenced by dietary manipulations. J. Dairy Sci. 70:425-441

Song, M. K., and J. J. Kennelly. 1990. Ruminal fermentation pattern, bacterial population and ruminal degradation of feed ingredients as influenced by ruminal ammonia concentration. J. Anim. Sci. 68:1110-1120

Soriano, F. D., C. E. Polan, and C. N. Miller. 2000. Milk production and composition, rumen fermentation parameters and grazing behavior of dairy cows supplemented with different forms and amounts of corn grain. J. Dairy Sci. 83:1520-1529

Stern, M. D., W. H. Hoover, C. J. Sniffen, B. A. Crooker, and P. H. Knowlton. 1978. Effects of nonstructural carbohydrates, urea and soluble protein levels on microbial protein synthesis in continuous culture of rumen contents. J. Anim. Sci. 47:944-956

Stern, M. D., and W. H. Hoover. 1979. Methods for determining and factors affecting rumen microbial synthesis: A review. J. Anim. Sci. 49:15901603

Stern, M. D., L. M. Rode, R. W. Prange, R. H. Stanffacher, and L. D. Satter. 1983. Ruminal protein degradation of corn gluten meal in lactating dairy cattle fitted with duodenal t-type cannulae. J. Anim. Sci. 56:194-205

Stobbs, T. H. 1973. The effect of plant structure on the intake of tropical pastures. I. Variation in the bite size of grazing cattle. Aust. J. Agric. Res. 24:809-819

Stokes, S. R., W. H. Hoover, T. K. Miller, and R. P. Manski. 1991. Impact of carbohydrate and protein levels on bacterial metabolism in continuous culture. J. Dairy Sci. 74:860-870 
Sunvold, G. D., R. C. Cochran, and E. S. Vanzant. 1991. Evaluation of wheat middlings as a supplement for beef cattle consuming dormant bluestemrange forage. J. Anim. Sci. 69:3044-3054

Sunvold, G. D., and R. C. Cochran. 1991. Evaluation of ADL, APL, AIA, and IADF as internal markers for prediction of alfalfa, bromegrass, and prairie hay digestibility by beef steers. J. Anim. Sci. 69:4951-4955

Terry, R. A., and J. M. A. Tilley. 1964. The digestibility of the leaves and stem of perennial ryegrass, cocksfoot, timothy, tall fescue, Lucerne and sainfoin as measured by an in vitro procedure. J. Br. Grassl. Soc. 19:363-372

Thornton, R. F., and D. J. Minson. 1973. The relationship between apparent retention time in the rumen, voluntary intake and apparent digestibility of legume and grass diets in sheep. Aust. J. Agric. Res. 24:889-898

Triplett, B. L., D. A. Neuendorff, and R. D. Randel. 1995. Influence of undegraded intake protein supplementation on milk production, weight gain, and reptoduction performance in postpartum Brahman cows. J. Anim. Sci. 73:3223-3229

Twigg, J. R., and L. G. van Gils. 1998. Practical aspects of feeding protein of dairy cows. In: Z. W. Haresign and D. J. A. Cole (ed.) Recent Developments in Ruminant Nutrition. Buttersworth, London, England, pp. 196-212

Ulyatt, M. J. 1981. The feeding value of temperate pastures. In: F. H. W. Morley (ed.) Grazing Animals. Elsevier North-Holland Inc., 52, Vanderbilt Ave, New York, pp. 125-139

Ulyatt, M. J., G. C. Waghorn, A. John, C. S. W. Reid, and J. Monro. 1984. Effect of intake and feeding on feeding behavior and quantitative aspects of digestion in sheep fed chaffed Lucerne hay. J. Agric. Sci. (Camb.) 102:645-657

Van Soest, P. J., J. B. Robertson, and B. A. Lewis. 1991. Methods for Dietary Fiber, Neutral Detergent Fiber and Non-starch Polysaccharides in relation to Animal Nutrition. J. Dairy Sci. 74:3583-3597

Van Soest, P. J. 1994. Nutritional Ecology of the Ruminant. Cornell Univ. Press, Ithaca, New York, pp. 165-195 
Van Vuuren, A. M., C. J. Van der Koelen, and J. Vroons-de Bruin. 1986. Influence of the level and composition of concentrate supplements on rumen fermentation patterns of grazing dairy cows. Neth. J. Agric. Sci. $34: 457-467$

Van Vuuren, A. M., S. Tamminga, and R. S. Katelaar. 1990. Ruminal availability of nitrogen and carbohydrates from fresh and preserved herbage in dairy cows. Neth. J. Agric. Sci. 38:499-512

Van Vuuren, A. M., S. Tamminga, and R. S. Katelaar. 1991. In sacco degradation of organic matter and crude protein of fresh grass (Lolium perenne) in the rumen of grazing dairy cows. J. Agric. Sci. (Camb.) $116: 429-436$

Vanzant, E. S., R. C. Cochran, K. A. Jacques, A. A. Beharka, T. DelCurto, and T. B. Avery. 1990. Influence of level of supplementation and type of grain in supplements on intake and utilization of harvested, early-seasongrowing, bluestem-range forage by beef steers. J. Anim. Sci. 68:14571468

Vaughan, J. M., J. A. Bertrand, T. C. Jenkins, and B. W. Pinkerton. 2002. Effects of feeding time on nitrogen capture by lactating dairy cows grazing rye pastures. J. Dairy Sci. 85:1267-1272

Virtanen, A. I. 1966. Milk production of cows on protein-free feeds. Science. 153:1603-1608

Voet, D. and J. G. Voet. 1995. Biochemistry. John Wiley \& Sons Inc., One Valley Drive, Somerset, New Jersey, pp. 649-659

Waldo, D. R., G. A. Varga, G. B. Huntington, B. P. Glenn, and H. F. Tyrell. 1990. Energy components of growth in Holstein steers fed formaldehyde- and formic acid-treated alfalfa or orchardgrass silages at equalized intakes of dry matter. J. Anim. Sci. 68:3792-3804

Weston, R. H. 1984. Rumen digesta load in relation to voluntary feed consumption and rumination in roughage-fed young sheep. Can. J. Anim. Sci. 64 (suppl.): 324-325

Weston, R. H., and D. P. Poppi. 1987. Comparative aspects of food intake. In: J. B. Hacker, and J. H. Ternouth (ed.) The Nutrition of Herbivores. Academic Press, New York, pp. 133-162 
Wheeler, J. S., D. L. Lalman, G. W. Horn, L. A. Redmon, and C. A. Lents. 2001. Effects of supplementation on intake, digestion, and performance of beef cattle consuming fertilized, stockpiled bermudagrass forage. J. Anim. Sci. $80: 780-789$

Wiley, J. S., M. K. Petersen, C. K. Clark, R. P. Ansotegui, and D. W. Lodman. 1991. The influence of timing and the addition of urea to supplements containing DL-methionine on ruminal fermentation and cow weight change in beef cows. J. Anim. Sci. 69:4617-4627

Wilkins, R. J., M. J. Gibb, and C. A. Huckle. 1995. Lactation performance of spring-calving dairy cows grazing mixed perennial ryegrass/white clover swards of differing composition and height. Grass and Forage Sci. 50:199-208

Wilkinson, J. M., W. R. Price, S. R. Russell, and P. Jones. 1994. Diurnal variation in dry matter and sugar content of ryegrass. $4^{\text {th }}$ Research Meeting British Grassl Soc., Reading, UK, pp. 61-62

Williams, M. J., and A. C. Hammond. 1999. Rotational vs continuous intensive stocking management of bahiagrass for cows and calves. Agron. J. 91:11-16

Wilman, D., B. M. Ojuderie, and E. O. Asare. 1976. Nitrogen and Italian ryegrass. 3. Growth up to 14 weeks: yields, proportions, digestibilities and nitrogen contents of crop fractions, and tiller populations. J. Br. Grassl. Soc. 31:73-79

Wilson, J. R. 1994. Cell wall characteristics in relation to forage digestion by ruminants. J. Agr. Sci. 122:173-182

Winks, L., A. R. Laing, P. K. O'Rourke and G. S. Wright. 1979. Factors affecting response to urea-molasses supplements by yearling cattle on tropical Queensland. Aust. J. Exp. Agric. Anim. Husb. 19:522-529

Wright, I. A., J. R. Jones, and A. J. Parsons. 2001. Effects of grazing by sheep or cattle on sward structure and subsequent performance of weaned lambs. Grass and Forage Sci. 56:138-150

Wright, I. A., T. K. Whyte and K. Osoro. 1990. The herbage intake and performance of autumn-calving beef cows and their calves when grazing continuously at two sward heights. Anim. Prod. 51:85-92 
Wu, Z., L. J. Massingill, R. P. Walgenbach, and L. D. Satter. 2001. Cracked dry or finely ground high moisture shelled corn as a supplement for grazing cows. J. Dairy Sci. 84:2227-2230

Youngberg, H. W., D. A. Holt, and V. L. Lechtenberg. 1972. Diurnal variation in nitrogenous constituents of Alfalfa. Agron J. 64:288-291 


\section{TABLES AND FIGURES}

Table 1: Composition and calculated nutrient content of concentrate supplement

Item

Corn, Dent Yellow, ground, \%

Soybean meal, solvent extracted,

$44 \%$ protein, $\%$

Limestone, ground, \%

Calculated nutritional content ${ }^{\mathrm{a}}, \%$

$\mathrm{NE}_{\mathrm{M}}, \mathrm{Mcal} / \mathrm{kg}^{\mathrm{b}}$

$\mathrm{NE}_{\mathrm{G}}, \mathrm{Mcal} / \mathrm{kg}$

$\mathrm{NE}_{\mathrm{L},} \mathrm{Mcal} / \mathrm{kg}$

$\mathrm{CP}, \%$

$\mathrm{Ca}, \%$

$\mathrm{P}, \%$

aalues based on National Research Council, 2001, Nutrient Requirements of Dairy Cattle

${ }^{b} \mathrm{NE}_{\mathrm{M}}=$ net energy for maintenance; $\mathrm{NE}_{\mathrm{G}}=$ net energy for gain; $\mathrm{NE}_{\mathrm{L}}=$ net energy for lactation
DM basis

82.60

1.00

0.35 
Table 2: Weekly mean maximum and minimum temperatures and total precipitation during the experimental periods

\begin{tabular}{|c|c|c|c|}
\hline$\underline{\text { Week }}^{\mathrm{a}}$ & Maximum $\left({ }^{\circ} \mathrm{C}\right)$ & Minimum $\left({ }^{\circ} \mathrm{C}\right)$ & Precipitation $(\mathrm{mm})$ \\
\hline $5 / 05-5 / 11$ & 27.1 & 13.2 & 10.2 \\
\hline $5 / 12-5 / 18$ & 24.0 & 10.7 & 18.5 \\
\hline $5 / 19-5 / 25$ & 22.1 & 13.5 & 99.1 \\
\hline $5 / 26-6 / 01$ & 22.4 & 11.7 & 17.5 \\
\hline $6 / 02-6 / 08$ & 23.4 & 10.7 & 27.9 \\
\hline $6 / 09-6 / 15$ & 29.8 & 18.5 & 30.0 \\
\hline $6 / 16-6 / 22$ & 27.2 & 17.2 & 23.8 \\
\hline $6 / 23-6 / 29$ & 27.3 & 17.9 & 27.7 \\
\hline $6 / 30-7 / 06$ & 26.5 & 14.8 & 20.3 \\
\hline $7 / 07-7 / 13$ & 27.3 & 15.7 & 27.2 \\
\hline $7 / 14-7 / 20$ & 25.5 & 16.3 & 10.1 \\
\hline $7 / 21-7 / 27$ & 25.0 & 13.9 & 7.4 \\
\hline $7 / 28-8 / 03$ & 27.3 & 18.8 & 43.7 \\
\hline $8 / 04-8 / 10$ & 26.7 & 17.9 & 14.2 \\
\hline $8 / 11-8 / 17$ & 25.2 & 14.5 & 13.2 \\
\hline $8 / 18-8 / 24$ & 23.9 & 14.6 & 17.0 \\
\hline $8 / 25-8 / 31$ & 26.1 & 15.9 & 1.8 \\
\hline $9 / 01-9 / 07$ & 26.4 & 15.7 & 2.0 \\
\hline
\end{tabular}

${ }^{a}$ Week: Week $5 / 12-5 / 25=P 1$, Week 6/30 $-7 / 13=$ P2, Week 8/18 $-8 / 29=$ P3 
Table 3: Influence of sward height on botanical composition of forage

Sward height

\begin{tabular}{lrrrr} 
Variable & Low & High & sem $^{1}$ & Significance $^{2}$ \\
Sward height, cm & 6.0 & 9.9 & & \\
$\begin{array}{l}\text { Mean SSH } \\
\text {, cm }\end{array}$ & 6.5 & 11.1 & & \\
$\begin{array}{l}\text { Herbage mass, } \\
\text { Kg DM/ha }\end{array}$ & 1723.0 & 2617.0 & & \\
$\begin{array}{l}\text { Herbage growth rate } \\
\text { Kg DM/ha/d }\end{array}$ & 57.5 & 43.8 & 3.57 & $*$ \\
$\begin{array}{l}\text { Grass, \% } \\
\text { Legume, \% }\end{array}$ & 62.7 & 47.6 & 7.26 & $* *$ \\
Weeds, \% & 6.9 & 3.9 & 1.79 & + \\
Dead, \% & 12.7 & 9.1 & 1.71 & $\dagger$ \\
\hline
\end{tabular}

${ }^{1} \mathrm{n}=12$

$2 * * *=P<0.001 ; * *=P<0.01 ; * P<0.05 ; \dagger=P<0.10$

${ }^{3} \mathrm{SSH}=$ estimated sward surface height using Hill Farming Research Organization sward stick

${ }^{4}$ Herbage growth rate $=$ growth rate of pasture over the experimental periods 
Table 4: Influence of period on botanical composition of forage

\begin{tabular}{|c|c|c|c|c|c|}
\hline \multirow[b]{2}{*}{ Variable } & \multicolumn{3}{|c|}{ Period $^{1}$} & \multirow[b]{2}{*}{$\mathrm{sem}^{2}$} & \multirow[b]{2}{*}{ Significance ${ }^{3}$} \\
\hline & 1 & 2 & 3 & & \\
\hline Mean $\mathrm{SH}, \mathrm{cm}$ & 9.4 & 8.2 & 8.1 & & \\
\hline $\begin{array}{l}\text { Herbage grow } \\
\mathrm{Kg} / \mathrm{ha} / \mathrm{d}\end{array}$ & $63.2^{a}$ & $56.4^{b}$ & $32.4^{c}$ & 4.80 & $* *$ \\
\hline Grass, \% & $55.7^{a}$ & $60.3^{a}$ & $49.4^{b}$ & 4.68 & $\dagger$ \\
\hline Legume, \% & 3.9 & 7.2 & 5.0 & 1.86 & NS \\
\hline Weeds, \% & 8.1 & 12.0 & 12.6 & 2.24 & NS \\
\hline Dead, \% & $32.3^{\mathrm{a}}$ & $20.5^{b}$ & $33.0^{\mathrm{a}}$ & 4.44 & $* *$ \\
\hline
\end{tabular}

${ }^{1}$ Period: 1 = May, 2 = June/July, 3 = August

${ }^{2} \mathrm{n}=8$

$3 * *=P<0.01 ; \dagger=P<0.10 ; \mathrm{NS}=$ non significance

${ }^{4}$ Herbage growth rate $=$ growth rate of pasture over the experimental periods

$a, b, c$ Within a row, means lacking a common superscript differ at $P<0.05$ 
Table 5: Influence of sward height on chemical composition of forage

Sward height

\begin{tabular}{|c|c|c|c|c|}
\hline Variable & Low & High & sem $^{1}$ & Significance ${ }^{2}$ \\
\hline Sward height, cm & 6.0 & 9.9 & & \\
\hline $\mathrm{NDF}^{3}, \%$ & 59.8 & 64.4 & 1.54 & $*$ \\
\hline$A D F, \%$ & 31.9 & 35.2 & 1.39 & $\dagger$ \\
\hline $\mathrm{CP}, \%$ & 16.5 & 12.8 & 0.70 & $* *$ \\
\hline $\mathrm{APL}, \%$ & 3.7 & 3.6 & 0.25 & NS \\
\hline
\end{tabular}


Table 6: Influence of period on chemical composition of forage

\begin{tabular}{|c|c|c|c|c|c|}
\hline \multirow[b]{2}{*}{ Variable } & \multicolumn{3}{|c|}{ Period $^{1}$} & \multirow[b]{2}{*}{$\mathrm{sem}^{2}$} & \multirow[b]{2}{*}{ Significance } \\
\hline & 1 & 2 & 3 & & \\
\hline$N^{\prime} F^{4}, \%$ & 62.0 & 62.0 & 62.4 & 1.13 & NS \\
\hline$A D F, \%$ & $31.9^{b}$ & $34.1^{\mathrm{a}}$ & $34.6^{a}$ & 0.89 & $* * *$ \\
\hline $\mathrm{CP}, \%$ & $14.9^{\mathrm{a}}$ & $13.9^{b}$ & $15.1^{\mathrm{a}}$ & 0.32 & $* *$ \\
\hline APL, \% & 3.7 & 3.7 & 3.6 & 0.36 & NS \\
\hline
\end{tabular}

${ }^{1}$ Period: $1=$ May, 2 = June/July, $3=$ August

${ }^{2} \mathrm{n}=8$

${ }^{3} \mathrm{NS}=$ non significance; $* * *=P<0.001 ; * *=P<0.01$

${ }^{4} \mathrm{NDF}=$ neutral detergent fiber; $\mathrm{ADF}=$ acid detergent fiber; $\mathrm{CP}=$ crude protein; $\mathrm{APL}=$ alkaline peroxide lignin

a,b Within a row, means lacking a common superscript differ at $P<0.01$ 


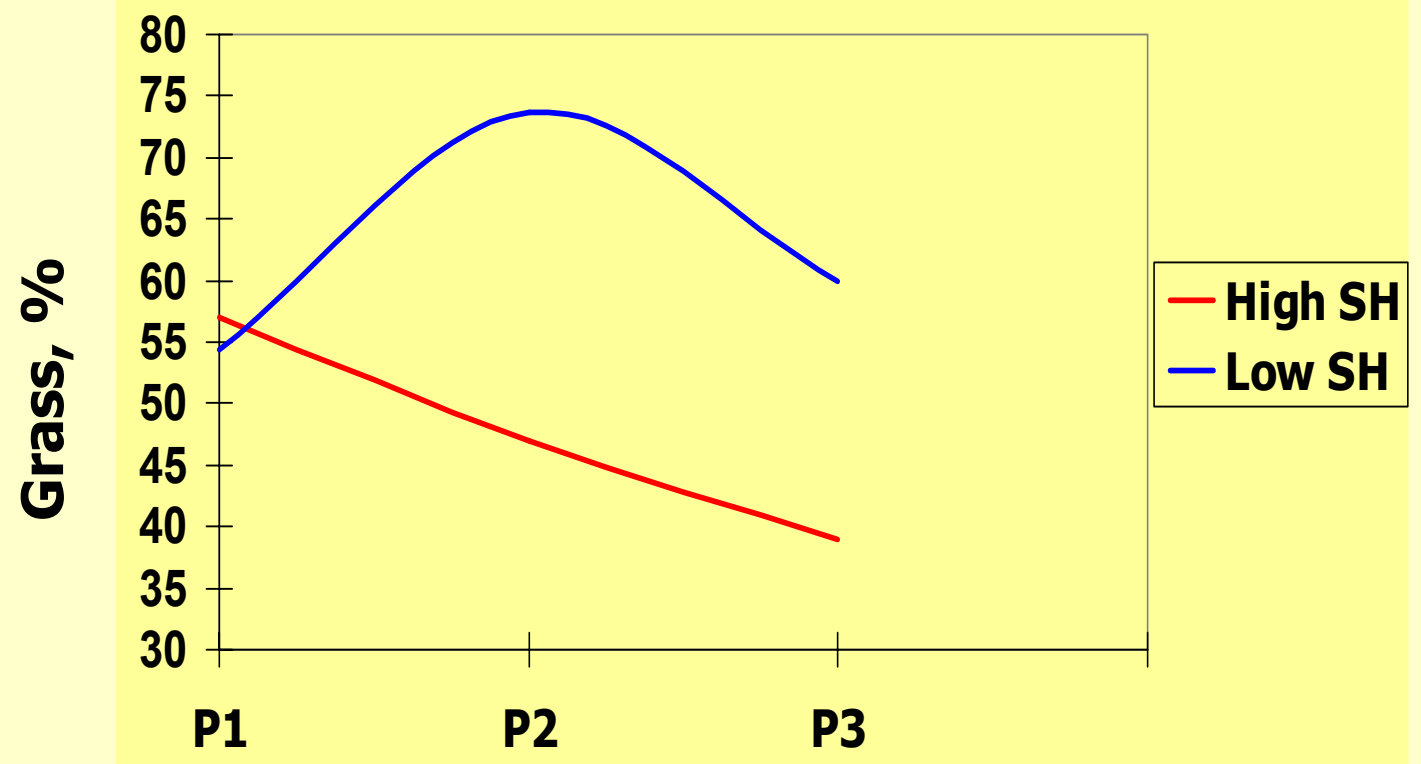

Figure 1: Influence of sward height and period on proportion of grass High $\mathrm{SH}=$ high sward height; Low SH = low sward height; Sward height $\mathrm{x}$ Period interaction $(P<0.10)$ 


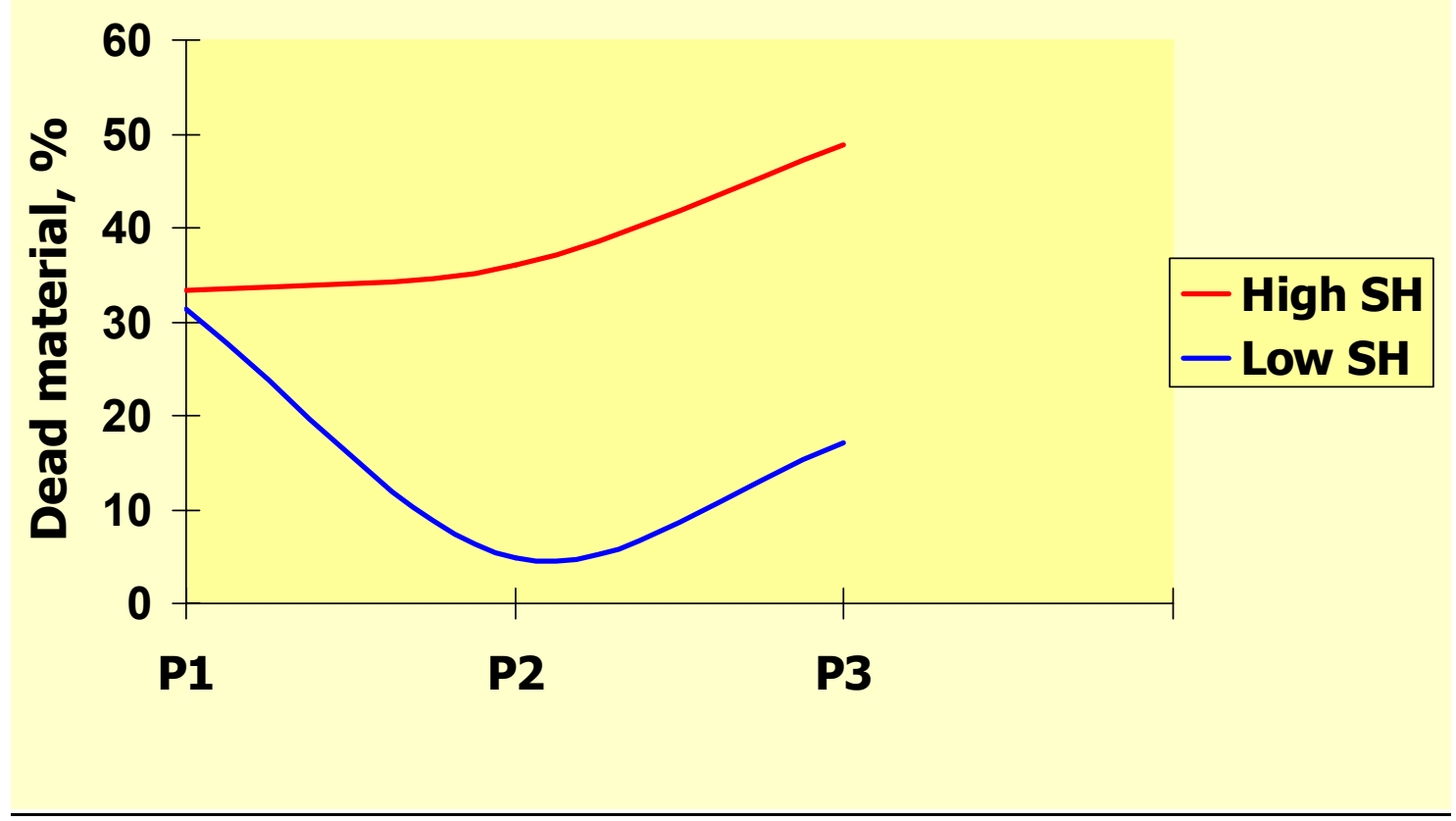

Figure 2: Influence of sward height and period on proportion of dead material High $\mathrm{SH}$ = high sward height; Low SH = low sward height; Sward height $\mathrm{x}$ Period interaction $(P<0.01)$ 


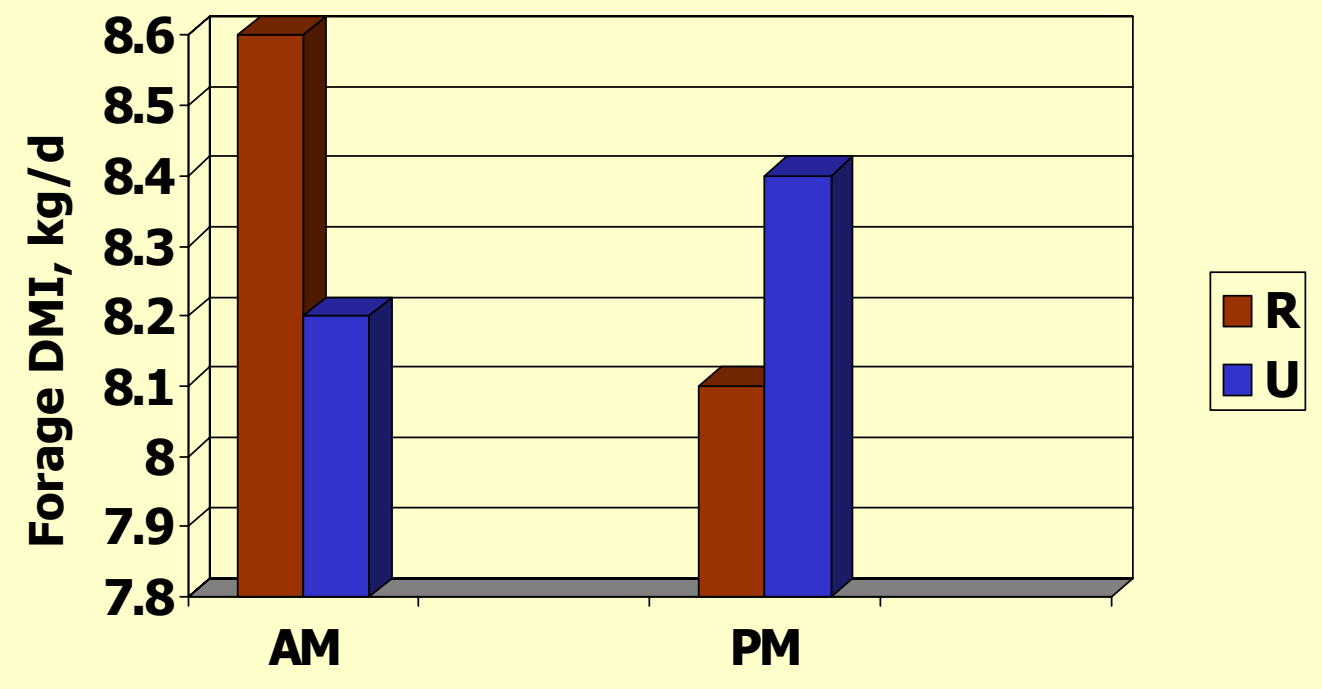

Figure 3: Influence of supplement feeding time and grazing time management on forage DMI of cows

$\mathrm{R}=$ Restricted grazing (12 h/d); U = Unrestricted grazing (24 h/d); Supplement feeding time $x$ Grazing time management interaction $(P<0.05)$ 


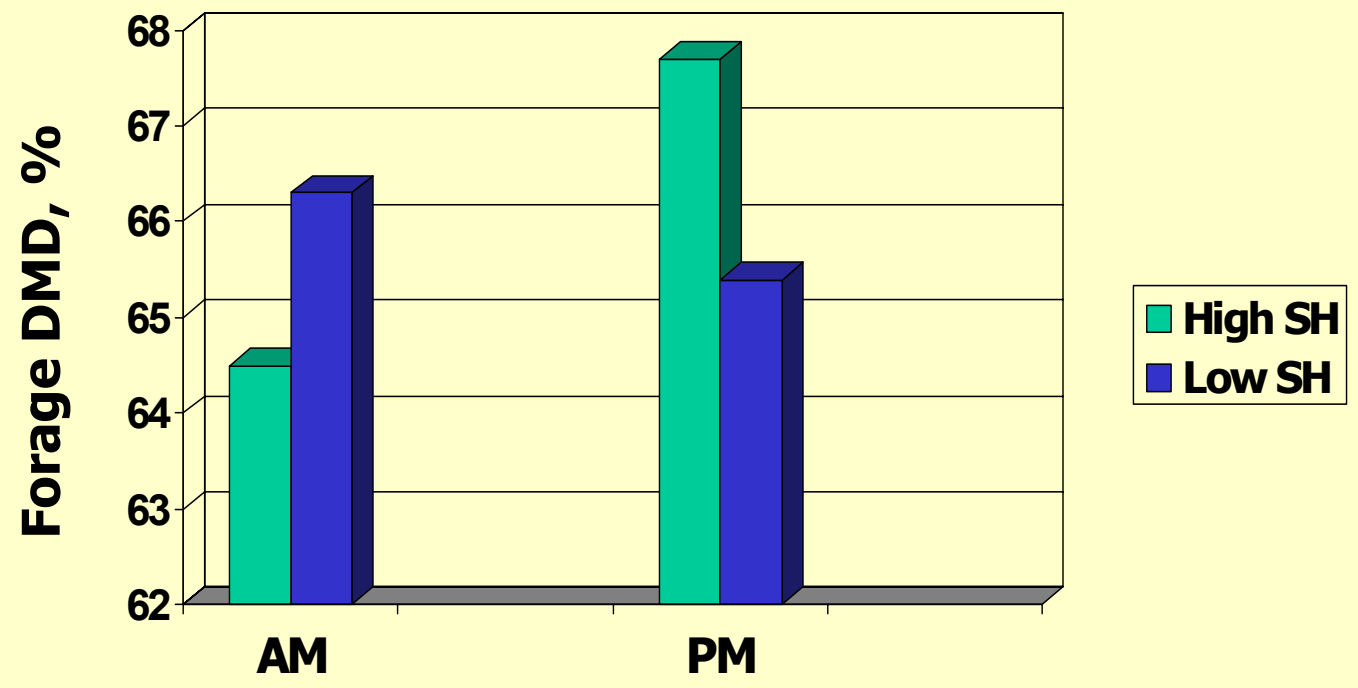

Figure 4: Influence of sward height and supplement feeding time on forage DM digestibility of cows

High $\mathrm{SH}=$ high sward height; Low $\mathrm{SH}=$ low sward height; Sward height $\mathrm{x}$ Supplement feeding time interaction $(P<0.05)$ 


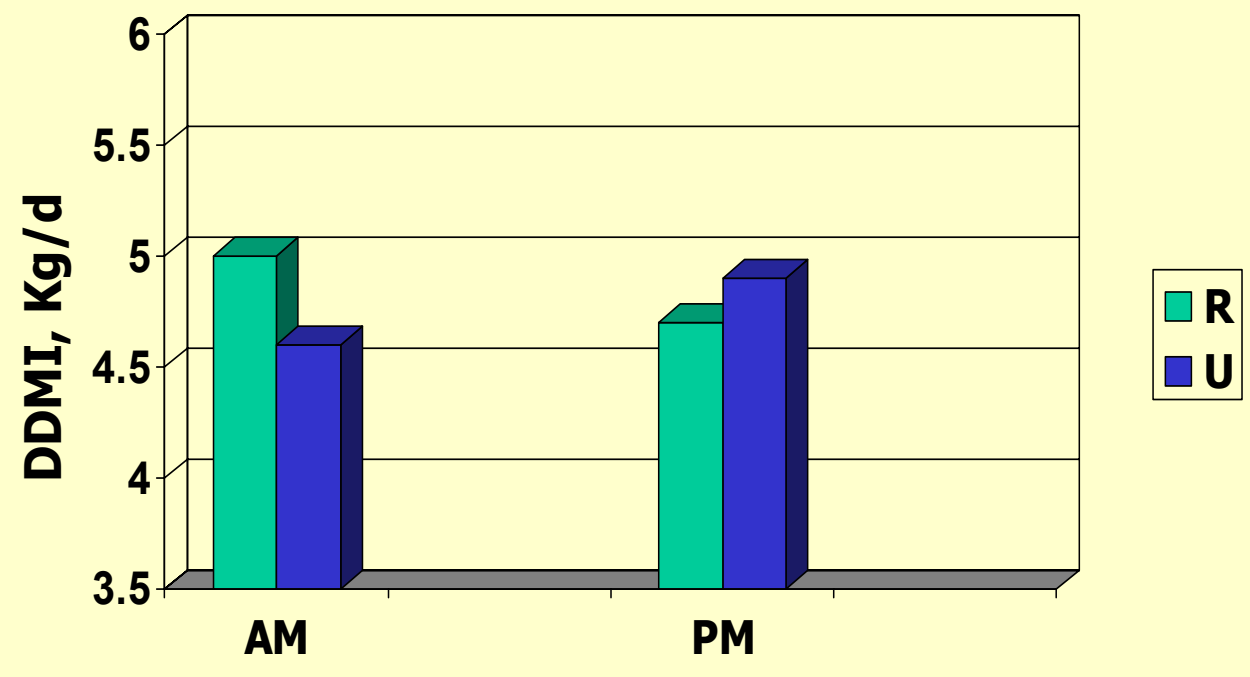

Figure 5: Influence of supplement feeding time and grazing time management on forage digestible DMI of cows

$\mathrm{R}=$ Restricted grazing (12 h/d); U = Unrestricted grazing (24 h/d); Supplement feeding time $\times$ Grazing time management interaction $(P<0.10)$ DDMI $=$ forage digestible DMI 


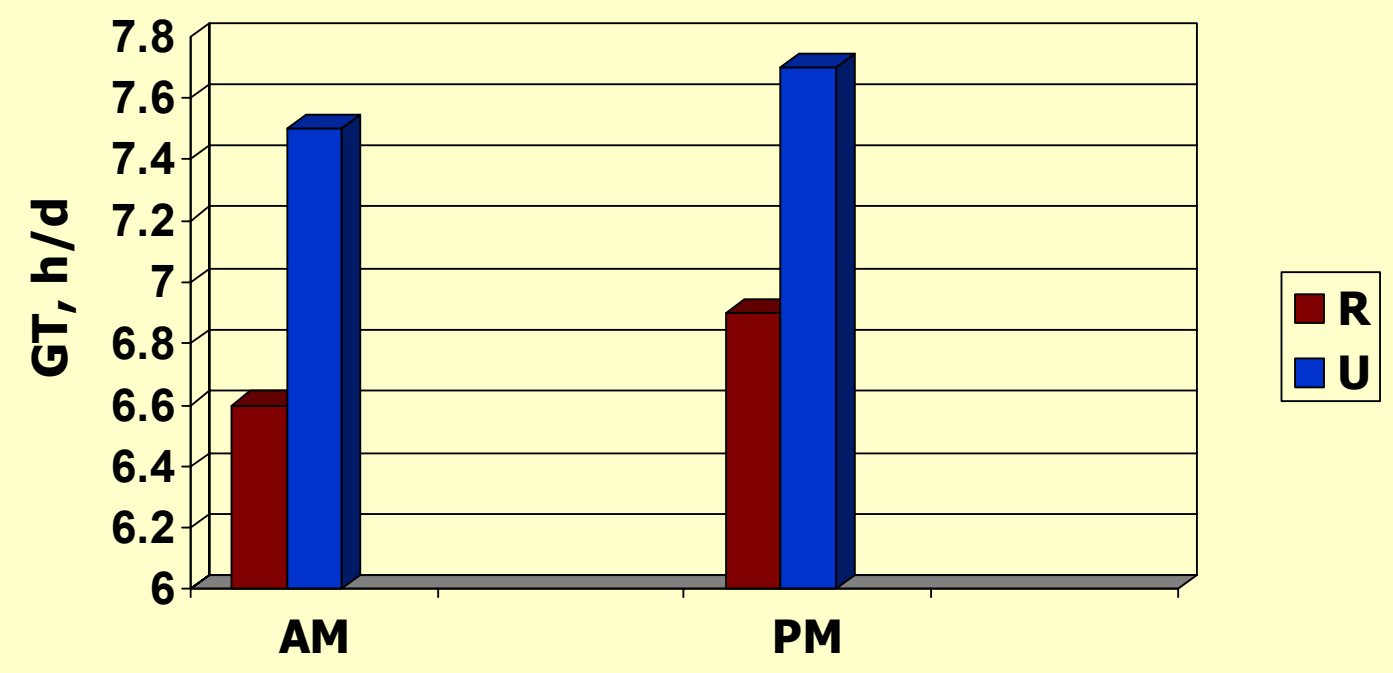

Figure 6: Influence of supplement feeding time and grazing time management on grazing time of cows

$\mathrm{R}=$ Restricted grazing $(12 \mathrm{~h} / \mathrm{d}) ; \mathrm{U}=$ Unrestricted grazing $(24 \mathrm{~h} / \mathrm{d})$; Supplement feeding time $x$ Grazing time management interaction $(P<0.10)$ 


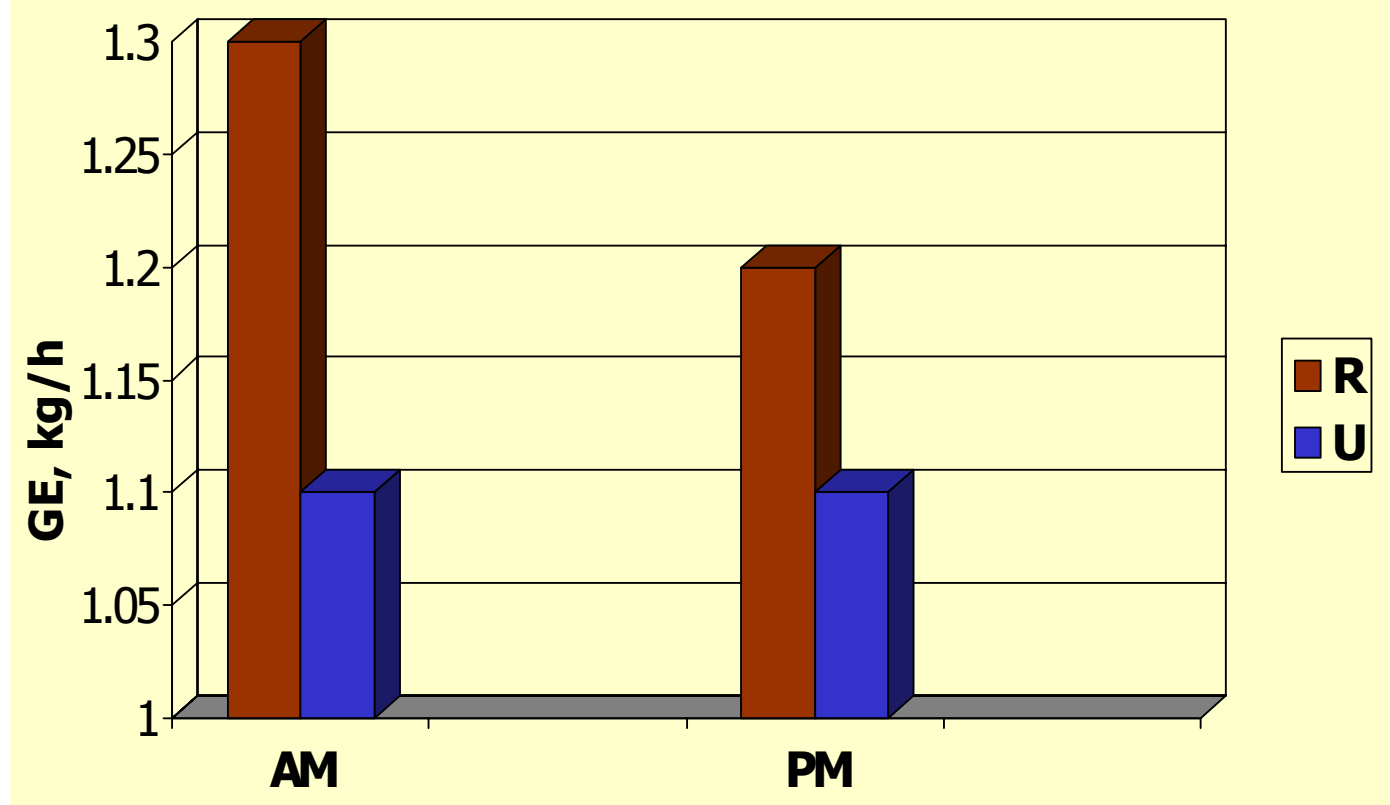

Figure 7: Influence of supplement feeding time and grazing time management on grazing efficiency of cows

$\mathrm{R}=$ Restricted grazing (12 h/d); $\mathrm{U}=$ Unrestricted grazing (24 h/d); Supplement feeding time $x$ Grazing time management interaction $(P<0.01)$ 


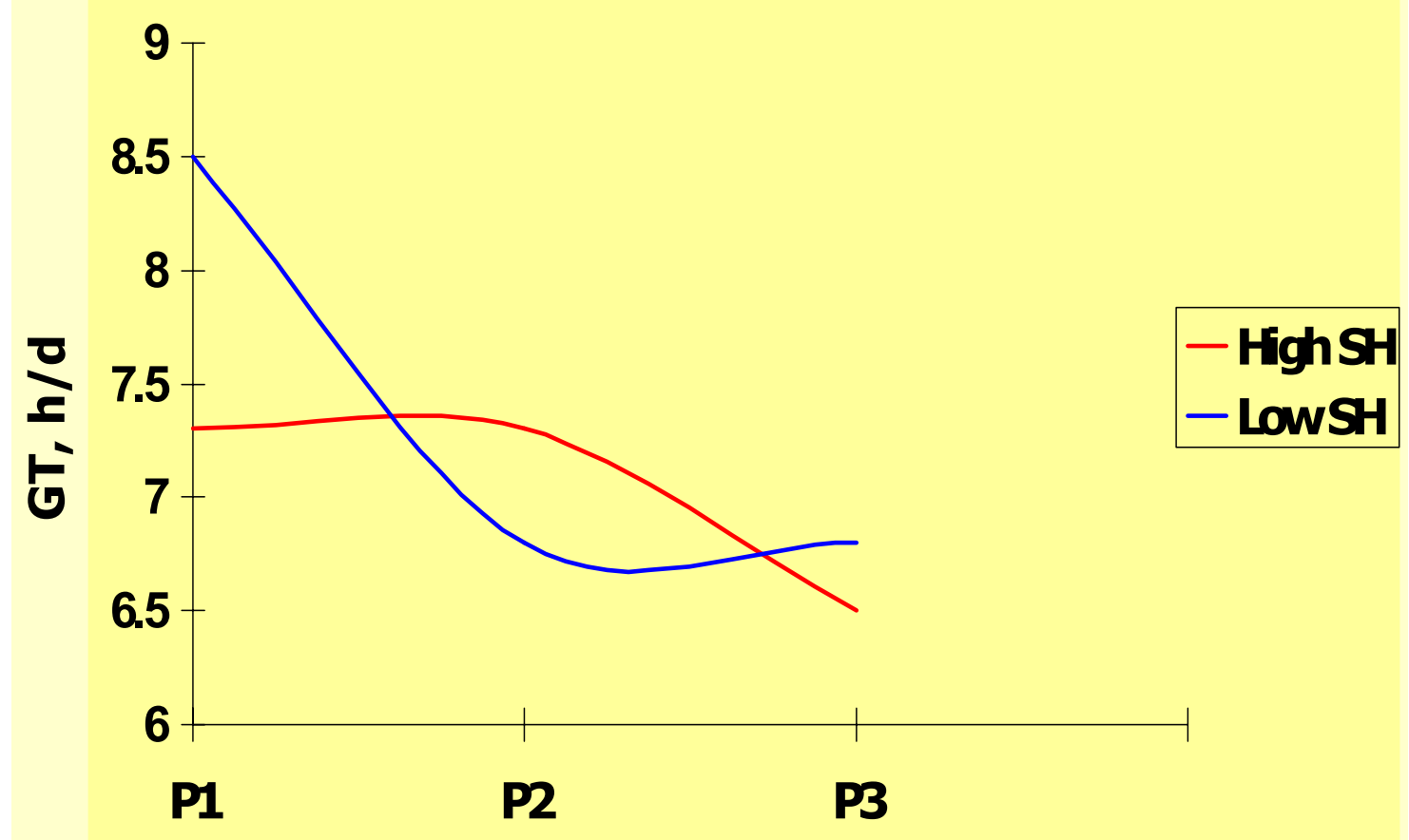

Figure 8: Influence of sward height and period on grazing time of cows $\mathrm{P} 1=$ May, $\mathrm{P} 2=$ June/July, $\mathrm{P} 3=$ August; Sward height $\mathrm{x}$ Period interaction $(P<$ $0.05)$

High SH = high sward height; Low SH = low sward height 


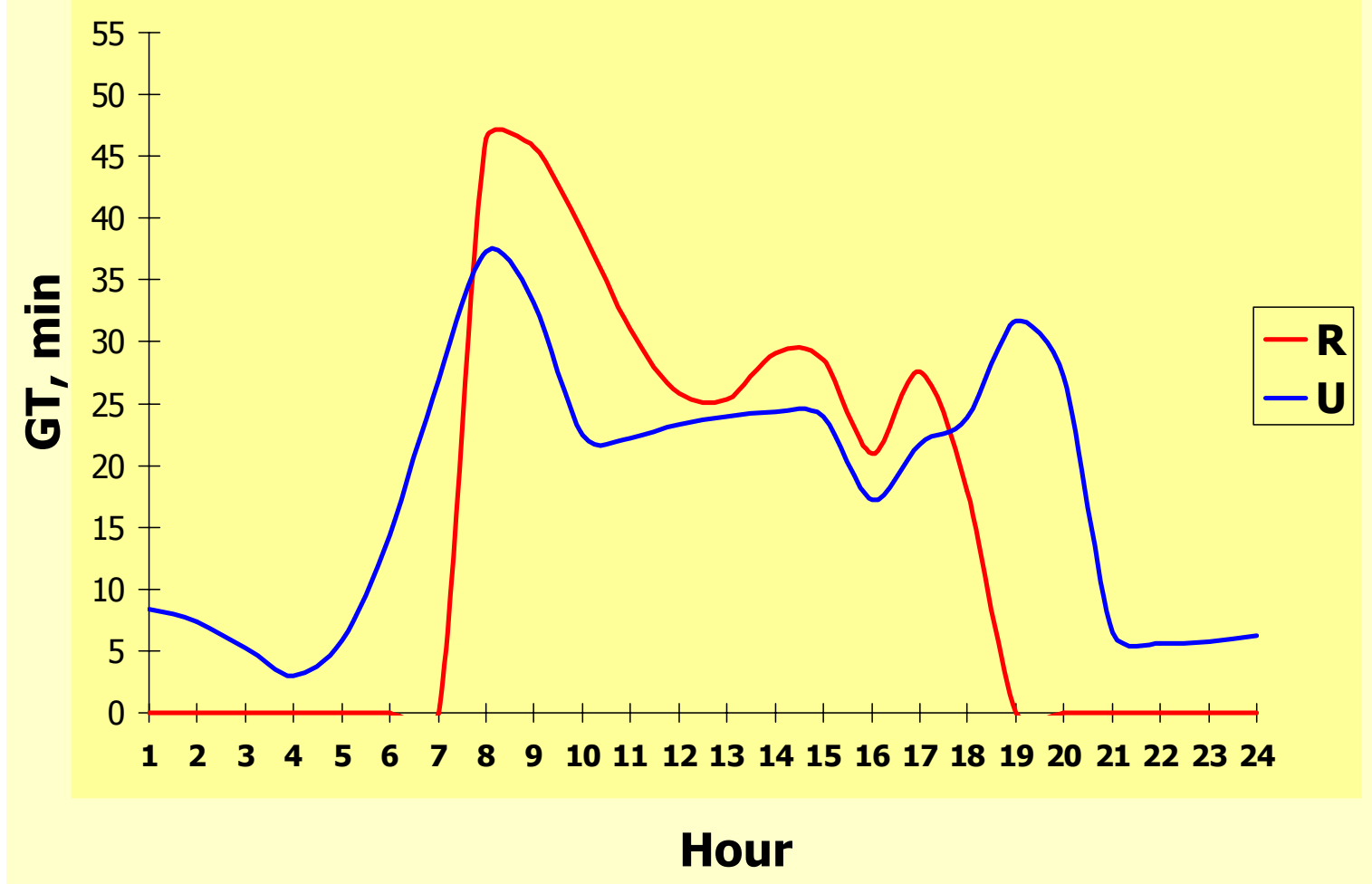

Figure 9: Influence of grazing time management and hour on grazing pattern of cows

$\mathrm{R}=$ Restricted grazing $(12 \mathrm{~h} / \mathrm{d}) ; \mathrm{U}=$ Unrestricted $(24 \mathrm{~h} / \mathrm{d}) ;$ Grazing time management $x$ Grazing hour interaction $(P<0.10)$ 


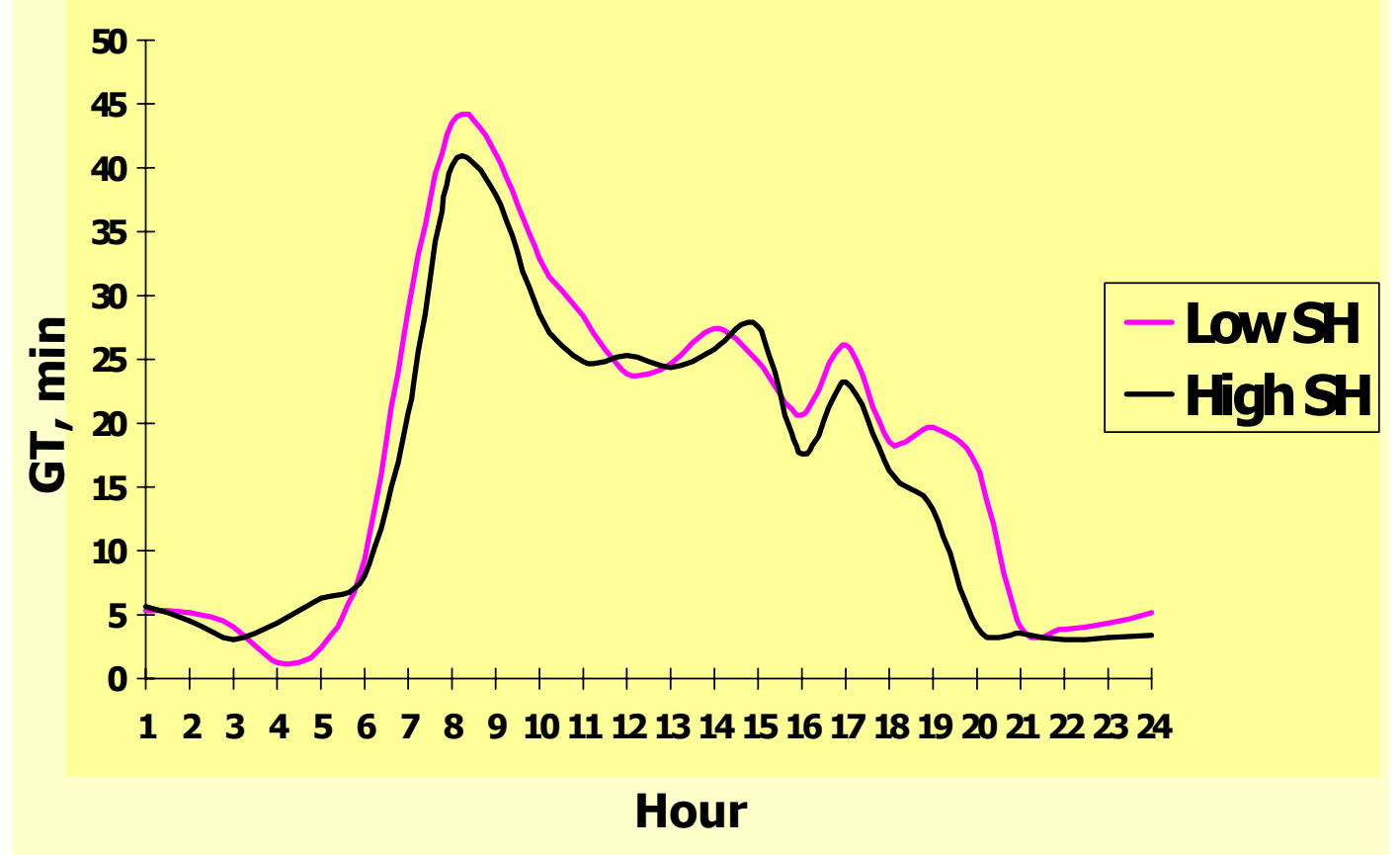

Figure 10: Influence of sward height and hour on grazing pattern of cows Low $\mathrm{SH}=$ low sward height; High $\mathrm{SH}=$ high sward height; Sward height $\mathrm{x}$ Grazing hour interaction $(P>0.10)$ 


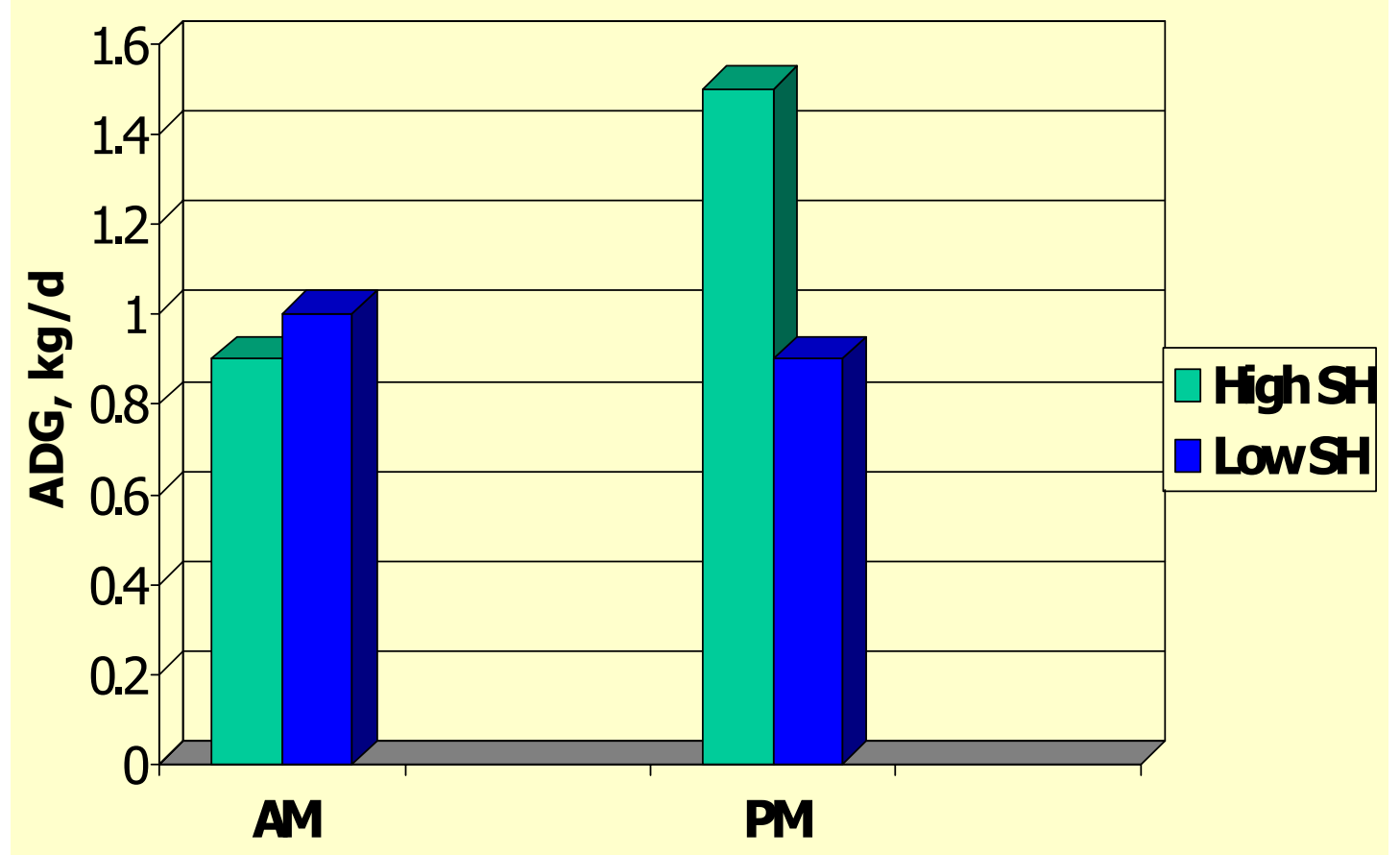

Figure 11: Influence of sward height and supplement feeding time on cow gain High $\mathrm{SH}=$ high sward height; Low $\mathrm{SH}=$ low sward height; Sward height $\mathrm{x}$ Supplement feeding time interaction $(P<0.10)$ 


\section{APPENDIX}

Table 1: Summary of animal responses to experimental treatments

Forage Total Forage Forage $G^{\mathrm{a}} \mathrm{GE}^{\mathrm{b}}$ ADG ADG

DMI DMI DMD DDMI cows calves

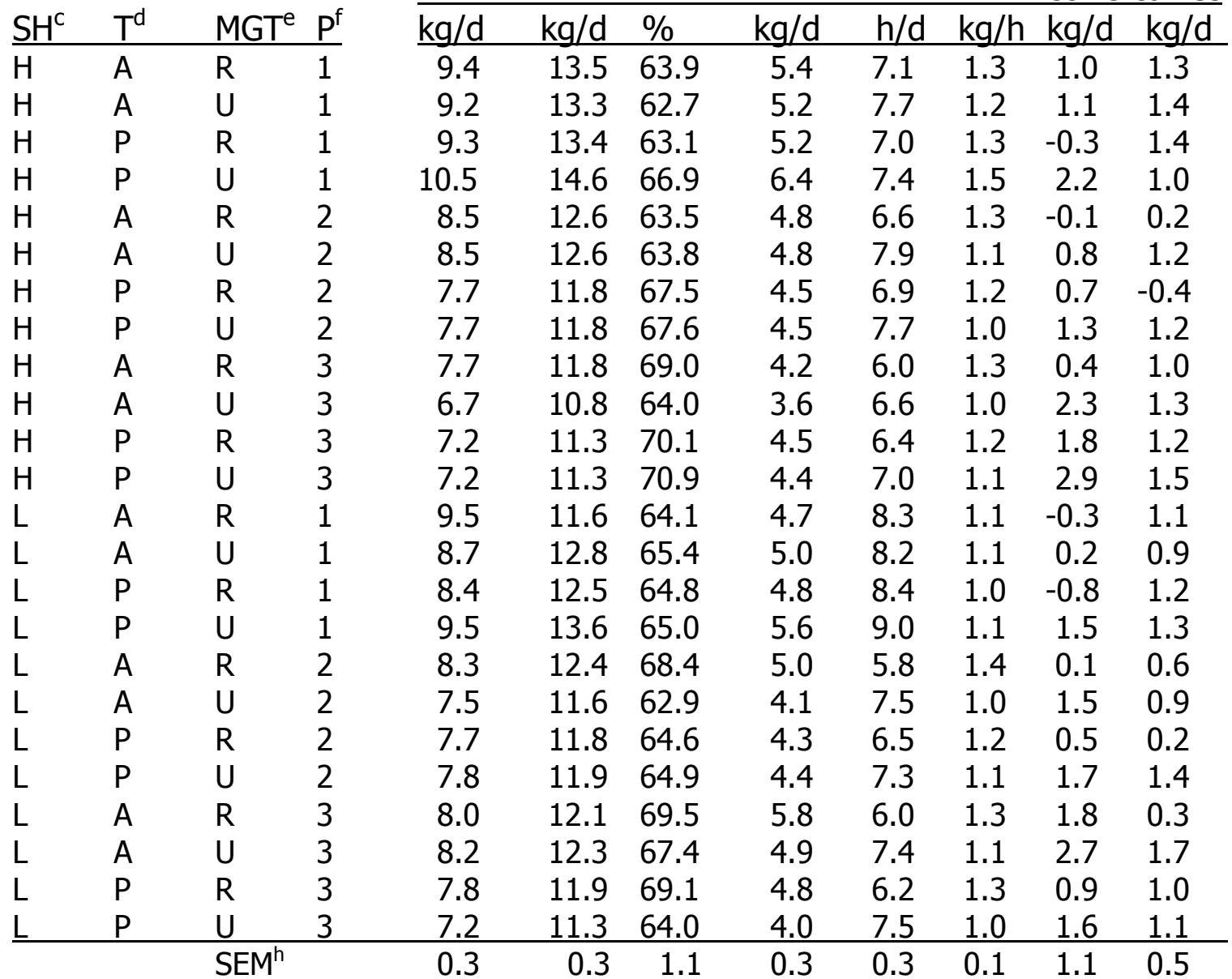

Significance level:

$\begin{array}{lllllllll}\text { SHxT } & \text { NS } & \text { NS } & * & \text { NS } & \text { NS } & \text { NS } & \dagger & \text { NS } \\ \text { SHXMGT } & \text { NS } & \text { NS } & \text { NS } & \text { NS } & \text { NS } & \text { NS } & \text { NS } & \text { NS } \\ \text { SHxP } & \text { NS } & \text { NS } & \text { NS } & \text { NS } & * & * & \text { NS } & \text { NS } \\ \text { TxMGT } & * & * & \text { NS } & \dagger & \dagger & * * & \text { NS } & \text { NS } \\ \text { TxP } & \text { NS } & \text { NS } & \text { NS } & \text { NS } & \text { NS } & \text { NS } & \text { NS } & \text { NS } \\ \text { MGTxP } & \text { NS } & \text { NS } & \text { NS } & \text { NS } & \text { NS } & \dagger & \text { NS } & \text { NS }\end{array}$

${ }^{\mathrm{a}} \mathrm{GT}=$ grazing time $(\mathrm{h} / \mathrm{d})$

${ }^{\mathrm{b}} \mathrm{GE}=$ grazing efficiency $(\mathrm{kg} \mathrm{DM} / \mathrm{h}$ of $\mathrm{GT})$

${ }^{\mathrm{C}} \mathrm{SH}=$ sward height $(\mathrm{cm}): \mathrm{H}=$ high $\mathrm{SH}, \mathrm{L}=$ low $\mathrm{SH}$

${ }^{\mathrm{d}} \mathrm{T}=$ supplement feeding time: $\mathrm{A}=\mathrm{AM}(0700 \mathrm{~h}) ; \mathrm{P}=\mathrm{PM}(1800 \mathrm{~h})$

${ }^{\mathrm{e}} \mathrm{MGT}=$ management: $\mathrm{R}=$ restricted grazing $(12 \mathrm{~h} / \mathrm{d}) ; \mathrm{U}=$ unrestricted grazing

$\mathrm{f}_{\mathrm{P}}=$ period: $\mathrm{P} 1$ = May; $\mathrm{P} 2$ = June/July; $\mathrm{P} 3=$ August

${ }^{\mathrm{h}} \mathrm{n}=4$

iNS $=$ non significance: $* *=P<0.01 ; *=P<0.05 ; \dagger=P<0.10$ 
Table 2: Influence of sward height on animal performance

Sward height

\begin{tabular}{|c|c|c|c|c|}
\hline Variable & Low & High & sem $^{1}$ & Significance $^{2}$ \\
\hline Sward height, cm & 6.0 & 9.9 & & \\
\hline Forage DMI, kg/d & 8.2 & 8.3 & 0.26 & NS \\
\hline Total DMI, kg/d & 12.3 & 12.4 & 0.26 & NS \\
\hline Forage DMD, \% & 65.8 & 66.1 & 1.72 & NS \\
\hline Forage dig DMI, $\mathrm{kg} / \mathrm{d}$ & 4.8 & 4.8 & 0.25 & NS \\
\hline Total dig DMI, kg/d & 8.6 & 8.6 & 0.25 & NS \\
\hline Grazing time, h/d & 7.3 & 7.0 & 0.30 & NS \\
\hline Grazing efficiency, kg/h & 1.2 & 1.2 & 0.06 & NS \\
\hline Digestible NDF, \% & 65.9 & 66.5 & 1.70 & NS \\
\hline Digestible ADF, \% & 55.3 & 58.0 & 1.71 & NS \\
\hline Digestible $\mathrm{CP}, \%$ & 77.2 & 74.0 & 1.46 & $\dagger$ \\
\hline Forage DMI/kg BW, g/d & 13.2 & 12.8 & 0.38 & NS \\
\hline Total DMI/kg BW, g/d & 19.6 & 19.0 & 0.39 & NS \\
\hline ADG (cows), kg/d & 0.9 & 1.2 & 0.32 & NS \\
\hline ADG (calves), kg/d & 1.0 & 1.0 & 0.17 & NS \\
\hline
\end{tabular}


Table 3: Influence of feeding time on animal performance Feeding time ${ }^{1}$

\begin{tabular}{|c|c|c|c|c|}
\hline Variable & $A M$ & PM & $\mathrm{sem}^{2}$ & Significance $^{3}$ \\
\hline Forage DMI, kg/d & 8.4 & 8.2 & 0.20 & NS \\
\hline Total DMI, kg/d & 12.4 & 12.2 & 0.20 & NS \\
\hline Forage DMD, \% & 65.4 & 66.6 & 0.81 & NS \\
\hline Forage dig DMI, kg/d & 4.8 & 4.8 & 0.18 & NS \\
\hline Total dig DMI, kg/d & 8.6 & 8.6 & 0.18 & NS \\
\hline Grazing time, hr/d & 7.1 & 7.3 & 0.24 & NS \\
\hline Grazing efficiency, kg/hr & 1.2 & 1.2 & 0.05 & NS \\
\hline Digestible NDF, \% & 65.6 & 66.9 & 0.67 & NS \\
\hline Digestible ADF, \% & 56.0 & 57.2 & 0.92 & NS \\
\hline Digestible $\mathrm{CP}, \%$ & 74.9 & 76.3 & 0.50 & $\dagger$ \\
\hline Forage DMI/kg BW, g/d & 13.0 & 13.0 & 0.66 & NS \\
\hline Total DMI/kg BW, g/d & 19.3 & 19.4 & 0.89 & NS \\
\hline ADG (cows), kg/d & 1.0 & 1.2 & 0.28 & NS \\
\hline ADG (calves), kg/d & 1.0 & 1.0 & 0.12 & NS \\
\hline
\end{tabular}


Table 4: Influence of management on animal performance

\begin{tabular}{lcccc} 
& \multicolumn{3}{c}{ Management $^{1}$} & \\
\cline { 2 - 4 } Variable & $\mathrm{R}$ & $\mathrm{U}$ & $\mathrm{sem}^{2}$ & Significance $^{3}$ \\
\hline Forage DMI, kg/d & 8.3 & 8.3 & 0.20 & $\mathrm{NS}$ \\
Total DMI, kg/d & 12.4 & 12.4 & 0.20 & $\mathrm{NS}$ \\
Forage DMD, \% & 66.5 & 65.4 & 0.81 & $\mathrm{NS}$ \\
Forage dig DMI, kg/d & 4.8 & 4.7 & 0.18 & $\mathrm{NS}$ \\
Total dig DMI, kg/d & 8.6 & 8.5 & 0.18 & $\mathrm{NS}$ \\
Grazing time, hr/d & 6.8 & 7.6 & 0.24 & $* *$ \\
Grazing efficiency, kg/hr & 1.3 & 1.1 & 0.05 & $*$ \\
Digestible NDF, \% & 66.8 & 65.7 & 0.67 & NS \\
Digestible ADF, \% & 57.3 & 55.9 & 0.92 & NS \\
Digestible CP, \% & 75.5 & 75.6 & 0.50 & NS \\
Forage DMI/kg BW, g/d & 13.0 & 13.0 & 0.66 & NS \\
Total DMI/kg BW, g/d & 19.4 & 19.3 & 0.89 & NS \\
ADG (cows), kg/d & 0.5 & 1.6 & 0.28 & $* * *$ \\
ADG (calves), kg/d & 0.8 & 1.2 & 0.12 & $* * *$ \\
\hline
\end{tabular}

\footnotetext{
${ }^{1} \mathrm{R}=$ restricted grazing $(12 \mathrm{~h} / \mathrm{d}) ; \mathrm{U}=$ unrestricted grazing

${ }^{2} \mathrm{n}=48$

${ }^{3 * * *}=P<0.001 ; * *=P<0.01 ; *=P<0.05 ; \mathrm{NS}=$ non significance
} 
Table 5: Influence of period on animal performance

\section{Period $^{1}$}

\begin{tabular}{lccccc} 
Variable & 1 & 2 & 3 & sem $^{2}$ & Significance $^{3}$ \\
Forage DMI, kg/d & $9.3^{\mathrm{a}}$ & $8.0^{\mathrm{b}}$ & $7.5^{\mathrm{b}}$ & 0.34 & $* * *$ \\
Total DMI, kg/d & $13.4^{\mathrm{a}}$ & $12.1^{\mathrm{b}}$ & $11.6^{\mathrm{b}}$ & 0.34 & $* * *$ \\
Forage DMD, \% & $64.5^{\mathrm{b}}$ & $65.4^{\mathrm{b}}$ & $68.0^{\mathrm{a}}$ & 1.16 & $*$ \\
Forage dig DMI, kg/d & $5.3^{\mathrm{a}}$ & $4.6^{\mathrm{b}}$ & $4.5^{\mathrm{b}}$ & 0.34 & + \\
Total dig DMI, kg/d & $9.1^{\mathrm{a}}$ & $8.4^{\mathrm{b}}$ & $8.3^{\mathrm{b}}$ & 0.34 & + \\
Grazing time, hr/d & $7.9^{\mathrm{a}}$ & $7.0^{\mathrm{b}}$ & $6.6^{\mathrm{b}}$ & 0.29 & $* * *$ \\
Grazing efficiency, kg/hr & $1.2^{2}$ & $1.2^{2}$ & $1.2^{2}$ & 0.07 & $\mathrm{NS}$ \\
Digestible NDF, \% & $65.7^{\mathrm{b}}$ & $64.7^{\mathrm{b}}$ & $68.2^{\mathrm{a}}$ & 1.21 & $*$ \\
Digestible ADF, \% & $56.7^{\mathrm{b}}$ & $54.6^{\mathrm{ab}}$ & $58.6^{\mathrm{a}}$ & 1.69 & + \\
Digestible CP, \% & $72.4^{\mathrm{c}}$ & $76.0^{\mathrm{b}}$ & $78.4^{\mathrm{a}}$ & 0.88 & $* * *$ \\
Forage DMI/kg BW, g/d & $14.7^{\mathrm{a}}$ & $12.3^{\mathrm{b}}$ & $12.0^{\mathrm{b}}$ & 0.62 & $* * *$ \\
Total DMI/kg BW, g/d & $21.2^{\mathrm{a}}$ & $18.4^{\mathrm{b}}$ & $18.4^{\mathrm{b}}$ & 0.64 & $* * *$ \\
ADG (cows), kg/d & $0.6^{\mathrm{b}}$ & $0.8^{\mathrm{b}}$ & $1.8^{\mathrm{a}}$ & 0.39 & $* *$ \\
ADG (calves), kg/d & $1.2^{\mathrm{a}}$ & $0.6^{\mathrm{b}}$ & $1.1^{\mathrm{a}}$ & 0.18 & $*$ \\
\hline & & & & & \\
\hline
\end{tabular}

\footnotetext{
${ }^{1} 1=$ May, 2 = June/July, $3=$ August$$
{ }^{2} \mathrm{n}=32
$$$$
{ }^{3 * * *}=P<0.001 ; * *=P<0.01 ; *=P<0.05 ; \dagger=P<0.10 ; \mathrm{NS}=\text { non }
$$
significance

$\mathrm{a}, \mathrm{b}, \mathrm{c}$ Within a row, means lacking a common superscript differ at $P<0.10$
} 


\section{VITA}

Name:

Ondieki J. Gekara

Date of Birth:

July 19,1961

Parents:

James Gekara

Rebecca Gekara

Wife:

Gladys Ondieki

Children:

Acline, Albert and Annette

Institutions Attended:

Gesiaga Primary School, Kisii, Kenya $1968-1975$

Gesiaga Secondary School, Kisii, Kenya 1976 - 1977

Sameta High School, Kisii, Kenya $1978-1979$

AHITI, Nyahururu, Kenya

$1981-1983$

Barneveld College, Netherlands

$1987-1988$

West Virginia University, Morgantown WV

$1994-1996$

West Virginia University, Morgantown WV

$1996-1999$

Degrees Awarded:

Cert in Animal Health, AHITI -Nyahururu

1983

Dip in Poultry Husbandry \& Feed Milling Tech,

Barneveld College

1988

BS in Agriculture, WVU

MS in Animal and Vet Sciences, WVU

Employment: Ministry of Agriculture and Livestock Development, Kenya

Title:

Technical Officer 